University of Michigan Law School University of Michigan Law School Scholarship Repository

1999

\title{
Sincere and Strategic Voting Norms on Multimember Courts
}

Evan H. Caminker

University of Michigan Law School, caminker@umich.edu

Available at: https://repository.law.umich.edu/articles/74

Follow this and additional works at: https://repository.law.umich.edu/articles

Part of the Courts Commons, and the Supreme Court of the United States Commons

Recommended Citation

Caminker, Evan H. "Sincere and Strategic Voting Norms on Multimember Courts." Mich. L. Rev. 97, no. 8 (1999): 2297-380.

This Article is brought to you for free and open access by the Faculty Scholarship at University of Michigan Law School Scholarship Repository. It has been accepted for inclusion in Articles by an authorized administrator of University of Michigan Law School Scholarship Repository. For more information, please contact mlaw.repository@umich.edu. 


\title{
SINCERE AND STRATEGIC VOTING NORMS ON MULTIMEMBER COURTS
}

\author{
Evan H. Caminker* \\ TABle of Contents
}

INTRODUCTION ................................. 2298

I. Sincere Decisionmaking in Solo and

Collegial Adjudication .................... 2303

A. Solo Judgment Formation ................. 2304

1. Relational Judgment Criteria and

Interconnecting Cases ................. 2304

2. Sophisticated Consideration of Nonjudicial Actors' Views ......................... 2308

B. Sincere Judgment Formation on a Multimember Court ....................................

II. Opportunities and InCENTIVES For Strategic Voting on a Multimember Court .............

A. Assessing the Magnitude of Perceived Error of the Court's Output ...........................

B. Strategic Voting to Improve the Form of

Collective Decisions .

1. Formation of Majority-Disposition

Coalitions ............................. 2315

2. Formation of Majority-Opinion Coalitions . 2317

3. Formation of Supermajority Coalitions ..... 2321

C. Strategic Voting to Improve the Content of

Legal Rules ............................ 2323

1. Unilateral Strategic Voting to Influence a

Discrete Legal Rule ..................... $\quad 2324$

2. Bilateral Vote Trading................... 2331

III. Normative Constraints on Strategic

VOTING .....................................

* Professor of Law, University of Michigan Law School. B.A. 1983, UCLA; J.D. 1986, Yale. - Ed. For helpful comments on earlier drafts or the ideas contained herein, I gratefully acknowledge Omri Ben-Shahar, Hanoch Dagan, Rich Friedman, Tracey George, Mitu Gulati, Edward Hartnett, Rick Hasen, Lewis Kornhauser, Bill Rubenstein, Jane Schacter, Michael Small, Max Stearns, Stephen Yeazell, and a large number of colleagues and friends on the faculties of the Michigan, UCLA, and USC law schools who participated in enlightening workshops. I also thank Adam Cox, Goriune Dudukgian, and Christopher Rose for extremely valuable research assistance. 
A. Solo Adjudication Norms in a Collegial

Context .................................. 2334

1. Litigant-Focused Constraints ............. 2335

2. Reasoned Justification Constraints......... 2344

3. Judicial Lawmaking Constraints........... 2354

B. Accuracy Through Pure Redundancy ......... 2362

1. The Redundancy Theorem ............... 2362

2. The Redundancy Theorem Applied ....... 2363

3. Questioning the Redundancy Premise: The Propriety of Intensity Weighting .......... 2367

C. Accuracy Through Deliberative Reasoning ..... 2372

D. Moderation and Stability Through a

Competitive Equilibrium .................... 2375

IV. Conclusion ................................ 2379

\section{INTRODUCTION}

In appellate adjudication, decisions are rendered by a multimember court as a collective entity, not by individual judges. Yet legal scholars have only just begun to explore the formal and informal processes by which individual votes are transformed into a collective judgment. ${ }^{1}$ In particular, they have paid insufficient attention to the ways in which the vote of each individual judge is influenced by the views of her colleagues on a multimember court.

In recent years, a growing number of political scientists exploring judicial behavior have modelled this aspect of adjudication. Building on Walter Murphy's pathbreaking work thirty-five years ago, ${ }^{2}$ these scholars view judges as rationally seeking, within their

1. Max Stearns calls this the study of "constitutional process." Maxwell L. STEARNS, Constrtutional Process: A Soctal Choice Analysis of Supreme Court Decision MAKING 19 (forthcoming 1999) (manuscript on file with author). Some scholars have addressed the question of whether, in a case raising two or more discrete legal issues, individual judges' votes ought to be aggregated into a collective judgment through an "issue-by-issue" or "outcome-by-outcome" headcount. Under certain scenarios, the method of aggregation will determine who prevails. See, e.g., Colloquium, Appellate Court Voting Rules, 49 VAND. L. REv. 993 (1996) (containing several articles discussing issue); Lewis A. Kornhauser \& Lawrence G. Sager, The One and the Many: Adjudication in Collegial Courts, $81 \mathrm{CAL}$. L. REv. 1, 10-17 (1993) (discussing issue and citing other scholarship). Some scholars have considered the applicability of Arrow's theorem to multimember courts, evaluating the extent and significance of potential voting "cycles" over time. See, e.g., Frank E. Easterbrook, Ways of Criticizing the Court, 95 HARv. L. REv. 802 (1982); Maxwell L. Stearns, The Misguided Renaissance of Social Choice, 103 Y ALE L.J. 1219 (1994). Some scholars have considered the problems associated with judicial decisions in which no single majority opinion supports the disposition of the case. See, e.g., John F. Davis \& William L. Reynolds, Juridical Cripples: Plurality Opinions in the Supreme Court, 1974 DuKE L.J. 59.

2. See Walter Murphy, Elements of Judiclal Strategy (1964) (describing a wide range of behaviors available to a Supreme Court Justice seeking to maximize his influence on public policy). 
institutional environment, to achieve certain goals. Most presume or purport to demonstrate that judges are guided by personal policy preferences; 3 some lawyer-economists and others posit different goals motivating judicial behavior. ${ }^{4}$ Whatever the presumed objective, however, some theorists have recognized that judges "are strategic actors who realize that their ability to achieve their goals depends on a consideration of the preferences of others, of the choices they expect others to make, and of the institutional context in which they act."5 In certain contexts a rational judge will deviate from her personal sincere views about the law in order to secure the most desirable collective decision possible, given the views held by the other relevant participants (judges or other governmental actors) who share input into that final collective decision. ${ }^{6}$

This political science scholarship is either empirical or predictive, identifying when strategic behavior does or is likely to occur. It tells us nothing about how judges ought to operate. This normative question is my focus here: Under what circumstances, and for what ends, may a judge appropriately engage in strategic behavior as a member of a multimember court?

Not infrequently, there will be opportunities for an individual judge to make her court's disposition of a case more compatible with her convictions overall by misstating her convictions as to particulars. The details may vary, but the abstract structure of these situations is simple. A judge will discover that by supporting an outcome or rationale with which she disagrees, she can prevent her court's adoption of some other outcome or rationale that she thinks worse either for justice in the case before her or for the state of the law, in general. ${ }^{7}$

3. According to the basic "attitudinal model," the United States Supreme "Court's decisions are based on the facts of a case in light of the ideological attitudes and values of the participating justices; in other words, on the basis of the individual justice's personal policy preferences." Harold J. Spaeth, The Attitudinal Model, in CoNTEMPLATING CourTs 296, 296 (Lee Epstein ed., 1995); see also Frank B. Cross, Political Science and the New Legal Realism: A Case of Unfortunate Interdisciplinary Ignorance, 92 Nw. U. L. REv. 251, $265-311$ (1997) (sketching and examining the attitudinal model).

4. These goals include such things as influence, immediate and historical reputation, and leisure. See, e.g., Richard A. POSNER, OverComm LAW 117-23 (1995) (discussing the "judicial utility function"); Richard A. Epstein, The Independence of Judges: The Uses and Limitations of Public Choice Theory, 1990 B.Y.U. L. REv. 827, 832-44.

5. Lee Epstein \& Jack Knight, The Choices Justices Make at xiii (1998).

6. Recent scholarship has focused on three aspects of a judge's institutional environment. Every judge is situated in relation to other judges in a temporal sense, because she is part of an ongoing enterprise in which both predecessor and successor judges contribute to the corpus of the law. Second, judges of lower courts are situated in relation to higher courts with the power of reversal. Third, each judge and her court are situated in relation to nonjudicial actors, including other governmental entities and the general public.

7. Kornhauser \& Sager, supra note 1, at 55. 
When such opportunities arise, must a judge be exclusively inputfocused, always voting for rules that reflect her best personal judgment as to how a legal issue ought to be addressed without considering how her input will affect the Court's collective output? Or may the judge be output-focused, voting to secure what she deems the best possible collective resolution of the case, even if to do so she must strategically suppress or misrepresent her sincere personal views?

Prevailing consensus appears to endorse some middle position. Certain forms of strategic behavior, such as insincere voting to forge a majority or unanimous coalition, are routinely practiced and viewed as permissible, perhaps even obligatory to some unspecified degree. ${ }^{8}$ Other forms, such as misrepresenting one's position in a case in order to better advance her preferred outcome in that very case, are either ignored or viewed with vague suspicion. ${ }^{9}$ Still other forms of strategic behavior, such as stark vote trading across unrelated cases, are roundly condemned. ${ }^{10}$

This article explores the intuitive normative differentiation between various forms and contexts of strategic voting. Judicial vote trading is repudiated: but why? Because it has pernicious effects? Because it employs impermissible means of decisionmaking?

8. See, e.g., Kornhauser \& Sager, supra note 1, at 52 (" $[\Pi]$ n deference to their colleagues, appellate judges are expected to compromise or deflect their views to some extent."). The norms governing this practice are rarely explored. See Richard H. Fallon, Jr., The Supreme Court, 1996 Term - Foreword: Implementing the Constitution, 111 HARv. L. Rev. 54, 59-60 (1997) ("In the literature on constitutional theory, ... [t]he practical and institutional pressures that require compromise to achieve workable doctrine receive scant attention.").

9. Some scholars have offered somewhat tentative and conclusory positions. See, e.g., Frank B. Cross, The Justices of Strategy, 48 Duke L.J. 511, 511-12 (1998) ("Judicial strategy is not much considered by legal scholars. ... [J] udges are typically considered to be above such devices."); Kornhauser \& Sager, supra note 1, at $8 \mathrm{n} .12,53$ (observing that the "simple line between strategic and sincere behavior seems inapt to multi-judge courts," and suggesting that "[p]erhaps a judge need only strive for the best that she thinks achievable on the given court" - but only within limits, for "she is not entitled to misrepresent her views or redirect her voting outcome in order to better advance her own candidates for rationale and outcome").

10. See, e.g., POSNER, supra note 4, at 126 ("vote trading by judges is condemned"); STEARNS, supra note 1 , at 152 (Justices are "expected not to trade votes or base their decisions on strategic considerations, as opposed to merits determinations"); id. at 196 (almost all forms of strategic voting represent "an indefensible method of determining" legal doctrines and outcomes); Linda R. Cohen \& Matthew L. Spitzer, Solving the Chevron Puzzle, Law \& CONTEMP. ProBs., Spring 1994, at 65, 84 ("[O]pen vote trading may violate norms of appropriate behavior on the Court."); Einer R. Elhauge, Does Interest Group Theory Justify More Intrusive Judicial Review?, 101 YALE L.J. 31, 106 (1991) ("[U]nder prevailing ethical norms judges cannot engage in the sort of logrolling that legislators commonly employ."). But see Lynn A. Stout, Strict Scrutiny and Social Choice: An Economic Inquiry into Fundamental Rights and Suspect Classifications, 80 GEO. L.J. 1787, 1826 n.164 (1992) (suggesting that judicial logrolling might improve "the stability of appellate voting and its accuracy in measuring group preferences"). 
Because it strives for impermissible goals? And once we identify the salient conceptualization(s) of adjudication that make this practice improper, what implications do those conceptualizations have for other forms of strategic voting, or even more conventional adjudicatory practices? At bottom, what are and should be the fundamental "rules of the game"11 governing collegial adjudication?

I approach this inquiry by identifying and exploring various conceptions of the adjudicatory process that can plausibly justify a norm prohibiting vote trading. My goal is neither to challenge the conventional wisdom that vote trading is improper, nor to defend it (although I agree with it) from a singular perspective; I shall let the reader draw her own conclusions on this score. My goal is to develop and explore analytical foundations for our currently vague intuitions regarding vote trading; more generally to edify our views concerning less controversial strategic adjudicatory practices; and most generally to provoke deeper thought about the nature and goals of collegial rather than solo-judge decisionmaking. Indeed, the ensuing discussion will expose just how much our understanding of multimember adjudication remains underdeveloped and the governing principles remain ambiguous. ${ }^{12}$ It will also highlight the implications of embracing various adjudicatory conceptions. Some arguments against vote trading also challenge other conventionally condoned or ignored judicial practices, and thus deeper consideration of vote trading may force us to rethink our current intuitions underlying other aspects of judicial decisionmaking. To the extent that judicial behavior is shaped by internalized professional rolecommitments, clarification of the proper norms governing multimember adjudication might actually influence the process by which judges transform their atomistic judgments into collective determinations. ${ }^{13}$

11. See PosNer, supra note 4, at 126-34 (characterizing judging as a game played by rules, with these rules acting as normative constraints on the types of materials and modes of reasoning judges may employ in rendering decisions).

12. I find it extremely significant that, in my many conversations with colleagues, their intuitions supporting an antitrading norm have reflected wildly divergent premises. With respect to each objection I identify and explore, some number of scholars thinks it captures the central conceptual difficulty with vote trading, while others think it quite wrongheaded or trivial.

13. See, e.g., Posner, supra note 4, at 132-34 (explaining why judges desire to "play within the rules" and thus will internalize and operate within perceived normative constraints on their discretion); Ronald A. Cass, Judging: Norms and Incentives of Retrospective Decision-Making, 75 B.U. L. REv. 941, 995 (1995) ("Professional norms narrow the ambit of judicial discretion."); Cross, supra note 9, at 539-40 (discussing judicial "role orientation" and its influence on decisionmaking processes). Adjudicatory norms might also be enforced through informal sanctions imposed both by fellow judges, see Mitu Gulati \& C.M.A. McCauliff, On Not Making Law, LAw \& ConTEMP. ProbS., Summer 1998, at 157, 166-70 
Before proceeding, some initial definitions and caveats are appropriate. First, the adjective "strategic" might seem ambiguous because different scholars use it for different purposes, and misleading because it sounds pejorative even though it is not intended as such. Throughout this article I shall use the term "sincere voting" to refer to the vote that represents an individual judge's top-ranked or ideal judgment as to what constitutes the best response to resolve a discrete legal controversy, without considering the impact of his vote on the substantive collective result in his court or in other institutions. In other words, a judge votes sincerely if he supports the position that he honestly thinks should win and that he would endorse were he alone on the court. I shall use the term "strategic voting" to refer to a judge's decision to vote for a position that does not truly reflect his "sincere" judgment in order to secure the best feasible outcome given the influence of his colleagues in the decisionmaking process. To keep this specific focus on collegial interplay in mind, one might mentally substitute the phrase "peerstrategic" for "strategic" as I employ it here.

Second, to make this inquiry more manageable, I confine my focus to strategic behavior by Justices on the Supreme Court of the United States. ${ }^{14}$ I also focus solely on the Court's merits determinations, even though the Justices confront opportunities for strategic behavior with respect to other important decisions as well.15

My inquiry proceeds as follows. Part I sketches the decisionmaking process of a Justice deciding cases by herself, and then uses this model of "solo adjudication" as a backdrop against which to introduce an input-focused and output-focused model of multimember adjudication. Part II details the opportunities and incentives for strategic voting on multimember courts, both with respect to the form of judicial opinions and their substantive content. Section III.A considers the extent to which norms governing solo adju-

(explaining why internal social-sanctioning mechanisms are likely to be effective on multimember courts), and by the public more generally (through esteem-reducing criticism), see id. at 206 ("Norms are inherently flexible, and information can alter them. This is especially true in the case of small, closely knit groups - such as federal appellate judges - who care greatly about their reputation and the esteem in which others hold them.").

14. Judges on every multimember court will confront a myriad of opportunities and incentives for engaging in strategic voting, but the propriety of their doing so may turn on nuances concerning their particular court's location and role within a differentiated and hierarchical judicial regime. For example, many view the Supreme Court as playing a smaller (or nonexistent) role in the just resolution of individual cases, and a greater role in futureoriented lawmaking, than do inferior courts. This distinction might affect the analysis in various ways.

15. See, e.g., EPSTEIN \& KNIGHT, supra note 5, at 58-65 (discussing strategic bargaining opportunities arising in the consideration of petitions for writ of certiorari). 
dication constrain Justices on collegial courts from engaging in vote trading and other types of strategic voting, and sections III.B through III.D consider whether this behavior is inconsistent with various conceptions of the teleology of multimembership in appellate adjudication.

When deeply probed, the intuitive line between acceptable and unacceptable strategic behavior grows more fuzzy, and its analytical grounding more elusive and complex. Perhaps in the end the propriety of strategic voting rests on one's choice of "first principles" of adjudication in general, and multimember adjudication in particular - principles that are not easily defended in analytical terms. Let me emphasize from the outset that I promise no definitive answers to some of the most important questions I ask about the aims of the multimember adjudicative enterprise. Exploration and illumination, more than conclusive resolution, are this article's objectives.

\section{Sincere Decisionmaking in Solo and Collegial Adjudication}

At the outset, let me identify this project's central premise concerning judicial motivation: subject to resource constraints, judges endeavor to discern and render their best judgment as to the proper resolution of cases according to their best conception of the law. $\mathrm{By}$ this assumption I intend to distinguish my analytical approach from that employed by much recent literature concerning judicial behavior, which posits that judges employ instrumental rationality to advance one or more personal agendas (such as a desire to imbue the substantive content of the law with their personal policy preferences, to enhance their professional reputation and personal prestige, and to enhance leisure). ${ }^{16}$ Whatever the extent to which such objectives actually influence judicial behavior, I embrace the conventional view that a normative account of adjudication should view judges as rendering judgments rather than expressing personal preferences about the law. ${ }^{17}$ For my purposes here I need not privilege any one of the various jurisprudential theories that have been developed to explain how Justices properly determine law's meaning

16. See supra note 4 .

17. While no doubt judges frequently issue opinions consistent with their own policy preferences, under most if not all plausible jurisprudential theories judges are not empowered to issue opinions simply because of consistency with these personal preferences. Judges are supposed to vote based on their judgment about the law even if that judgment fiatly conflicts with their policy preferences. This does not exclude the possibility, of course, that sometimes legal determinations properly consider issues of policy. 
and best implement that meaning through doctrine. Nor need I assume that each legal question has a uniquely and objectively "correct" answer. ${ }^{18}$ Rather, I simply assume here that each judge employs one of the available judgment-based "respectable jurisprudential paradigms" en route to answering legal questions to the best of her ability.

\section{A. Solo Judgment Formation}

Before considering the propriety of strategic behavior on multimember courts, we must first take a brief detour and consider the ways in which even judges sitting alone may take into account either decisions by other judges in other cases, or the views of nonjudicial actors about the same case. This initial focus on solo adjudication is sensible both because the norms governing such decisionmaking can inform the norms governing collegial decisionmaking, ${ }^{19}$ and because even judges on multimember courts generally determine their own views (at least tentatively) before considering the relevance of the views of their peers.

\section{Relational Judgment Criteria and Interconnecting Cases}

Assume that Justice Solo is the lone Justice on the Supreme Court. Each case before her Court contains one or more basic legal issues on whose resolution the proper case disposition depends. ${ }^{20}$ For each issue, Justice Solo evaluates various legal rules that could resolve the issue and then embraces the rule that in her judgment is the best of the alternatives. ${ }^{21}$

18. See, e.g., Lewis A. Kornhauser \& Lawrence G. Sager, Unpacking the Court, 96 YALE L.J. 82, 85-86 (1986).

At the core of the distinction between expressing a preference and rendering a judgment lies the proposition that some questions have "right" or "correct" answers. In this context, a "right" or "correct" answer need not be objectively true or depend upon some ultimate view of the real world; it may depend only upon intersubjective agreement over criteria for resolving disputes.

Id.; see also Frederick Schauer, The Jurisprudence of Reasons, 85 MrcH. L. REv. 847, 855 n.26 (1987) (" $[T]$ he idea of a right answer can survive the nonexistence of any way of noncontroversially proving that one answer is better than all others.").

19. See infra section III.A.

20. I put aside factfinding because neither the Supreme Court nor most other multimember courts have significant factfinding responsibility. One exception is three-judge federal district courts. See, e.g., Michael E. Solimine, The Three-Judge District Court in Voting Rights Litigation, 30 U. MrCH. J.L. ReFORM 79, 93 (1996).

21. Of course, "[i]n some hard cases ... a judge's view about the outcome of the case may be considerably more clear and more deeply held than her understanding of how an evolving doctrine should be shaped to support not just that outcome, but the correct outcome in future cases as well." Kornhauser \& Sager, supra note 1, at 56. This strong intuition about outcome might influence her ranking of potential justificatory legal rules. But her choice of doctrinal rule remains constrained, in the sense that she will not embrace a justification for 
Justice Solo's respectable jurisprudential paradigm yields a set of interpretation and implementation criteria with which she can evaluate and rank the possible legal rules. ${ }^{22}$ For example, her jurisprudential paradigm generates interpretive criteria by which to determine the Constitution's meaning, perhaps including the plain meaning of the text, Framers' intent, constitutional structure, historical developments, social or technological circumstances, prevailing societal consensus, and a balancing of societal interests. ${ }^{23}$ Justice Solo must also "implement" the Constitution's abstract meaning through specific types of doctrine, such as effects tests, purpose tests, or multifactor balancing tests. ${ }^{24}$ Her jurisprudential paradigm guides her choice among these doctrinal types 25 and counsels the breadth or depth of the doctrines articulated. ${ }^{26}$ In a given case (the "Instant Case"), the Justice draws upon these "intrinsic judgment criteria" to rank the alternative legal rules that address the legal issues at stake.

her intuitively favored outcome that "won't write." If necessary, she will generally abandon her preferred disposition in favor of an alternative dictated by a rule that "will write." See Cross, supra note 3, at 270 (discussing concept and providing examples).

22. Legal issues and rules are difficult to define precisely, although in practice their meaning is fairly clear. A legal issue "refers to some distinct or separable aspects of the case that can be decided in isolation from the case itself, that in part resolve the case, and that recur in 'similar' cases." Lewis A. Kornhauser, Modeling Collegial Courts II: Legal Doctrine, 8 J.L. Econ. \& ORG. 441, 446 (1992) [hereinafter Kornhauser, Modeling Collegial Courts II]. By legal rule, I simply mean a "doctrinal rule" as commonly understood by legal practitioners, a rule that governs the outcome of a specified issue in many related cases. Thus an articulation in a legal precedent qualifies as a legal or doctrinal rule if it establishes a precedent for deciding future cases. While some scholars have attributed precedential significance to various aspects of a judicial decision, see, e.g., Lewis A. Kornhauser, Modeling Collegial Courts I: Path-Dependence, 12 INTL. REv. L. \& EcoN. 169, 173-80 (1992) (arguing courts do and should embrace result-bound over rule-bound adjudication), the Supreme Court operates on the assumption that its articulated rules, rather than merely its holdings, qualify as precedent, see, e.g., Seminole Tribe of Florida v. Florida, 517 U.S. 44, 67 (1996); Antonin Scalia, The Rule of Law as a Law of Rules, 56 U. CHr. L. REv. 1175, 1177 (1989). I do not intend to discuss strategic joinder of "dicta" that lacks precedential significance.

23. See, e.g., Philip Bobitt, Constitutional Fate 1-119 (1982); John Hart Ely, DeMOCRACY AND DisTrust (1980); Richard H. Fallon, Jr., A Constructivist Coherence Theory of Constitutional Interpretation, 100 HARv. L. REv. 1189, 1194-1209 (1987).

24. For a more complete list of potential doctrinal forms, see Fallon, supra note 8, at 6775; Charles Fried, Types, 14 Const. Comm. 55 (1997) (dividing doctrines into effects, intents, and acts tests).

25. Witness the ongoing debate concerning the relative advantages of bright-line rules versus multivariate standards. See, e.g., Fallon, supra note 8, at 79-81; Scalia, supra note 22; Kathleen M. Sullivan, The Supreme Court, 1991 Term - Foreword: The Justices of Rules and Standards, 106 HARv. L. Rev. 22, 56-69 (1992).

26. For example, principles of judicial restraint such as those canvassed in Ashwander constitute implementation criteria favoring selection of a narrower over a broader rule when both resolve the issue presented. See Ashwander v. TVA, 297 U.S. 288, 347 (1936) (Brandeis, J., concurring). See generally CAss R. Sunsten, ONe CASE AT A TIME (1999) (defending procedural and substantive "minimalism" in judicial decisionmaking). 
Sometimes, however, Justice Solo's jurisprudential paradigm will dictate that a proposed legal rule is either favored or disfavored because of its interactive effects with another discrete legal rule not directly at issue in the Instant Case. Drawing an analogy to the concept of nonseparable preferences in the economics literature, we might say that a Justice has nonseparable judgments across the two legal rules, because her judgment as to the relative merit of one rule turns on the existence of the other. ${ }^{27}$ Such "relational judgment criteria" necessarily lead a Justice to look beyond the Instant Case to other germane issues raised in an Other Case.

The most commonly invoked relational judgment criterion is a specific form of consistency - the maintenance of a stable rule over time. This principle, captured in the doctrine of stare decisis, secures structural values such as predictability, stability, efficiency, and judicial legitimacy. ${ }^{28}$ The mere fact that in a Prior Case the Court announced Rule $A+$ to address Issue $A$ is itself a powerful (though not necessarily a sufficient) reason for a Justice to affirm rather than reject or modify Rule $A+$ in the Instant Case, even if the Justice views Rule $A+$ as suboptimal as measured by her intrinsic judgment criteria. ${ }^{29}$ This principle can operate in a forward- as well as backward-looking manner. ${ }^{30}$

27. See, e.g., Jean-Pierre Benoit \& Lewis A. Kornhauser, Assembly-Based Preferences, Candidate-Based Procedures, and the Voting Rights Act, 68 S. CAL. L. Rev. 1503, 1512-17 (1995) (defining and illustrating separable and nonseparable preferences in the context of electing candidates to a political assembly).

In other words, the choice between rules $A+$ and $A-$ to address Issue $A$ in the Instant Case depends on the choice between rules B+ and B-to address Issue B in a separate case, and vice versa.

28. See, e.g., Frederick Schauer, Precedent, 39 Stan. L. Rev. 571, 595-602 (1987).

29. See, e.g., Lewis A. Kornhauser, Stare Decisis, in 3 The New Palgrave Dictionary OF ECONOMICS AND LAW 509, 511 (1998); Schauer, supra note 18, at 849.

30. If a consistency norm dictates that Justice Solo and her successor Justices must treat what she does today as presumptively binding, then she must decide not only what is best for now, but also take into account how the current decision will affect the determination of future cases that will be guided by today's precedent. Justice Solo might well decide a case today in a manner that appears suboptimal with respect to her intrinsic judgment criteria, but that will likely generate the best possible extended rule over the series of future cases. See Evan H. Caminker, Precedent and Prediction: The Forward-Looking Aspects of Inferior Court Decisionmaking, 73 Texas L. Rev. 1, 11-12 (1994); Schauer, supra note 28, at 589.

A similar forward-looking phenomenon characterizes all rule-based decisionmaking (as compared to case-by-case balancing tests). Justice Scalia, for example, might believe that the balance of applicable factors favors the plaintiff in a particular case. But Justice Scalia prefers bright-line rules to balancing tests. See Scalia, supra note 22, at 1175 . He would therefore devise a bright-line rule that is optimal in the sense that, over the projected series of cases covered by the rule, it will lead to the proper outcome in as many cases as possible even if the plaintiff now loses in the Instant Case. See Frederick Schauer, Playing By THE RULES 135 (1991) ("[A]ccepting a regime of rules necessitates tolerating some number of wrong results - results other than those that would have been reached by the direct and correct application of the substantive justifications undergirding the rule."). 
A respectable jurisprudential paradigm may identify other relational criteria besides rule-consistency. Two discrete legal doctrines might serve as complements to one another, just as red wine complements red meat and white wine complements fish. One example concerns right-remedy definition. A Justice who views constitutional law as involving a balancing of societal interests may decide that giving a right a relatively broad scope is appropriate if and only if the remedy is relatively weak, and vice versa. Perhaps she would try to balance the scope of Fourth Amendment rights and the exclusionary rule to prevent "too many" criminals from going free due to a constable's blunder. 31 Other examples of complementarity abound. ${ }^{32}$ Like the consistency norm, complementarity can exert a forward-looking as well as a backward-looking influence. ${ }^{33}$

31. On one hand, courts have narrowed the scope of the exclusionary rule by recognizing various exceptions. See, e.g., United States v. Leon, 468 U.S. 897 (1984) (limited "good faith" exception); United States v. Havens, 446 U.S. 620 (1980) (impeachment exception). On the other hand, where the remedy of exclusion clearly applies, some suggest that "[i]]udges do not like excluding bloody knives, so they distort doctrine, claiming the Fourth Amendment was not really violated." Akhil Reed Amar, Fourth Amendment First Principles, 107 Harv. L. Rev. 757, 799 (1994).

32. For instance, a judge may favor regulation in a particular context if and only if another area is left effectively unregulated. See, e.g., Lee C. Bollinger, Jr., Freedom of the Press and Public Access: Toward a Theory of Partial Regulation of the Mass Media, 75 Mick. L. REv. 1, 26-37, 36 (1976) (arguing that the Court should uphold regulations designed to ensure access to the media, such as the "fairness doctrine," only when imposed on either the broadcast or print media but not on both, in order to balance "two distinct constitutional values").

For various examples drawn from federalism doctrine, see Evan $\mathrm{H}$. Caminker, Context and Complementarity Within Federalism Doctrine, 22 HARv. J.L. \& PuB. POLY. 161 (1998). For an example concerning separation of powers doctrine, see Peter B. McCutchen, Mistakes, Precedent, and the Rise of the Administrative State: Toward a Constitutional Theory of the Second Best, 80 CoRnell L. Rev. 1, 23-40 (1994) (arguing that the Court should have upheld rather than invalidated the one-House legislative veto, to restore a proper overall balance of power previously skewed by earlier Courts' erroneous decisions affirming unduly broad delegations of power to the executive branch).

For an intriguing discussion of yet another possible relational criterion, one running counter to the consistency norm, see Richard H. Pildes \& Elizabeth S. Anderson, Slinging Arrows at Democracy: Social Choice Theory, Value Pluralism, and Democratic Politics, 90 Colum. L. REv. 2121, 2172-74 (1990) (arguing that certain democratic values might be served by having the answer to some intractable legal/moral issues cycle over time, such that the law reflects the principles espoused by various groups at least some of the time).

33. Suppose Justice Solo views rules $A+$ and $B+$ as complements, and views rules $A-$ and $B$ - as complements. A case presents issue $A$ before the complementary issue $B$ is resolved. Justice Solo's intrinsic criteria identify rule $A+$ as a better answer than rule A- for the Instant Case. But suppose she can confidently predict that, when issue B does arise in a Future Case, her successor Justice will select B- over B+ (either because the successor does not view A+ and $\mathrm{B}+$ as complements, or because he views this relational criterion as less weighty than his intrinsic criteria that strongly prefer B-). Justice Solo now has a relational reason to prefer rule A- over rule $A+$ in the Instant Case, even though that is in tension with her intrinsic criteria which prefer A+. Depending on the relative weight of her intrinsic and relational criteria, she might well select rule A- today. Concededly, it may be difficult for Justice Solo to predict how a successor Justice will rule on a complementary issue. 
In determining the optimal legal rule to address a specific issue, Justice Solo consults both the intrinsic and relational judgment criteria that her respectable jurisprudential paradigm yields. In most instances, these judgment criteria enable her to rank a range of alternative rules, from "best" to "next-best" and so on. ${ }^{34}$ For ease of exposition, I will use R1 to denote the Justice's sincere judgment about the optimal legal rule, R2 to denote the Justice's secondranked choice, down through $\mathrm{Rn}$. I will sometimes characterize a Justice as "preferring" R1 to R2 to Rn, or voting her "preference" for R1, or "favoring" outcome R1, though I still mean to refer to a ranking determined by sincere judgment-based decisionmaking and not personal utility.

\section{Sophisticated Consideration of Nonjudicial Actors' Views}

Sometimes, an intrinsic judgment criterion might lead a Justice to consider the views of legislators or the general public in forming her sincere views on a legal issue. ${ }^{35}$ But once the Justice identifies her own sincere position (whether or not such deference plays a role in judgment-formation), she might still sometimes deviate from her sincere view of the Instant Case in order to accommodate the different view held by a nonjudicial actor. First, the Justice might suppress her sincere view if she predicts a negative reaction by a legislative body. For example, her sincere interpretation of a statute might prompt an overriding statutory amendment; her sincere interpretation of a constitutional provision might prompt either an overriding constitutional amendment or a stripping of judicial jurisdiction over future cases. She might therefore decide to embrace a

34. In certain contexts, the number of plausible alternatives capable of being ranked in intelligible fashion may be quite limited. Consider, for example, the interpretation of a statutory limitations period for filing a pleading. There might be only two plausible interpretations, one counting all calendar days and the other counting only business days, leading to two plausible dates on which the limitations period runs. While these two answers could be ranked intelligibly as better and worse, all other dates would seem to be equally wrong.

In other contexts one can imagine a dual equilibrium situation in which complementarity dominates any intrinsic criteria, such that a justice is truly indifferent between two complementary sets of rules, say B+ \& C+ and B- \& C-. See Benoit \& Kornhauser, supra note 27, at 1515 (showing, in the particular case of voter behavior in legislative elections, that if an individual has nonseparable preferences over the available options within two distinct choicesets, she may be unable unambiguously to rank the options in isolation). Such a situation certainly calls into question any jurisprudential claim that there exists a unique "right answer" to every legal question.

35. For example, Justices frequently defer to Congress's judgments by according its statutes a presumption of constitutionality. See, e.g., City of Boerne v. Flores, 521 U.S. 507, 535 (1997). Richard Fallon has recently argued that, when Justices engage in judicial review in the face of reasonable popular disagreement over the moral principles animating constitutional doctrines, they should accommodate the reasonable views of the public to some degree. See Fallon, supra note 8, at 147-48. 
suboptimal ruling in the Instant Case rather than to trigger a reaction that will move the law in an even more suboptimal direction. ${ }^{36}$

Some scholars have also suggested that a Justice might deviate from her sincere views if she fears a negative reaction by either the litigants or the general public. In the short run, a Justice might be concerned that a negative litigant or popular reaction to a specific sincere ruling would incite or entrench resistance and effectively undermine the Court's judgment or broader legal principles. If so, a strategic but suboptimal decision in the Instant Case might be preferable to a sincere but ineffective or even counterproductive judicial decision. ${ }^{37}$ With respect to long-term strategy, many have advised Justices not to stay significantly out of step with the public's deep-seated sentiments for long periods of time, else the Court's moral legitimacy and leadership will be undermined. ${ }^{38}$

36. In other words, if embracing R1 will likely lead to a legisiative move to R3, but embracing $\mathbf{R} 2$ would produce a stable result without triggering a legislative response, then the Justice might choose R2 in the first instance. See generally LAWRENCE BAUM, THE PUZZLE OF Judiclal BeHAVIOR 119-23 (1997) (summarizing research findings of others); EPSTEIN \& KNIGHT, supra note 5, at 139-57; Cross, supra note 9, at 525-31. Some scholars have posited that sophisticated behavior designed to promote the Justices' own policy preferences can incidentally promote various norms consistent with judgment-based decisionmaking, such as rule-of-law values (by avoiding legislative-judicial confrontation and concomitant temporal instability) and democracy values (by interpreting the law closer in line with prevailing majoritarian sentiments). See William N. Eskridge, Jr. \& Philip P. Frickey, The Supreme Court, 1993 Term - Foreword: Law as Equilibrium, 108 HARv. L. REv. 27 (1994). Of course, sometimes the best long-term strategy is to eschew case-specific sophisticated reasoning. See Howard Gillman, The Court as an Idea, Not a Building (or a Game): Interpretive Institutionalism and the Analysis of Supreme Court Decision-Making, in SUPREME COURT Decision-Making, 65, 72 (Cornell W. Clayton \& Howard Gillman eds., 1999) ("[S]ome justices, when faced with intransigent competitors, may think that both their short-term and long-term interests are best served by standing firmly behind an unpopular but principled judgment rather than by retreating or evading a conflict ....").

37. See, e.g., Alexander M. Bickel, The Least Dangerous Branch 247-54 (2d ed. 1986) (defending on these grounds the Court's "all deliberate speed" formula requiring gradual rather than immediate racial desegregation in Southern public schools); Dennis J. Hutchinson, Unanimity and Desegregation: Decisionmaking in the Supreme Court, 19481958, 68 GEO. L.J. 1, $61-67$ (1979) (discussing the Court's strategic decision in 1955-56 to duck the merits of an equal protection challenge to Virginia's antimiscegenation statute).

38. See, e.g., BICKEL, supra note 37, at 239 ("[T] he Court should declare as law only such principles as will - in time, but in a rather immediate foreseeable future - gain general assent.").

Lower court judges might also engage in sophisticated voting based on the anticipated review and potential reversal of their rulings by higher courts. Various political scientists have modelled inferior-superior court interaction, positing that lower courts sometimes issue suboptimal decisions to avoid foreseeable overrulings. See, e.g., Jeffrey A. Segal et al., Decision Making on the U.S. Courts of Appeals, in Contemplating CourTs 227 (Lee Epstein ed., 1995) (modelling lower court decisionmaking). In some circumstances, such sophisticated behavior might promote the norms underlying the doctrine of stare decisis. See Caminker, supra note 30 , at $36-43$.

This inferior-superior court relationship actually affords lower court judges sitting alone an intriguing opportunity and incentive to engage in a form of temporal vote trading with themselves. Suppose Judge Tryalone sincerely supports rule A in the Instant Case, but believes that his reviewing appellate court would view rule $\mathrm{A}$ as not only wrong but radically 
Given these possible reactions by nonjudicial actors, a Justice might strategically view her decision in the Instant Case as simply the first in a sequence of steps to achieving the best feasible rule as measured by her intrinsic and relational judgment criteria. Many consider this practice of taking into consideration future reactions by nonjudicial actors, which I will call "sophisticated voting," to be normatively controversial. ${ }^{39}$

\section{B. Sincere Judgment Formation on a Multimember Court}

The placement of Justice Solo on a multimember court creates opportunities for collegial interaction that can influence her solitary views. The process of collective deliberation can improve autonomous decisionmaking. A collegial sharing of ideas brings multiple possibilities and perspectives to each Justice's attention, and increases the likelihood that she will explore all plausible positions..$^{40}$ Moreover, each Justice is encouraged to hone and improve her own positions in response to critical peer scrutiny and persuasion. ${ }^{41}$

Some scholars suggest that collegial deliberation enables a more collective decisionmaking process that tends toward consensual rather than autonomous judgment formation. One might regard

so. Judge Tryalone might vote sophisticatedly in the Instant Case and refrain from endorsing rule $A$, not because he would likely be reversed in this case (although this is true), but because he would risk branding himself an extremist or loose cannon in the eyes of his reviewing court, and thus increase the likelihood that his rulings in Future Cases will receive harsher appellate scrutiny. In other words, Judge Tryalone would choose to vote insincerely in the Instant Case (by bringing his views closer in line to his reviewing court's views) to improve his chances of getting sincere rules $B, C$, and D past appellate review in Future Cases. Optimality in rule $A$ is traded for a future stream of improved rules. I think such sophisticated voting by Judge Tryalone would be highly controversial; suffice for now to say that some, but not all, of the normative objections to bilateral vote trading explored in Part III would apply to this unilateral strategy.

39. Some scholars use "sophisticated" and "strategic" interchangeably, but I want to draw a clear distinction here between a Justice's consideration of nonjudicial actors' future decisions and a Justice's consideration of her peers' views regarding the instant decision which is all I mean by "strategic."

Both legislative- and public-regarding sophisticated behavior have frequently been criticized. See, e.g., MURPHY, supra note 2, at 186 (suggesting that judicial consideration of current or future political reactions "would seem to defeat the very purpose of judicial independence"); Gerald Gunther, The Subtle Vices of the "Passive Virtues" - A Comment on Principle and Expediency in Judicial Review, 64 Colum. L. REv. 1 (1964) (criticizing Alexander Bickel's "passive virtues," some of which involve sophisticated reasoning).

40. See, e.g., Harry T. Edwards, Collegiality and Decision Making on the D.C. Circuit, 84 VA. L. REV. 1335, 1360 (1998); Kornhauser \& Sager, supra note 18, at 101.

41. "Strategic" tactics designed to "persuade" a colleague to modify her views more in line with one's own position, such as using personal influence, cajoling, and imposing informal sanctions, see generally MURPHY, supra note 2, at 43-56, do not count as "strategic behavior" for my purposes. If by using such tactics one Justice convinces the second to believe sincerely in rule $X$, neither Justice engages in "strategic voting" because both pursue their (ultimate) sincere positions. 
multimember courts as proper arenas for "dialogue, in support of judicial practical reason." 42 The epistemological premise of practical reason views the process of sincere judgment formation as collective or collaborative in nature, rather than autonomous. Practical reasoning is an art, guided by a commitment to constructing viable solutions to problems. This entails both a commitment to compromise and to the civility of discourse, which is necessary to sustain such reasoning over time. A Justice engaged in practical reasoning might, after failing to persuade his colleagues of the correctness of his own initial views, defer to their views as part of his effort to identify the correct answer on the merits. In brief, his decision to "go along" with his colleagues may signify a humility about his own tentative judgment and an overarching commitment to the process of practical reasoning as an ongoing enterprise, in light of which individual decisions matter less than the health of the continuing enterprise as a whole. ${ }^{43}$ In other words, in his view the "rightness" of a decision is, at least in part, grounded in the process and fact of group agreement.

Whether one views the formation of sincere judgments as a relatively autonomous or collective enterprise, the opportunity for collegial deliberation may strongly influence each Justice's views. When the time for deliberation ends, he can identify and vote his own sincere position.

But his vote is not determinative, and sometimes the Court's collective outcome will diverge from his sincere position. ${ }^{44}$ Should he then view his job simply as optimizing his input into the process by voting sincerely, indifferent to the ways in which his vote will affect the Court's collective resolution of a legal issue? Or may he focus on optimizing the Court's collective output, registering whatever individual vote is necessary to do so? The rest of this arti-

42. Frank I. Michelman, The Supreme Court, 1985 Term - Foreword: Traces of SelfGovernment, 100 HARV. L. REv. 4, 77 (1987).

43. See Fallon, supra note 8, at 148 ("The Justices' role ... is not exclusively one of truthtelling about the meaning of the Constitution (as each, personally, thinks that it ideally would be understood), but is also one, sometimes predominantly, of participating in a necessarily cooperative project ....").

44. Even advocates of practical reason must concede that, notwithstanding the epistemological pressure to achieve consensus, this will not always occur. See Jack Knight \& James Johnson, Aggregation and Deliberation: On the Possibility of Democratic Legitimacy, 22 PoL. THEORY 277, 283 (1994) ("[A]s some advocates of deliberation readily concede, while it aims at consensus there is no guarantee it will produce consensus. At some point then, matters will have to be put to a vote."). 
cle models and then considers the propriety of such an output focus in various contexts. ${ }^{45}$

\section{Opportunities AND Incentives for Strategic Voting ON A MULTIMEMBER COURT}

The strategic pursuit of legitimate adjudicatory values falls into two categories: strategic voting to improve the institutional efficacy of the Court's collective product through its quantitative form ("form-driven" strategies); and strategic voting to improve the substantive content of the Court's collective product ("content-driven" strategies). ${ }^{46}$ Before delving into the details, however, let me intro-

45. I assume throughout this paper that individual Justices engage in a rigorous and honest effort to determine their own sincere preferences, both prior to and during any collegial deliberation. My focus is on occasions when a Justice self-consciously votes inconsistently with what she perceives to be her "ultimate" sincere view. For present purposes I want to view the practice of sincere decisionmaking in its best possible light.

In reality, things are not so simple. For any number of reasons a Justice, even prior to deliberation, may not determine rigorously a sincere belief for every discrete legal problem she must decide. For example, she may choose to think about certain areas of law less than others for lack of time or interest or perceived evaluative capability; she may defer to other authorities (such as treatises) more in some areas than others; or she may cling to a belief without systematic investigation in one domain in order to maintain perceived consistency with her beliefs in another domain she considers more important (reflecting a desire to avoid cognitive dissonance). In a sense, each of these phenomena leads a Justice to sacrifice rigorous development of a sincere belief on one issue in exchange for adherence to a rigorously developed sincere belief on a different issue. One might loosely characterize this behavior as an "internal vote trade," although technically she does not self-consciously "vote against" her sincere belief on the former issue; she just never really forms such a belief in the first instance.

The collegial environment may add new psychosocial complexities undermining a stark division between sincere preference formation and strategic voting. For example, a Justice may "allow herself" to be persuaded by a colleague, and indeed might self-consciously perceive herself as persuaded, where the persuasion is really animated by the desire to engage (implicitly) in strategic behavior. Alternatively, a Justice who perceives herself as interested in a strategic maneuver, but believes such behavior is improper, might refrain from reasoning carefully about her sincere views in the first instance; by "not thinking too hard" about the case, she can act consistently with her strategic impulse but still maintain her self-image of propriety.

The causes or prevalence of such internal decisionmaking dynamics are beyond the scope of this article. These phenomena do suggest, however, that the line between "sincere" and "strategic" behavior may be far less crisp that I suppose.

46. I do not explore claims that multimember tribunals afford judges unique avenues of strategic voting designed to promote various personal agendas unrelated to optimal adjudication. For example, judges on a multimember court can expand their leisure time by joining colleagues' opinions with which they do not entirely agree, suppressing their disagreement in order to save the time required to write a concurring or dissenting opinion. See PosNer, supra note 4, at 124 (noting this phenomenon in the context of intermediate appellate courts). Judges on a multimember court who like winning for psychological reasons might deviate from their sincere views to join the winning coalition, and judges who seek status by enhancing their perceived importance may strategically position themselves in the middle of a contentiously divided court to establish themselves as "swing voters" who ultimately determine important outcomes. See, e.g., Tracey E. George, Developing a Positive Theory of Decisionmaking on U.S. Courts of Appeals, 58 Oнто ST. L.J. 1635, 1661-63 (1998). 
duce an analytic approach that is relevant for assessing the attractiveness of strategic voting across a range of circumstances.

\section{A. Assessing the Magnitude of Perceived Error of the Court's Output}

On a multimember court, sincere voting by a Justice will often lead to a collective outcome that she believes is wrong. She might, through strategic voting, be able to improve the collective outcome from a position she considers wrong to one she considers less wrong. To decide whether it is worth seizing this opportunity, she must first consider how important it is for her to supplant the greater error with the lesser one.

To make this assessment, she must determine not only her sincere order of preference for various rules ( $R 1$ through $R n$ ); she must also establish the relative degree of error in adopting each suboptimal rule. This latter determination I shall call the "magnitude of perceived error" (MPE). The following factors, among others, may be relevant to this calculation:

Error Costs - What principles are at stake in the choice between two rules? What tangible benefits or burdens are being allocated? A Justice might care more about articulating the best rule when it will determine issues of personal liberty, say guilt/innocence or imprisonment/execution, than when the rule will determine issues of financial consequence, say availability of punitive damages, or amoral policy concerns, say a procedural pleading requirement. ${ }^{47}$ And even with respect to a given tangible outcome the costs of a mistake may be asymmetrical: a Justice might believe that an erroneous conviction (where R1 calls for acquittal) is significantly worse than an erroneous acquittal (where R1 calls for conviction); she may believe that an erroneous denial of governmental subsistence benefits to an impoverished person is worse than an erroneous grant of benefits. ${ }^{48}$

Error Size - What is the size of a rule's perceived error? If the legal issue involves personal liberty, how much will be wrongly

47. See David L. Shapiro, In Defense of Judicial Candor, 100 HARv. L. Rev. 731, 750 (1987) ("There is a vast difference, for example, between sending someone to the gas chamber because of his race or religion and holding that the statute of limitations has run before an injury was discovered.").

48. For an example of one such asymmetrical valuation of mistakes, see In re Winship, 397 U.S. 358, 372 (1970) (Harlan, J., concurring) (noting that "a fundamental value determination of our society [is] that it is far worse to convict an innocent man than to let a guilty man go free"). 
granted or denied? If the legal issue involves money, how much will be wrongly allocated?

Error Rigidity - Can those governed by the rule circumvent its erroneous application? A Justice might care more about correctness with rules that impose immutable requirements on private conduct than with those that merely establish default rules around which private parties can maneuver.

Error Duration - How much precedential significance will the legal rule have? The more frequently the same or substantially equivalent issues will arise in the future, the greater the temporal "ripple effect" created by the Instant Case (given the relational judgment criterion of consistency), and thus the more important it is to be correct today. A Justice might care more about articulating the best rule to address a recurrent problem than about articulating the best rule governing an idiosyncratic statute that is about to sunset.

Error Certitude - How confident is the Justice in her rankings based on the aforementioned variables? Is she relatively certain that R1 is best, or is she sufficiently unsure that she might be inclined to defer to the different judgment of (some of) her colleagues? The more certain she is about $\mathrm{R} 1$, the more she will perceive any error as significant.

An MPE assessment of this sort, in one form or another, determines a Justice's incentive to engage in form-driven and contentdriven strategic voting in each of the circumstances described in this Part. Of course, the particular factors (and weights thereof) included in a Justice's MPE assessment are derived from her jurisprudential paradigm and, more specifically, the judgment criteria that guide her legal interpretations. For example, consider a Justice who embraces a strict "originalist" methodology in constitutional cases. For any discrete legal issue she can rank alternative rules according to how closely they conform to the Constitution's original meaning, but she will refuse to consider nonoriginalist reasons to prefer one rule over the next. In contrast, a strict "textualist" can rank alternative rules according to how closely they conform to the Constitution's textual meaning, but she will refuse to consider nontextualist reasons to prefer one rule over the next. The more capacious or multivariate a Justice's jurisprudential methodology, the more factors will become relevant to her comparison and ranking of alternative legal rules. 


\section{B. Strategic Voting to Improve the Form of Collective Decisions}

The form of a multimember court's product refers to the size of the Justices' agreement (e.g., unanimous, majority, plurality, or singular). Specific coalition sizes can promote various institutional values, and occasionally a Justice's desire to shape a particular coalition will incline her to endorse an outcome she views as substantively suboptimal. She might vote insincerely with respect to substance to forge a majority coalition supporting a disposition of the case, she might do so to forge a majority coalition supporting an opinion articulating a specific legal rule, and she might do so to forge a supermajority coalition such as an unanimous opinion. ${ }^{49}$

\section{Formation of Majority-Disposition Coalitions}

If the Instant Case presents three or more plausible dispositions, ${ }^{50}$ sincere voting might mean that no majority agrees on a single preferred disposition (for example, the Justices might split among affirm, reverse, and remand). Under the Court's prevailing aggregation rules, such a division prevents the Court from deciding the case. 51

The Court could avoid the potential impasse through various voting protocols, including: (a) adopt the disposition with the largest plurality support (if any); (b) hold a "run-off" vote between the top two vote-getting dispositions; or (c) compare dispositions two at

49. Technically, the Court needs a majority of a "quorum" of six to decide a case, so it takes at least four Justices (of seven sitting) to construct a majority-disposition or majorityopinion coalition. See 28 U.S.C. $\$ 1$ (1994); Robert L. STERN ET AL., SUPREME CoURT PRACTICE 2 (7th ed. 1993).

50. It is common but wrong to view cases as presenting a binary choice over dispositions between affirm and reverse; multiple dispositions are commonly available and occasionally plausible. The list includes the following: affirm, reverse, affirm in part and reverse in part (and Justices might disagree as to the particular parts), reverse and remand (with different types of instructions, which might even be viewed as a set of continuous rather than discrete options), vacate and remand (with same instruction options), dismiss the certiorari petition as improvidently granted, dismiss the petition/appeal for lack of Supreme Court jurisdiction, and vacate the proceedings below for lack of federal court jurisdiction. See 28 U.S.C. $\$ 2106$ (1994) (listing these options in less detail).

51. See Edward A. Hartnett, A Matter of Judgment, Not a Matter of Opinion, 74 N.Y.U. L. REv. 123, 140 (1999) ("A court must enter some judgment in order to dispose of the case. Without majority agreement on the judgment to be entered ... the case cannot be decided at all."). Interestingly, the proposition that the Court must affirmatively decide each case (even if only to decide not to decide the merits, for jurisdictional or like reasons) is assumed rather than defended. One could imagine resolving cases where no majority sincerely favors a single disposition by issuing a per curiam judgment "affirmed by a deadlocked Court," analogous to the conventional "affirmed by an equally divided Court." I will not pursue here whether or not this would be a wise procedural innovation; for present purposes, the point is a helpful reminder that judicial maneuvers are necessarily shaped and evaluated by the prevailing institutional environment and decisionmaking protocols. 
a time, and select the option that defeats all other alternatives in head-to-head competition if one emerges.

The Court has eschewed these structured routes. Rather, individual Justices "play chicken" until one faction gives in and shifts to its second-ranked rather than top-ranked disposition. In the final set of opinions issued, each of the factions (which might include from one to four Justices) articulates its sincere position. But one of the minority factions then explains that, in order to construct a majority-disposition coalition necessary to decide the case, the faction members will join another faction by voting for what they consider to be the second-best disposition..$^{52}$

A Justice's willingness to switch from his sincere to second-best disposition should depend on both institutional and substantive variables. First, how much value does he place on constructing a majority-disposition coalition such that the Court can issue a judgment in the Instant Case? Second, based on the magnitude of perceived error assessment how strong is his preference for his top-

52. A quintessential example is Klapprott v. United States, 335 U.S. 601 (1949). Four Justices (Reed, Vinson, Jackson, Frankfurter) voted to affirm the judgment below, and three Justices (Black, Douglas, Burton) voted to reverse and remand. The remaining two Justices (Rutledge, Murphy) announced that their preferred rule would lead them to reverse outright. However, these two Justices instead switched their actual vote to reverse and remand, thereby breaking the erstwhile deadlock by creating a majority coalition for this disposition. See 335 U.S. at 619 ("Since, however, that disposition [reversal] does not receive the concurrence of a majority, I join with those who, on other grounds, think that the judgment should be reversed and remanded for a new trial, in voting so to dispose of the cause.").

For a partial list of other cases illustrating the same phenomenon of disposition voteswitching, see John M. Rogers, "Issue Voting" by Multimember Appellate Courts: A Response to Some Radical Proposals, 49 V AND. L. Rev. 997, 998 n.4 \& 1032 n.118 (1996). See also Bragdon v. Abbott, 118 S. Ct. 2196 (1998) (two-Justice faction switched from outright affirmance to affirm and remand); Pennsylvania v. Muniz, 496 U.S. 582 (1990) (four-Justice faction switched from outright reversal to vacate and remand); Fort Wayne Books, Inc. v. Indiana, 489 U.S. 46 (1989) (single-Justice faction switched from jurisdictional dismissal to affirm and remand on one of two consolidated cases); United States v. Jorn, 400 U.S. 470 (1971) (twojustice faction switched from jurisdictional dismissal to affirm); Kesler v. Department of Public Safety, 369 U.S. 153 (1962) (single-Justice faction switched from jurisdictional dismissal to affirm); cf. Inman v. Baltimore \& Ohio R.R. Co., 361 U.S. 138 (1959) (single-Justice faction switched from dismissal of cert. petition to affirm, to avoid equally divided Court).

There appears to be no convention or pattern that the smallest of the multiple factions should switch its vote; the size of the switching group ranges from one to four Justices. There is, however, a pattern concerning the direction of vote switching. The cases fall into one of two categories: (1) a faction that sincerely believes the Court lacks jurisdiction switches to a merits-based disposition; or (2) a faction that sincerely believes the judgment ought to be affirmed or reversed switches to a disposition calling for some sort of remand. In no case did a faction switch to a jurisdictional dismissal or switch away from a remand to an outright affirmance or reversal. There is, however, no articulated rationale for these patterns in any of the cases. It appears that the choice whether to stand firm or switch (and to what) is left up to the strategic judgment of each faction. 
ranked disposition (D1) over his second (D2), and his secondranked over the third (D3) ? $^{53}$

It is difficult to determine just how frequently sincere voting generates such three-disposition impasses. ${ }^{54}$ The practice does suggest, however, general acceptance of an adjudicative norm that sincere views about case disposition may be sacrificed in order to facilitate the Court's case-deciding function.

\section{Formation of Majority-Opinion Coalitions}

Perhaps much more frequently, a majority of the Court will agree on a single disposition but disagree as to the optimal legal rule justifying that disposition. Sincere voting will leave the majority disposition supported by two or more divergent rules, each championed by a minority faction of one to four Justices. Such fractured support for the Court's disposition undermines various institutional values.

First, a fractured decision undermines the clarity of the legal rules that will govern future disputes, thereby increasing the unpredictability of the law's application to primary conduct and increas-

53. It is noteworthy that, given these incentives for strategic voting, the ultimate majoritydisposition will not necessarily identify a "Condorcet-winner" that would beat all alternatives in a series of pairwise comparisons, even if such a winner exists. For an explanation and illustration of the Condorcet voting paradox and cycling majorities, see, for example, HaNNU Nurmi, Comparing Voting Systems 12-14 (1987); William H. RIKER, Liberalism AgAINST Populism 67-81 (1982); STEARNs, supra note 1, at 81-88. Suppose three Justices compose each of three Court factions $\mathrm{J} 1, \mathrm{~J} 2$, and $\mathrm{J} 3$, and the factions have the following rank orderings across three alternative dispositions $A$ (affirm), $R$ (reverse), and D (dismiss)

$\begin{array}{lll}\text { J1 } & \text { J2 } & \text { J3 } \\ \text { A } & \text { R } & \text { D } \\ \text { R } & \text { D } & \text { R } \\ \text { D } & \text { A } & \text { A }\end{array}$

$R$ is a Condorcet-winner; it will beat $A(2-1)$ and $D(2-1)$ by majority vote. According to the Court's unstructured process, $R$ will emerge as the majority disposition if either factions $J 1$ or $\mathrm{J} 3$ switch first from their top-ranked to their second-ranked disposition $\mathrm{R}$. But $\mathrm{D}$ will emerge if faction $\mathrm{J} 2$ switches first to its second-ranked disposition $\mathrm{D}$. If $\mathrm{J} 2$ is more concerned about breaking the impasse than are $\mathrm{J} 1$ and $\mathrm{J} 3$, or if $\mathrm{J} 2$ is more concerned about avoiding its thirdranked disposition than are $\mathrm{J} 1$ and $\mathrm{J} 3$, then $\mathrm{J} 2$ will switch first, and $\mathrm{D}$ rather than the Condorcet-winner $\mathrm{R}$ will emerge as the collective choice. In theory, at this point $\mathrm{J} 1$ could approach $\mathrm{J} 2$ and point out that both would prefer $R$ to $D$, which they could achieve by agreeing that $\mathrm{J} 2$ would vote sincerely for $\mathrm{R}$ and $\mathrm{J} 1$ would vote strategically for $\mathrm{R}$. Such a second-round of bargaining would thus lead back to the Condorcet-winner. But unless each faction reveals its entire set of rankings - and it is unclear how often this might happen such a second-round of bargaining may never occur. Emergence of a Condorcet-winner thus depends on both the preference revelation and bargaining practices on the Court.

54. Researching published opinions reveals only a handful of cases in which the Supreme Court has faced and resolved such an impasse. See supra note 52. But the Court may confront such an impasse far more frequently. Potential deadlocks might be revealed and then resolved at earlier stages in the opinion-writing process, when one faction agrees not only to switch votes on the disposition, but to join a second-best rule justifying its second-best disposition as well. 
ing the costs of future decisionmaking by subsequent courts confronting the same legal issues. ${ }^{55}$ Second, it undermines the durability of legal rules, both by weakening the precedential value of the Instant Case, ${ }^{56}$ and perhaps also by diminishing public respect for judicial decisions generally. 57 Third, it undermines the expressive function of adjudication, by failing to articulate a singular, coherent justification for the judicial decision..$^{58}$ These institutional concerns are mollified to some degree when the divergent rules championed by two or more minority factions supporting the same disposition happen to be "nested, fitting within each other like Russian dolls."59 In such circumstances, the narrower nested rule establishes a precedent worthy of respect in future cases. ${ }^{60}$ But the mollification is only partial; "narrowest-grounds precedents" typically are not as clear, durable, or value-expressive as majorityopinion precedents. ${ }^{61}$ Thus fractured support for the Court's disposition will typically undermine one or more important institutional values, to a greater or lesser degree depending on the precise "nesting" or lack thereof among the divergent rules supporting the Court's collective disposition.

55. See, e.g., Cross, supra note 9 , at 550 ("[T] he best strategic reason for producing a majority opinion may be the room that a plurality opinion leaves for interpretive incompetence or clever disobedience by the lower courts."); Davis \& Reynolds, supra note 1, at 71-75 (plurality opinions often generate confusion about the law).

56. See Nichols v. United States, 511 U.S. 738, 746 (1994) (stating that lower court confusion in applying a splintered Supreme Court decision "is itself a reason for reexamining that decision").

57. See, e.g., LEARNED HAND, ThE BILL OF Rights 72 (1958) (arguing that a dissent "cancels the impact of monolithic solidarity on which the authority of a bench of judges so largely depends"); Archibald Cox, The Supreme Court, 1979 Term - Foreword: Freedom of Expression in the Burger Court, 94 HARv. L. Rev. 1, 72 (1980) ("Continuous fragmentation could well diminish not only the infiuence of the Court but the ideal of the rule of law.").

58. See Ken Kimura, Note, $A$ Legitimacy Model for the Interpretation of Plurality Decisions, 77 CORNELL L. REv. 1593, 1598 (1992) ("When two or more coalitions of concurring Justices reach the same outcome based on mutually exclusive legal rules, then that particular outcome has not been justified: it is merely the result of a chance happenstance, the meaningless intersection of conclusions."); $c f$. Pildes \& Anderson, supra note 32, at 2157 ("Objective outcomes are not all that matter; the expressive significance of how those outcomes are reached matters as well.").

59. Kornhauser \& Sager, supra note 1 , at 46.

60. See Marks v. United States, 430 U.S. 188, 193 (1977) ("When a fragmented court decides a case and no single rationale explaining the result enjoys the assent of five Justices, 'the holding of the court may be viewed as that position taken by those Members who concurred in the judgment on the narrowest grounds ...."') (citation omitted). For amplification of this "narrowest-grounds" rule, see Kornhauser \& Sager, supra note 1, at 45-48; Mark Alan Thurmon, Note, When the Court Divides: Reconsidering the Precedential Value of Supreme Court Plurality Decisions, 42 Duke L.J. 419, 427-46 (1992).

61. Lower courts frequently have difficulty discerning what rule, if any, constitutes the narrowest grounds for the judgment; and the Supreme Court adds to this difficulty by generally not according conventional stare decisis weight to such narrowest grounds there may be. See Thurmon, supra note 60, at 436-38. 
In response to these institutional concerns, one or more Justices often deviates from her substantively preferred rule in order to accommodate her colleagues sufficiently to form a majority-opinion coalition. Sometimes, the vote-shifting faction's opinion candidly reveals the decision to vote strategically. ${ }^{62}$ More frequently, the vote-shifting faction suppresses its sincere views in the published opinions, and the strategic behavior can be detected, if at all, only through careful research of what occurred behind the scenes. ${ }^{63}$

When deciding whether to vote sincerely and risk a fractured Court or strategically to construct a majority-opinion coalition, a Justice must decide if he is willing to accept some degree of substantive lawmaking error (measured by his MPE assessment comparing the substantive rules produced by sincere versus strategic voting) in exchange for the institutional benefits of a majority-opinion coalition. These benefits will be context-specific, both because clarity, durability, and legitimacy will be more important in some contexts than in others, and because they will be more significantly enhanced in contexts where the array of sincere rules would not even produce a narrowest-grounds precedent. Overall, strategic voting is most likely in the extreme case in which "it is more important that the applicable rule of law be settled than that it be settled right."64

62. For example, in Time, Inc. v. Hill, 385 U.S. 374 (1967), Justices Black and Douglas concurred in Justice Brennan's opinion of the Court to form a five-Justice coalition. Each wrote separately to express his sincere disagreement with the majority's legal rule, but explained his decision to concur "in order for the Court to be able at this time to agree on an opinion in this important case based on the prevailing constitutional doctrine." 385 U.S. at 398 (Black and Douglas, JJ., concurring).

63. See, e.g., EPSTEIN \& KNIGHT, supra note 5, at 96 (documenting that, in Nixon v. Fitzgerald, 457 U.S. 731 (1982), Justice Powell voted insincerely to forge a majority-opinion coalition, explaining that "[i]t is evident that a Court opinion is not assured if each of us remains with our first preference votes .... As I view the Nixon case as uniquely requiring a Court opinion, I am now prepared to defer to the wishes of you [Chief Justice Burger], Bill Rehnquist, and Sandra" in order to construct a single opinion of the Court); BERNARD Schwartz, Decision: How the Supreme Court Decides Cases 21 (1996) (documenting that, in Irwin v. Veterans Administration, 498 U.S. 1075 (1991), Chief Justice Rehnquist voted insincerely to forge a majority-opinion coalition, explaining to his colleagues that "I prefer the position taken in the most recent circulation of my proposed opinion for the Court, but want very much to avoid a fractionated Court on this point. ... If a majority prefers Nino's view, I will adopt it .... If there is some 'middle ground' that will attract a majority, I will even adopt that."). See generally EPSTEIN \& KNIGHr, supra note 5, at 97 ("[M]any other cases illustrate the extent to which opinion writers will put aside their most preferred position to generate a definitive ruling of the court - and one that represents the best they feel they can do under the circumstances.").

64. Burnet v. Coronado Oil \& Gas Co., 285 U.S. 393, 406 (1932) (Brandeis, J., dissenting).

As explained earlier, see supra text accompanying notes $42-43$, a Justice engaged in the collective enterprise of "practical reason" might deviate from her autonomous views and defer to those of her colleagues as part of her sincere judgment formation, rather than a desire to secure competing institutional values. In any particular case, however, a Justice will know for herself whether she perceives a tension between her sincere substantive view (how- 
It is frequently assumed that, in making these calculations, the majority will converge in a moderate or median position. This may well be quite likely when the Justices' ideal points can be lined up nicely in a single-peaked fashion along a single dimension, for instance from liberal to conservative. ${ }^{65}$ Convergence on a center position along the spectrum is not guaranteed, however, depending on the effects of small-group dynamics. Large factions may have greater ability to pull small factions (particularly a single Justice) to the former's sincere position than the other way around, and certain individual Justices may be more persuasive than others. ${ }^{66}$

But sometimes the options under discussion cannot easily be aligned along a single dimension. In addition to differing ideological premises, the rules may embody tests that reflect different implementation criteria (for example, rules versus standards), or make different expressive statements. One can imagine that a Justice's first- and second-ranked options could be on opposite sides of the substantive spectrum. ${ }^{67}$ If so, two factions on opposite ends of the spectrum might prefer to join together at either end rather than to join the middle faction. More to the point here, the outlier Justices may care little about securing the institutional values of a majorityopinion coalition, and the Justices in the middle of the spectrum may care a great deal. If so, a coalition will form only if the middle Justices move out to join one or the other wings. Thus convergence in form does not theoretically imply movement toward a schematically median or substantively moderate position. ${ }^{68}$

ever reached) and her desire to secure institutional values. If so, she faces the question of strategic trade-off discussed in the text.

65. Duncan Black's "median voter theorem" predicts that, if decisionmakers' preferences are single-peaked, then the outcome of a majoritarian voting protocol will gravitate toward the median voter's position, since her vote is necessary to secure a majority. See DuncaN Black, The Theory of Committees and Elections 19-24 (Iain McLean et al. eds., rev. 2d ed. 1998); Denns C. Mueller, Public Choice II 64-66 (1989) (describing theorem in both intuitive and quantitative terms).

66. See Gulati \& McCauliff, supra note 13, at 188 ("Individual judges can and do dominate the courts they sit on through personality, political savvy, the ability to build consensus, and, on occasion, sheer intellectual ability.").

67. Justice Scalia, for example, might be so wedded to bright-line rules that, after his sincere support for a bright-line conservative rule, he might in theory prefer a bright-line liberal rule to a moderate balancing test. For the converse proposition, see Fallon, supra note 8 , at 82-83 (observing that Justices who disagree about what determinate rule to apply may reach agreement on a balancing test).

68. See supra note 53. Admittedly, it is difficult to identify clear examples where two wing factions eschewed the middle and joined to forge a coalition. See STEARNs, supra note 1, at 153 (asserting that "strategic interaction between and among the Justices almost without exception appears to involve moves toward the median position on the Court"). The fact that this phenomenon appears uncommon suggests that Justices rarely perceive the institutional benefits of majority coalition formation as sufficiently strong to justify large deviations from the ideal substantive rule; Justices tend to be willing to make small substantive accom- 


\section{Formation of Supermajority Coalitions}

More infrequently, Justices coordinate their voting to produce a unanimous opinion. ${ }^{69}$ Unanimity establishes a very durable judicial precedent, and it may elicit greater respect from nonjudicial actors, both ensuring short-term compliance with the Instant Case disposition and ensuring long-term respect for the decision's underlying principles. ${ }^{70}$ More specifically, coordinated unanimity appears to be strategically deployed to counter perceptible threats to the Court's legal (and sometimes moral) authority. ${ }^{71}$ Each Justice who disagrees with the "consensus" position must decide whether the institutional values gained through unanimity outweigh the costs of deviating from her sincere legal position, and perhaps her sincere disposition as well. ${ }^{72}$

Even where unanimity is not attainable, Justices might also feel some impulse to add another voice to an existing majority coalition. Such "extra" joinders may add to a precedent's durability, ${ }^{73}$ which a

modations (by moving toward the middle) for institutional reasons, but are not willing to make large substantive sacrifices (by moving to the other end).

Professor Richard Fallon has recently advanced a different hypothesis: if there is an existing doctrinal structure, any forged consensus will likely converge around that doctrine because precedent "reflect[s] the result best situated to win majority acceptance as a reasonable accommodation of competing considerations." See Fallon, supra note 8, at 110.

69. For some recent noteworthy examples, see United States v. Nixon, 418 U.S. 683 (1974); Cooper v. Aaron, 358 U.S. 1 (1958) (per curiam); and Brown v. Board of Education, 347 U.S. 483 (1954). For a case study, see Dennis J. Hutchinson, Unanimity and Desegregation: Decisionmaking in the Supreme Court, 1948-1958, 68 GEO. L.J. 1 (1979). Coordinated voting to produce unanimous opinions was more common in earlier times, when dissents and especially separate concurrences were far less frequent than they are today. See Karl M. ZoBell, Division of Opinion in the Supreme Court: A History of Judicial Disintegration, 44 CORNELl L.Q. 186, 203-09 \& tbl.I (1959).

70. See, e.g., EPSTEIN \& KNGHT, supra note 5, at 106; Davis \& Reynolds, supra note 1, at 61-63.

71. See Cross, supra note 9, at 554-55. Chief Justice Marshall institutionalized the concept of a unanimous "opinion of the Court" to replace the traditional issuance of seriatim opinions precisely to enhance the respect and hence authority of the Court. See ZoBell, supra note 69 , at $192-95$.

72. Even if the Justices' preferences are single-peaked, the unanimous choice will not necessarily converge on the median voter's position, see supra note 65 and accompanying text, because that voter no longer holds a unique bargaining position, and thus Black's median voter theorem does not apply. See David A. Skeel, Jr., The Unanimity Norm in Delaware Corporate Law, 83 VA. L. REv. 127, 153-54 \& n.79 (1997) (suggesting as a "rough approximation" that unanimity will converge on the mean rather than the median position). Indeed, a strongly convicted Justice with outlier views might draw the others to her, if she is sufficiently entrenched and they are sufficiently driven to forge a unanimous coalition. In theory, unanimity might even alter the disposition of the case, in addition to the legal rule articulated, as compared to the outcome under majority rule.

73. Bare-majority coalitions may well command weaker stare decisis respect, and they are more susceptible to overruling due to fluctuating personnel. See, e.g., EPSTEIN \& KNIGHr, supra note 5, at 106; Saul Brenner et al., Increasing the Size of Minimum Winning Original Coalitions on the Warren Court, 23 PoLrry 309, 309 (1990). 
Justice might value even at the cost of a sincere vote. This would explain why members of an already-formed majority coalition frequently seem willing to accommodate a marginal Justice to some extent to entice her joinder, even though that entails further deviation from the majority's sincere position. In addition, a Justice might join a suboptimal option merely to conserve her scarce resources (time and energy) for cases she considers more difficult or more important to get right. ${ }^{74}$

For each of the types of coalitions described in this section, a Justice would weigh the institutional values to be gained against the costs of insincerity in the particular case, which may include institutional costs as well. ${ }^{75}$ Form-driven strategic voting appears to be a generally accepted practice on the Court. It is difficult for outsiders to identify each occurrence, however; Justices understandably do not candidly announce their decisions to form insincere coalitions when doing so would undermine their strategic purpose of projecting solidarity. ${ }^{76}$

Moreover, bare-majority coalitions might invite greater lower court circumvention efforts than large coalitions. See EPSTEIN \& KNIGHT, supra note 5, at 42 n.1.

74. Of course, such a Justice could just as easily save time by issuing a one-sentence opinion concurring in the judgment without explanation, rather than joining an opinion that does not reflect her sincere position. Not long ago this was common practice. See, e.g., Hansberry v. Lee, 311 U.S. 32, 46 (1940).

75. Some commentators have suggested that insincere coalition-formation is counterproductive to the extent it merely hides fissures within the coalition that will emerge later in related cases, thus decreasing the predictability of future legal developments. See, e.g., Earl M. Maltz, The Concept of the Doctrine of the Court in Constitutional Law, 16 GA. L. REv. 357, 401-03 (1982); Antonin Scalia, The Dissenting Opinion, 1994 J. SuP. CT. Hist. 33, 35, 38; Skeel, supra note 72 , at 148 \& n.61. A Justice unwilling to pledge future fidelity to the rule she would join in the Instant Case might view such a joinder as compromising such predictability, and hence as institutionally counterproductive in the long run.

Similarly, if Justices vote insincerely to form unanimous coalitions too frequently, these apparent agreements may come to be viewed as fake, and therefore the signaling value of such coordination will decline. For a strategically inclined Justice, then, this gambit contains its own self-dampening mechanism: the Justice would want to cap the frequency of coordinated unanimity in order to preserve its instrumental value.

76. Interestingly, while the text discusses situations in which a Justice is willing to vote insincerely to forge a desired coalition, there are situations in which a Justice might be willing to vote sincerely only if doing so would forge a desired coalition.

First, a Justice might want to advocate sincere rule $\mathrm{X}$ if and only if the rule were adopted by (at least) a five-member majority-opinion coalition. This stance would reflect an unwillingness to express $X$ in a "wasted" vote that might appear idiosyncratic and hence destabilizing. Such a Justice would communicate this stance by circulating a "Join-Four" memorandum, indicating her willingness to join four colleagues in the proposed opinion. For expression of such a sentiment in a published opinion, see Bellotti v. Baird, 443 U.S. 622, 65152 (1979) (Rehnquist, J., concurring) (expressing disapproval of existing precedent but also willingness to follow it until four colleagues join him in overruling it).

Second, a Justice might want to advocate sincere rule $\mathrm{X}$ if and only if the rule were adopted by an (at least) six-member majority-opinion coalition. This stance would reflect a desire to have rule $X$ prevail only in a supermajority rather than in a bare-majority victory, based on the concern that adoption of this particular rule by a bare majority would under- 


\section{Strategic Voting to Improve the Content of Legal Rules}

Due to conventional voting protocols, appellate courts offer individual judges fewer opportunities to engage in content-driven strategic voting than are available to members of many other collegial bodies. For example, legislatures often decide issues through a series of votes comparing two options at a time, sometimes called a motion-and-amendment process, such that savvy, sophisticated voting on early choices frequently can manipulate the ultimate path of alternative pairings and hence the substantive outcome. ${ }^{77}$ On the Supreme Court, each Justice typically registers a single vote to dispose of the entire case, rather than a vote resolving each issue raised by the case. ${ }^{78}$ Thus multiple-issue cases do not generally present a Justice with an opportunity to misrepresent her views on

mine institutional values. For example, a Justice might want to overrule a landmark precedent (say, Roe v. Wade), but fear that doing so by a 5-4 majority would make the decision seem too "politicized" or otherwise compromise its popular reception - better to wait for a supermajority so as to act with greater perceived authority. Such a Justice would communicate this stance by circulating a "Join-Five" memorandum, indicating her willingness to join five colleagues in the proposed opinion. She would thus thwart a majority coalition willing to adopt her sincere rule if only four colleagues were willing to join with her. See BoB WOODWARD \& SCOTT ARMSTRONG, THE BRETHREN 406 (1979) (observing that Justice Stewart had an unwritten policy not to join Nixon-appointed Justices as the fifth vote in favor of overruling a Warren Court precedent, even if he had dissented in the earlier case).

77. See Saul Levmore, Parliamentary Law, Majority Decisionmaking, and the Voting Paradox, 75 VA. L. Rev. 971, 1012-23 (1989).

78. In a handful of cases involving two discrete issues, a Justice who found herself in the minority on Issue One treated the majority's position on that issue as binding, and used it as a baseline from which to consider Issue Two. For example, in Commissioner v. Davis, 301 U.S. 619 (1937), Justice Cardozo authored an opinion for the Court joined by six Justices rejecting a challenge to the Social Security Act on the merits. Cardozo stated that he and three others believed the suit was nonjusticiable, but observed that "a majority of the court have reached a different conclusion," and "[u]nder the compulsion of that [majority] ruling, the merits are now here." 301 U.S. at 639-40; see Suzanna Sherry, Justice O'Connor's Dilemma: The Baseline Question, 39 WM. \& MARY L. REv. 865, 882-90 (1998) (describing similar phenomenon in five other cases, including two in which a Justice's deference to a majoritarian baseline on one issue changed both his and consequently the Court's collective vote on the disposition). In such instances, the baseline-adhering Justices (but not necessarily the others) acted as if the case should be decided through two separate, issue-by-issue votes. This practice is clearly exceptional, however. See, e.g., Hartnett, supra note 51, at 136-141; Kornhauser \& Sager, supra note 1, at 20. In other words, in multiple-issue cases Justices generally vote once, in a manner consistent with their internal resolution of all of the issues presented.

Of course, when an identical issue arises in a Future Case, the doctrine of stare decisis holds that a Justice should, at least presumptively, defer to the prior majority rather than to her own dissenting position. But the normative justifications for stare decisis, see supra text accompanying notes 28-30, do not similarly impel a Justice's deference to majoritarian resolutions of separate issues in the same case. Cf. Kornhauser, Modeling Collegial Courts II, supra note 22, at $452 \mathrm{n} .15$ ("[A] practice that requires judges to respect decisions reached on issues in previous cases does not necessarily imply that . . . each judge ought to respect the [majoritarian] resolution of each issue in the case as it is decided."). This may explain why insincere deference to a majoritarian position within a single case may strike some as vaguely troubling, whereas deference to a majoritarian position established by a Prior Case is presumptively appropriate. To put the point another way, the relational judgment criterion of 
one or more issues just to dictate the preferred resolution of the case as a whole. ${ }^{79}$ For this reason, perhaps the most frequently hypothesized scenario of strategic voting - in which a Justice insincerely votes to dismiss a case on jurisdictional grounds to avoid a decision on the merits with which she would strongly disagree 80 is much more complicated than advertised. ${ }^{81}$

This said, a Justice may still have the opportunity to guide the Court's collective output toward her sincere view through various forms of strategic voting behavior. I will focus primarily on two such scenarios, one unilateral and one bilateral.

\section{Unilateral Strategic Voting to Influence a Discrete Legal Rule}

Sometimes a Justice, by supporting a legal rule with which she disagrees, can unilaterally prevent a collective outcome that she considers even worse. Such a unilateral strategy might be attractive in either of two circumstances, both of which can helpfully be illus-

consistency becomes uniquely relevant in the two-case scenario, thus becoming part of the Justice's "sincere" assessment in Case Two.

79. See, e.g., David Post \& Steven C. Salop, Rowing Against the Tidewater: A Theory of Voting by Multijudge Panels, 80 GEo. L.J. 743, 750-58 (1992) (illustrating how, if cases were resolved through an issue-by-issue vote aggregation, a Justice with a strong preference for a particular outcome might promote that outcome by voting strategically on one of the component issues); see also SrEARNS, supra note 1, at 189-90 (arguing that the desire to avoid incentives and opportunities for such strategic behavior underlies the decision to employ outcome voting rather than issue-by-issue voting).

80. See, e.g., Kornhauser \& Sager, supra note 1, at 53.

81. Suppose three factions have the following sincere views. J1 believes the Court has jurisdiction, and should affirm. J2 believes the Court has jurisdiction, and should reverse. J3 believes the Court lacks jurisdiction, but if the Court had jurisdiction it should reverse. If the Court engaged in issue-by-issue voting and the factions voted sincerely, then the Court would assert jurisdiction (supported by $\mathrm{J} 1$ \& $\mathrm{J} 2$ ) and reverse (supported by $\mathrm{J} 2$ \& J3). J1 could avoid what she perceives as an erroneous merits decision by strategically voting against jurisdiction; then the collective outcome would be a jurisdictional dismissal (supported sincerely by $\mathrm{J3}$ and strategically by $\mathrm{J} 1$ ).

But the Court in fact votes by outcome rather than issue-by-issue. If each faction votes sincerely, the Court ends up deadlocked among the three possible outcomes: affirm (J1), reverse (J2), and dismiss (J3). See supra section II.B.1 (discussing the problem of initially deadlocked cases). $\mathrm{J} 1 \mathrm{might}$ decide to vote strategically for dismissal (to avoid the possibility that J3 will switch over to J1's third-ranked outcome of reversal); but she then forgoes the possibility that either $\mathrm{J} 2$ or $\mathrm{J} 3$ will switch over to her top-ranked outcome of affirmance. Her strategic response depends on her assessment of her colleagues' strategic responses. Thus the oft-heard scenario - voting insincerely against jurisdiction to avoid a bad merits decision is more complicated than it first sounds. Cf. H.W. Perry, JR., Deciding to Decide: Agenda Setting in the Unired States Supreme Court 198-207 (1991) (discussing the occasional strategic practice of "defensive denials" of cert. petitions, when a Justice fears that the Court will decide a case unfavorably on the merits).

It is interesting that, of the initially deadlocked three-disposition cases identified above in which one option was a jurisdictional dismissal, see supra note 52 , in each case the faction favoring dismissal switched to a merits disposition, not the other way around. 
trated by focusing on Justice Brennan's behavior in Craig $v$. Boren. ${ }^{82}$

Under an intentionally simplified version of the case, the relevant legal issue was whether discrimination on the basis of sex should be subject to strict scrutiny (SS), intermediate scrutiny (IS), or rational basis scrutiny (RBS). Suppose the Justices' first-rank judgments divided them into three equal-sized factions as follows: Justice Brennan's faction preferred SS; Justice Powell's faction preferred IS; and Justice Rehnquist's faction preferred RBS. Justice Brennan's first-rank judgment can be gleaned from the fact that he recently had advocated SS in Frontiero v. Richardson, ${ }^{83}$ though he had failed to convince a majority. ${ }^{84}$ But in Craig, Brennan circulated a draft opinion for the Court that advocated intermediate scrutiny, a view that ultimately won the day.

Brennan apparently concluded that it was preferable to vote strategically to establish a durable precedent now for IS, rather than to vote sincerely for SS. There are two different scenarios under which such a strategic maneuver makes sense. The first ("Craig I") involves an effort to influence the precedential significance of the decision, assuming that all other Justices remain steadfast; and the second ("Craig II") involves an effort to influence the collective outcome by encouraging another Justice to change her vote.

First, Brennan might have assumed that the Court would remain fractured across the three tests as described above, and that Powell and his faction would join the Brennan faction in invalidating the sex-based classification. If so, Powell's IS test would have established a precedent of sorts under the narrowest-grounds rule. ${ }^{85}$ But Brennan might plausibly have feared that an increasingly conservative Court would embrace RBS in a Future Case, brushing the weak

82. 429 U.S. 190 (1976). Others have described Craig as an archetypal example of unilateral strategic voting. See, e.g., EPSTEN \& KNIGHT, supra note 5, at 1-9; Cross, supra note 9, at 551-52 ("Craig is a convincing illustration of how Justice Brennan compromised his desire for a strict scrutiny standard for gender discrimination in order to command a majority."). But none have fully explained the strategic opportunities and incentives facing Justice Brennan. Of course, no observer can know for certain whether or precisely why Justice Brennan behaved strategically in Craig. The case does, however, usefully illustrate hypothetical incentives for such behavior.

83. 411 U.S. 677 (1973).

84. See Bernard Schwartz, The Ascent of Pragmatism 222-27 (1990).

85. See supra notes 59-61 and accompanying text. Note that Brennan has no strategic incentive to join Powell in advocating IS unless Powell would invalidate (rather than uphold) the statute under that standard; Brennan's vote can influence the precedent established only if he is in the majority-disposition coalition. 
Craig precedent for IS aside. ${ }^{86}$ Brennan could then try to pretermit this most disfavored possibility by strengthening the Craig precedent, through joining Powell's position to forge a majority-opinion coalition invalidating the statute under intermediate scrutiny. This Craig I scenario illustrates Brennan's ability to forestall a highly disfavored outcome (a majority-backed precedent for RBS in a Future Case) by influencing the precedential significance of the Instant Case. ${ }^{87}$

86. Recall that the Court has traditionally accorded little stare decisis weight to its own previous narrowest-grounds decisions. See Thurmon, supra note 60, at 437-38.

87. Sometimes a Justice might try to influence the precedential significance of a case even without forging an insincere majority-opinion coalition. Consider Edward Lazarus's account of Justice Brennan's behavior in Patterson v. McLean Credit Union, 491 U.S. 164 (1989). See Edward Lazarus, Closed Chambers 306-25 (1998). The relevant legal issue was whether racial workplace harassment constitutes a violation of 42 U.S.C $\$ 1981$ 's prohibition against racial discrimination in the "making" of a contract. At the Conference vote, Justice Brennan led a group of four who said yes, Justice White led a group of four who said no, and Justice Kennedy tentatively agreed with the Brennan faction. Brennan circulated a draft opinion holding that harassment-victim-and-plaintiff Brenda Patterson stated a $\$ 1981 \mathrm{claim}$, and Justice White circulated a draft dissent (which Chief Justice Rehnquist joined) holding that Patterson did not state a claim. Over time, Justice Kennedy was persuaded to abandon his tentative Conference position and conclude that $\S 1981$ afforded Patterson no cause of action on these facts. Justice Kennedy circulated a draft opinion to this effect, which was quickly joined by Justices O'Connor and Scalia. At that moment it appeared that the Court would rule against Brenda Patterson based on a fractured opinion, since the Kennedy faction of three embraced a somewhat different rule and rationale than the White faction of two. Under these circumstances, Brennan's sincere dissent for four Justices ruling for Patterson would have no precedential consequence.

In an apparent scheme to alter the case's precedential significance, Brennan circulated a new draft that maintained his sincere legal rule (that postcontractual harassment could violate $\S 1981$ ) but switched the disposition, holding against the victim on the ground that she failed properly to plead the facts relevant to this legal rule. If Brennan could keep his faction together, then the Court would be unanimous on the disposition in rejecting Patterson's claim. But Brennan's position would have more votes than any other in the 4-3-2 split, and thus he would still write the lead opinion. I put aside here the complicated question of whether any of the three positions would have any precedential status under the narrowestgrounds rule; suffice it to say that Brennan might reasonably have believed that - at least with respect to lower courts if not a future Supreme Court - a lead opinion for four Justices ruling against Patterson but embracing an expansive view of $\$ 1981$ would mute the decision's conservative cast.

But Brennan's gambit failed. Justice White responded by withdrawing his separate opinion and joining Kennedy's, and Rehnquist quickly followed suit. Kennedy now commanded a majority-opinion coalition, and thus his position would clearly establish precedent no matter what Brennan did. Predictably, once the strategic opportunity evaporated, Brennan immediately switched back to his original position vindicating the plaintiff's claim. While shortlived, Brennan's Patterson ploy thus illustrates the possibility that a Justice might strategically mold a decision's precedential significance even without forging a majority coalition, as in the Craig I scenario.

Justice Brennan's gambit in Patterson has been described differently, as an effort to sway Justice Kennedy's position on the merits. See JAMEs F. Simon, The Center Holds 19-81; id. at 64 (1995) (suggesting that Brennan was trying to "entice Kennedy to rejoin Brennan's [strategically reconfigured] majority," because it reached the result Kennedy wanted to reach even though it set the legal precedent Brennan wanted to set by interpreting the $\S 1981$ cause of action relatively broadly). I find this explanation for Brennan's strategic behavior implausible, both because I agree with Lazarus that Brennan knew full well by this time that Kennedy would reject a broad reading of $\S 1981$, see LAzARUs, supra, at 317 n.*, and also 
The Craig II scenario involves an effort by a strategic-minded Justice to induce a colleague to change her articulated position, thus changing the collective outcome in a favorable direction. Such an opportunity may arise whenever the colleague's preference is multidimensional, meaning there are two or more variables that drive her ranking of rules. In such circumstances a Justice sometimes can, by strategically repositioning himself, create or destroy multidimensional options and thus influence the colleague's selection from among the available options. ${ }^{88}$

For example, suppose Justice Powell and his faction are concerned with both the substance and form of the collective decision in Craig. Powell favors IS, but he also favors construction of a majority-opinion coalition to secure the concomitant institutional benefits. Suppose further that Powell's form-driven preference dominates, such that he prefers to forge a majority opinion even at the cost of abandoning IS. If Powell prefers RBS to SS, then he would be inclined to join the Rehnquist faction at RBS to secure the institutional values of a majority-opinion coalition. ${ }^{89}$ Brennan could rationally try to forestall this most disfavored possibility by embracing IS rather than SS. This strategic maneuver would induce Powell to stay with IS rather than shift to RBS, by enabling Powell to secure both his preferred substance (IS) and form (joining

because there is no reason to suspect that Kennedy cared about the Court's disposition (whether Patterson won or lost) as an independent aspect of the case.

88. No similar opportunity arises if one assumes that the Justices' ideal points line up nicely along a single dimension, say, liberal to conservative ideology, or zero to large monetary damages. If so, then the collective outcome will be determined by the position of the median Justice. See supra note 65 . This position may or may not articulate a narrowestgrounds precedent governing Future Cases, but either way it will dictate the disposition of the Instant Case. There is no reason to think that a strategic-minded Justice could, merely by altering his own articulated position along that spectrum, induce the median (or any other) Justice to deviate from her sincere position. Suppose Justice Wapner's top-ranked rule lies at the far left end of the single-dimensional spectrum. Whether he deviates from that sincere position by moving farther to the left away from the median, or farther to the right and toward (but not across) the median, his movement neither reconstitutes the median spot nor provides any incentive for the median Justice (or any other) to move from her sincere position. The median Justice still has the ability to control the disposition, and therefore she should continue to vote sincerely. Justice Wapner can in theory change the median point on the spectrum only by repositioning himself to the right of the initial median spot - but of course this would worsen rather than improve the resulting collective outcome from Wapner's perspective, and thus would be self-defeating.

89. Presumably Powell, like Rehnquist, would uphold the statute under RBS. This is not only because statutes almost always satisfy rationality review, but also because Powell's failure to support Rehnquist's disposition as well as his rule would thwart Powell's self-conscious effort to secure the institutional values of a majority-opinion coalition.

Some readers might be troubled by the notion that Justice Powell would willingly support a less-preferred substantive rule when doing so alters the disposition of the case (upholding rather than invalidating the statute, and hence ruling against rather than for the plaintiff). I explore this intuitive discomfort at infra section III.A.1.a. 
Brennan in a majority-opinion coalition). This Craig II scenario illustrates Brennan's ability to avert a highly disfavored outcome (a majority-backed precedent for RBS in the Instant Case) by influencing a colleague's vote in this case.

In both scenarios illustrated through Craig I and II, Justice Brennan could rationally conclude that the project of best implementing the law according to his intrinsic and relational judgment criteria dictated a strategic choice to eschew his sincere position SS and enshrine his second-ranked rule IS now, thereby averting the present or future possibility of his third-ranked RBS. This archetypal scenario of unilateral strategic behavior can be modelled as follows, applying the "magnitude of perceived error" concept developed earlier. ${ }^{90}$ According to Justice Brennan's intrinsic and relational judgment criteria, his ranking of the three rules proposed in Craig is as follows: $\mathrm{R} 1=\mathrm{SS}, \mathrm{R} 2=\mathrm{IS}$, and R3 = RBS. When deciding whether to vote strategically, Brennan should consider both the likelihood of the Court ultimately settling on each option and the MPE represented by the two suboptimal rules, R2 and R3. With respect to the former variable, the more confident Brennan is that unless he forges a majority opinion coalition for IS in the Instant Case a majority will embrace RBS in a near Future case (Craig I) or even the Instant Case (Craig II), the more willing he should be to vote strategically. With respect to the latter variable, the more he views $\mathrm{R} 2$ as a minor error and $\mathrm{R} 3$ as a major one, the more willing he should be to vote strategically and create a minor error in order to prevent a serious one. 91

The unilateral strategic ploy in which a Justice votes for R2 to forestall a collective outcome of R3 is likely a common occurrence, even though the strategy typically cannot be detected by outside observers or perhaps even colleagues. Justices quite frequently change their views over the course of a decision. ${ }^{92}$ Of course, this

\section{See supra section II.A.}

91. The above analysis assumes that, if a majority-opinion coalition forms around $R 2$ in the Instant Case, this will establish a durable precedent. A Justice favoring R1 might be even more willing to vote strategically for $R 2$ in the Instant Case if he still felt free, consistent with his own commitment to stare decisis principles, to fight for R1 in a Future Case if he suddenly thought (perhaps due to personnel changes) that $R 1$ had become a feasible alternative. On the other hand, the Justice might be less willing to vote strategically for $R 2$ in the Instant Case if he believed that victory would be short-lived because other members of the coalition would likely defect to R3 in a Future Case. The Justice's assessment of R2's durability given his own and others' stare decisis commitments, coupled with his prediction of the Court's future trends, thus could also play a role in his decision whether to vote sincerely or strategically in the Instant Case.

92. For an overview of the literature discussing this phenomenon, see Saul Brenner, Fluidity in Voting on the United States Supreme Court: A Bibliographic Overview of the Studies, 
sometimes reflects a change in sincere views. Sometimes this behavior is driven by the institutional benefits of a majority opinion coalition, but anecdotal evidence suggests that this is not the primary motivation. Most of the time, I think Justices care about forging a majority coalition only if it settles on a rule they support - at least support enough. If asked whether they would prefer a majority-opinion coalition to coalesce even if they would be left in dissent or concurrence, I'd bet most often they would say no. If my surmise is correct, then much of the documented position jockeying and concession granting on the Supreme Court reflects strategic behavior designed to improve the content of legal rules..$^{93}$

To make the normative discussion in Part III as clean as possible, I will focus on the archetypical Craig scenarios when exploring the propriety of unilateral maneuvers. It is worth noting, however, that other plausible content-driven unilateral strategic voting scenarios can be identified. For example, a Justice might try to move the law a great distance through small incremental steps, securing the most favorable victory feasible on the Court at each point in time. ${ }^{94}$ Second, a Justice might articulate a sincere view, and yet because it fails to win the day, also articulate an alternative lower-ranked rule in an effort to move the law as close as feasible to his sincere view. ${ }^{95}$ Third, occasionally a Justice will seemingly waffle back and forth over a series of cases as she sometimes embraces, and then some-

87 LAW LIBRARY J. 380 (1995). For various anecdotal stories concerning such fluidity, see LAZARUS, supra note 87; SCHWARTZ, supra note 84; SimON, supra note 87.

93. See Lawrence Baum, What Judges Want: Judges' Goals and Judicial Behavior, 47 PoL. REs. Q. 749, 759 (1994) ("The extent to which Supreme Court Justices engage in strategic behavior is uncertain. It does seem clear that such behavior is not rare, particularly in the form of strategy to influence collective decisions of the Court."). Of course, content-driven and form-driven motivations are not mutually exclusive. In a given case a Justice might be motivated to vote insincerely to form a coalition both to secure particular institutional values and to avoid a substantively worse outcome.

94. To illustrate, suppose a Justice wants to move the law a great distance from where he finds it, say R5 in his view, to his R1. Rather than voting for R1 in the first case raising the issue and creating a fractured set of opinions, this Justice would advocate and secure a majority coalition for $\mathrm{R} 4$ in that case, and then advocate and secure a majority for $\mathrm{R} 3$ in the next, and so on until he finally gets a Court for R1. This strategy is designed in each case to nudge his reluctant colleagues as far as they can be moved, so that the next case provides a closer jumping-off point from which to leap finally to R1.

95. For example, consider Justices Brennan and Marshall's longstanding adherence to their sincere view that the death penalty is, in all circumstances, cruel and unusual punishment. See Gregg v. Georgia, 428 U.S. 153, 229 (1976) (Brennan, J., dissenting); 428 U.S. at 231 (Marshall, J., dissenting). In numerous cases Justices Brennan and Marshall joined or even authored majority-opinion coalitions invalidating a death sentence on specific, narrow grounds, but also included a separate statement maintaining their opposition to the death penalty on their sincere and broader ground. See, e.g., Gardner v. Florida, 430 U.S. 349, 36465 (1977) (Brennan, J., concurring); Godfrey v. Georgia, 446 U.S. 420, 433-34 (1980) (Marshall, J., concurring). 
times abandons, a particular legal rule. It is possible that the Justice's sincere view has changed back and forth over time; but it seems more likely that one view is sincere, and the other is expressed only when and because it is strategic to do so. ${ }^{96}$ Fourth, a Justice might threaten to write a dissenting opinion unless the majority modifies its opinion so as to move the announced rule closer to the threatening Justice's top-ranked position. ${ }^{97}$ I suspect that these additional examples of unilateral strategic voting beyond the archetypal Craig scenario are quite common, though precise quantification is difficult. ${ }^{98}$

96. For example, consider Edward Lazarus's account of Justice O'Connor's reasoning in City of Richmond v. J.A. Croson Co., 488 U.S. 469 (1989), pertaining to the proper level of scrutiny applied to a state affirmative action program. According to Lazarus, O'Connor insincerely articulated an argument (that state programs should be more strictly scrutinized than federal programs) in order to distinguish Croson from Fullilove v. Klutznick, 448 U.S. 448 (1980), and then abandoned the argument again when she could secure a Court for her sincere position in Adarand Constructors, Inc. v. Pena, 515 U.S. 200 (1995) (applying the same strict scrutiny to federal as to state programs). See LAzARus, supra note 87, at 299-301.

For another example, consider Don Regan's account of Justice Powell's wavering dormant Commerce Clause reasoning in Edgar v. MITE Corp., 457 U.S. 624 (1982), and CTS Corp. v. Dynamics Corp. of America, 481 U.S. 69 (1987), concerning application of the balancing test established in Pike v. Bruce Church, Inc., 397 U.S. 137 (1970). Powell's vote was expressly insincere in one sense. See Edgar, 457 U.S. at 646 (stating his belief that the "case is moot," but deciding to reach the merits because of "the decision of a majority of the Court" to do so). Regan argues that Powell's merits position supporting the Pike balancing test was strategic as well. Without Powell's vote there was a majority-disposition coalition invalidating a state statute but no majority-opinion coalition, with a plurality embracing several different doctrinal arguments. Powell joined only the plurality's Pike balancing analysis - thereby forging a majority-opinion coalition for this argument alone - in order to establish a precedent that was as little restrictive of state authority as possible given the options. Subsequently in CTS, Powell distinguished Edgar and upheld a state statute without engaging in the Pike balancing that his own precedent-creating joinder in Edgar would appear to have dictated, and without explaining this omission. See Donald H. Regan, The Supreme Court and State Protectionism: Making Sense of the Dormant Commerce Clause, 84 Mrch. L. Rev. 1091, 1278-83 (1986); Donald H. Regan, Siamese Essays: (I) CTS Corp. v. Dynamics Corp. of American and Dormant Commerce Clause Doctrine; (II) Extraterritorial State Legislation, 85 Mirch. L. Rev. 1865, 1866-68 \& n.18 (1987).

97. The majority might be willing to move either to increase the coalition size for institutional reasons or for personal, non-judgment-based reasons (such as to avoid public criticism or ridicule). Either way, the would-be dissenter ends up joining the majority in a strategic vote for a suboptimal, but still better-than-before, legal rule.

The threat of a dissent probably has greater force on intermediate appellate courts, because unanimous opinions are less likely to be reviewed. See Frank B. Cross \& Emerson H. Tiller, Judicial Partisanship and Obedience to Legal Doctrine: Whistleblowing on the Federal Courts of Appeals, 107 YALE L.J. 2155 (1998) (arguing that a judge in the minority can encourage the majority members to modify their proposed views by threatening to dissent, thereby signaling to the Supreme Court that the case should be reviewed).

98. I would not count as strategic voting the common practice of a dissenting (or even concurring) Justice intentionally misdescribing the rule announced in a majority opinion in an effort to influence its interpretation in subsequent cases. The dissenter's maneuver is an attempt to move the meaning of the majority's rule closer to the dissent's sincere position, but does not require the dissenter to embrace a suboptimal rule himself. 


\section{Bilateral Vote Trading}

Justices will sometimes confront an opportunity to trade votes with one another; each of two Justices votes for the other's sincere view on one issue in exchange for the other's support of his sincere view on another. Such an agreement can be either explicit or tacit.

a. Explicit Vote Trades. Consider the following "vote-trading exemplar" illustrating explicit vote trading across two separate cases. ${ }^{99}$ Suppose the Court's docket contains two separate cases, Case Search raising the question whether a particular search violates the Fourth Amendment, and Case Cruel raising the question whether a particular mode of execution violates the Eighth Amendment. The tentative Conference vote in Case Search is 5-4 for the criminal defendant, with Justice Wapner in the majority and Justice Judy in the dissent. The tentative Conference vote in Case Cruel is 5-4 for the state, with Justice Judy in the majority and Justice Wapner in the dissent. Suppose Wapner is close to indifferent about his apparent victory in Case Search, but is very troubled by his apparent loss in Case Cruel; conversely, suppose Judy is close to indifferent about her apparent victory in Case Cruel, but is very troubled by her apparent loss in Case Search. Wapner and Judy then agree to trade votes across the two cases: Wapner switches to vote for the state in Case Search, and Judy switches to vote for the criminal defendant in Case Cruel. From the perspective of each Justice, the trade has improved the overall state of the law; each yiews the trade as creating what he or she considers a minor error but corrects what he or she considers a more major error. Justice Wapner is willing to sacrifice his feasible victory in Case Cruel (the "sacrificed case") for a more meaningful victory in Case Search (the "acquired case"); for Justice Judy, the "sacrificed" and "acquired" cases are reversed.100

It is very difficult to identify clear examples of explicit vote trading. My own sense, in accord with that of other scholars, is that explicit vote trading rarely - and perhaps never - takes place. ${ }^{101}$

99. In theory, Justices might trade votes across two discrete legal issues arising in a single case. I focus on two-case trades because plausible opportunities for such trades are more likely to arise.

100. The Justices might consider the durability of each rule as well as its substantive desirability; the shorter an acquired rule will likely reign, the more its law-improvement value should be discounted.

101. See Robert A. Carp \& Ronald Stidham, The Federal Courts 177 (2d ed. 1991) ("[T]here is virtually no evidence for [logrolling] in the judiciary. Bargaining does indeed take place, but it is more subtle and does not involve vote-swapping."); STEARNS, supra note 1, at 115 ("[A]ppellate courts . . . generally eschew vote trading across issues within cases and across cases ...."); Cohen \& Spitzer, supra note 10, at 84 ("There is 
b. Tacit Vote Trades. On the other hand, my sense (again in accord with others) is that a form of implicit and informal vote trading is common. Sometimes, a Justice - let's again use Justice Wapner - quickly joins a draft opinion circulated by a colleague even though the doctrinal rule articulated does not reflect his sincere position. Justice Wapner nevertheless joins quickly and without criticism, indeed perhaps with praise - because (a) he thinks the error is relatively minor, and (b) he wants to encourage the author to sign onto an opinion in a completely separate but more significant case that Wapner has recently or will circulate soon. ${ }^{102}$

Of course, such tacit back-scratching "agreements" are not formally enforceable. The social norms of cooperation and congeniality prevailing on the Court, however, might strongly encourage a practice of presumptive reciprocity. ${ }^{103}$ Thus, while explicit vote trading seems to be shunned in word and deed, a softer form of tacit trading may well be commonplace. ${ }^{104}$ Either form enables a

precious little evidence of naked vote trading on the Supreme Court."); Mark Tushnet, Themes in Warren Court Biographies, 70 N.Y.U. L. REv. 748, 764 n.86 (1995) (noting his perusal of Brennan's papers over three decades and finding "nothing indicating an explicit 'deal' for votes"); $c f$. PERRY, supra note 81, at 163-65 (reporting interviews with both Justices and law clerks about the certiorari granting process, and observing that with respect to this process "[n] tot a single informant mentioned anything resembling horse trading, and many said explicitly that it never occurred"); Patricia M. Wald, Collegiality on a Court, 40 FeD. BAR NEws \& J. 521, 524 (1993) (referring to intermediate appellate panels, "[b]argaining seldom - I would almost say never - takes place between cases").

102. John Jefferies nicely illustrates this tacit back-scratching practice. Justice Powell, he reports, joined an opinion circulated by Justice Blackmun in a tax case despite Powell's view that the opinion was "lamentable." The reason for the joinder: Justice Blackmun had not yet taken a position on Justice Powell's circulated draft opinion in the much more important affirmative action case Regents of the University of California v. Bakke, 438 U.S. 265 (1978), and as Powell reportedly said, "We don't want to upset Harry in Bakke." JoHN C. JEFFERIEs, JR., Justice Lewis F. Powely, JR. 490 (1994); see also Cross, supra note 9, at 566-67 (suggesting Justices "may quietly and implicitly" engage in such "tacit exchange"); Cross \& Tiller, supra note 97, at 2175 ("One would expect [a judge] who did not care about the issue to defer to [a colleague] who did care about the issue, in anticipation of complementary deference when their roles were reversed.").

103. See Gregory A. Caldeira \& Christopher J.W. Zorn, Of Time and Consensual Norms in the Supreme Court, 42 AM. J. PoL. Scr. 874, 877 (1998) ("Reciprocity is an important norm on the Court, and if a Justice refrains from dissent, he or she may well expect the same treatment in the future from the current opinion-writer."); Forrest Maltzman et al., Strategic and Judicial Choice: New Institutionalist Approaches to Supreme Court Decision-Making, in Supreme Court Decision-Making 43, 56-57 (Cornell W. Clayton \& Howard Gillman eds., 1999) (reporting studies showing that Justices are "likely to engage in tit-for-tat behavior," for example, by "join[ing] majority opinions more quickly if the opinion's author has cooperated with them in the past").

104. See MURPHY, supra note 2, at 52-53 (illustrating such "reciprocal favors"). I suspect that tacit trades are likely to involve smaller error-magnitudes than explicit trades. With a tacit trade the joining Justice cannot be certain her sacrifice will be reciprocated with respect to a specific Other Case (rather than any other one of the joined Justice's choosing). Therefore, she will likely be less willing to make a very large concession than she would if she could guarantee (through an explicit trade) a major concession in return. Recall the example in supra note 102 of Justice Powell allegedly joining Justice Blackmun's "lamentable" tax opin- 
Justice, to some degree, to improve one legal rule at some cost to another. ${ }^{105}$

\section{Normative Constraints on Strategic Voting}

Part II developed prima facie justifications for various types of form-driven and content-driven strategic behavior on multimember courts. Form-driven strategic voting appears relatively uncontroversial; people might disagree over the occasions and extent to which insincere coalition building is desirable as a matter of policy, 106 but there appears to be a consensus that the general practice is legitimate. Content-driven strategic voting engenders much greater controversy. Explicit vote trading is frequently denounced, though generally without clear explanation. The more common but subtle forms of tacit vote trading and Craig-like unilateral maneuvering either are ignored or provoke lukewarm concerns. My strong sense is that there is considerable disagreement about the proper line between acceptable and unacceptable strategic behavior and the reason for drawing it.

One might try to capture the reasons for intuitive discomfort with some categories of strategic voting from two different perspectives. First, one might start with a familiar conception of the solo adjudicatory process and then challenge certain strategic maneuvers as being inconsistent with this conception. The premise here is that the purpose of having multiple instead of single judges - the

ion in the hope Blackmun would reciprocate by joining his Bakke opinion. In the end, Blackmun did not reciprocate, at least in the Bakke case.

105. In Part I, I modelled solo adjudication as if judges decide cases by first determining the optimal legal rules to address the legal issues raised, and then announcing whatever disposition is dictated by fair application of those legal rules. I believe this accurately describes most, perhaps almost all, Supreme Court decisions. But suppose a Justice instead decides cases by first determining the optimal disposition, and then selecting the optimal rule (according to her intrinsic and relational judgment criteria) from among those available that support the preferred disposition. What strategic opportunities would such a Justice face on a multimember court?

Unilateral opportunities arise only when the Justices' sincere positions would lead to a three-disposition stalemate. If only two dispositions are in the running, then each Justice will always maximize the likelihood that his preferred disposition will be the collective choice by voting for it (i.e., voting sincerely for strategic reasons). If three or more dispositions are in play, then a Justice might well decide to vote strategically for his D2 disposition in order to minimize the likelihood that the collective choice will be his D3 disposition. While the choice of the suboptimal disposition is content-driven, the decision can be modelled identically to the form-driven three-disposition deadlock scenario discussed at supra text accompanying note 53. Justices can also improve dispositions through bilateral vote trading. In theory, the trade hypothesized between Justices Wapner and Judy across Case Search and Case Cruel could be driven by each Justice's desire to improve the disposition in one case, even at the expense of a less favorable disposition in the other.

106. See supra note 75. 
teleology of multimember courts - is quite minimalist: it consists simply of creating a deliberative environment, and nothing more. Once deliberation has ceased, each Justice is expected to adjudicate the case according to the same norms that would constrain her decisionmaking even were she sitting alone. ${ }^{107}$ I embrace this minimalist teleology in section III.A, exploring various objections to vote trading and other maneuvers based on familiar solo adjudication norms.

One can instead start with a more robust teleology of multimember courts, which might lead to a different set of adjudicatory norms than those governing judges sitting alone. ${ }^{108} \mathrm{I}$ later consider several alternative teleologies in sections III.B, III.C, and III.D. I proceed in this order for two reasons. First, it makes sense to begin at the beginning, to view the adjudicatory process through the thinnest teleology of collegial courts before exploring the implications of richer teleologies, even if the latter might eventually call into question implications of the former. Moreover, precisely because we have no generally shared account of a teleology of collegial judging or even a robust conversation about one, this part of my inquiry will be even more exploratory and tentative and thus seems appropriately left for last.

\section{A. Solo Adjudication Norms in a Collegial Context}

For purposes of this discussion I take as given certain a priori choices structuring the collegial decisionmaking process, such as majority rule. ${ }^{109}$ I focus primarily on bilateral explicit vote trading,

107. An apt analogy is competitive bowling, a sport playable by individuals or teams. In team bowling, the scores of each team's members are summed, and the team with the higher sum wins. Once each individual toes the mark, she views the activity of bowling just as she would were she competing alone; the same rules, strategies, and other norms apply in each circumstance. The teleology of team bowling thus asks players to behave consistently with the teleology of individual bowling.

108. Here an apt analogy is competitive rowing, another sport playable by individuals or teams. Team rowers are not expected to embrace the same strategies and norms as are solo rowers. For example, a single rower focuses solely on absolute speed; rowers on a team must focus on relative speed as well, lest one side row faster than the other causing the boat to turn. See generally Kornhauser \& Sager, supra note 1, at 3-5 (distinguishing between distributed and team group enterprises).

109. Majority rule is not inevitable. One could readily imagine alternative aggregation mechanisms. Perhaps in each case there could be a single final decisionmaker, either the senior Justice in all cases, the presiding Circuit Court Justice over every case arising from her Circuit(s), a rotating Justice for a fixed term, a randomly selected Justice for each case, a designated "expert" appropriate for the subject matter, or the first Justice to circulate a completed opinion. The relevant single decisionmaker would decide the case and write the sole opinion. By tradition, of course, we employ no such system; we employ majority rule across a set of nine Justices, each of whom has one vote per case. 
and then extrapolate implications to other forms of strategic voting as well as sincere judicial behavior.

\section{Litigant-Focused Constraints}

a. Sacrosanct Disposition Objections. The primary function of even appellate adjudication is commonly said to be resolving a concrete legal dispute between two or more litigants, with the articulation of legal principles being incidental to that task. ${ }^{110}$ Even assuming as I do here that Justices identify governing legal rules first and derive dispositions from them, ${ }^{111}$ one might believe that once the proper resolution of the dispute is identified, the putatively victorious litigant becomes "entitled" to that resolution. As explained by Walter Murphy:

the Justices have an obligation not merely to lay down wise policy to cover all similar situations, but also to guard, to the extent they are able, the rights of the litigants. Protection of the legal rights of litigants is not the only concern of the Court, but it must be a major concern as long as this institution functions as a court of law as well as a policy-making branch of the national government and not solely in the latter capacity. ${ }^{112}$

This view underlies what I call the sacrosanct disposition constraint on strategic behavior: a Justice may vote strategically for a suboptimal rule only if her insincere vote leads to the same disposition as her sincere vote would have done. Legal rules are fair fodder for strategic play, but sincerely derived case dispositions are sacrosanct; a litigant who "deserves" to win (under a sincere voting regime) should not be deprived of victory just to serve lawmaking interests. ${ }^{113}$ In the vote-trading exemplar, for example, both Justices Wapner and Judy violate this constraint because each votes and secures victory for the litigant he or she sincerely believes should lose.

Depending on whether one believes this sacrosanct disposition principle should be unyielding or merely presumptive, a sincere dis-

110. See, e.g., Gary Lawson \& Christopher D. Moore, The Executive Power of Constitutional Interpretation, 81 IowA L. REv. 1267, 1273 (1996); Herbert Wechsler, The Courts and the Constitution, 65 Colum. L. Rev. 1001, 1006 (1965). But see Robert J. Pushaw, Jr., Article III's Case/Controversy Distinction and the Dual Functions of Federal Courts, 69 NOTRE DAME L. REv. 447 (1994) (suggesting federal courts are properly focused more on law declaration than on dispute resolution in Article III "cases," though not in "controversies"). See generally Hartnett, supra note 51 (defending the primacy of judgments over judicial opinions).

111. See supra text accompanying note 21 .

112. See MurPHY, supra note 2, at 187.

113. In other words, strategic voting that alters the sincere disposition makes dispute resolution essentially incidental to judicial lawmaking, contrary to the initial premise that lawmaking is incidental to case deciding. 
position might impose either a "hard" or a "soft" constraint on rule-focused strategizing.

i. Hard Disposition Constraint. The hard version, which holds resolutely that strategic voting cannot alter the disposition, follows the adage that courts should "do justice in the individual case." Many people, were they a litigant in Case Search or Cruel, would be quite disturbed if they would have won had a Justice voted sincerely, but lost because the Justice voted strategically to improve the collective legal rule.

The strength of this underlying intuition, however, can be questioned on its own terms. To begin with, the intuition confronts an interesting temporal question. By hypothesis, strategically improving the legal rule today affects not only who wins the Instant Case but also who will win Future Cases, changing future winners (under the sincere rule) to future losers and vice versa. Why should the entitlement of today's would-be winner under sincere voting trump the entitlement of the future's would-be winner under the strategically secured improved rule? The intuition that courts should respect litigant entitlements when resolving disputes can perhaps be matched by a counterintuition that courts should first define the law in an optimal fashion - whatever methodology that may entail in order best to secure litigant entitlements over the long run.114

Moreover, the intuition seemingly presumes that litigants care more about winning than about establishing favorable legal rules. This is not always so. Some litigants expect to be repeat players in similar Future Cases, and they may be willing to sacrifice a particular victory for a more favorable legal rule over the long run. ${ }^{115}$ Some litigants who do not expect repeat play may nevertheless care more about establishing favorable legal principles than about winning the discrete dispute, either because they are representing

114. Query whether the plaintiffs in the early desegregation cases did or should have supported the Court's "all deliberate speed" remedial edict if they believed it would help their cause in the long run, though it precluded meaningful remediation in the short run. More generally, perhaps people who instinctively flinch at the notion of a dispositionchanging maneuver might feel differently if they were asked about a hard disposition constraint while under a "veil of ignorance," meaning before they knew whether they would be a litigant in the Instant or a Future Case.

115. The government might, for example, care more about setting favorable precedents in criminal procedure cases than about whether it secures a particular conviction. 'This same priority is revealed when a repeat-play litigant, after losing a judgment, offers to settle on terms favorable to her opponent in return for an agreement to vacate the adverse legal precedent. See Judith Resnik, Whose Judgment? Vacating Judgments, Preferences for Settlement, and the Role of Adjudication at the Close of the Twentieth Century, 41 UCLA L. REv. 1471 (1994) (discussing and evaluating this phenomenon). 
others in class litigation ${ }^{116}$ or because they care about the expressive content of the law. ${ }^{117}$

If persuasive on its own terms, the hard disposition constraint would preclude some other common adjudicatory practices besides vote trading. First, the hard constraint contravenes some wellaccepted norms governing solo decisionmaking that lead Justices to support locally suboptimal decisions. Even if Justice Solo's intrinsic judgment criteria incline her to prefer rule R1 leading to disposition $\mathrm{D} 1$, her relational judgment criteria might nevertheless lead her to endorse R2 and D2 either to maintain consistency with, or to compensate for, a Prior Case that she views as wrongly decided. Or, she might decide the Instant Case suboptimally to establish the best long-term precedent for a series of cases. Or, if she prefers rules to standards, she might embrace a rule favoring D2 even though she would decide the case for D1 were it the only one of its kind. In each of these situations discussed earlier, Justice Solo's sincere judgment as to how the Instant Case ought to be decided differs from the judgment she would have reached had her case truly stood alone. Taken seriously, the hard disposition constraint would appear to rule out each of these well-accepted adjudicatory practices.

Now, some readers might stop at this point and protest "that's different; it is perfectly legitimate for Justice Solo to rely on such relational judgment criteria." But this protest begs the question under consideration. The hard disposition objection, by itself, does not render illegitimate strategic efforts to improve the content of legal rules. The "that's different" intuition, strong though it might be, must come from another source.

Second, the hard disposition constraint also rests in tension with some more controversial norms governing solo decisionmaking. As earlier discussed, Alexander Bickel's "passive virtues" sometimes lead Justices to deny favorable judgments to would-be winners; ${ }^{118}$ concerns about public resistance sometimes lead Justices to deny immediate remediation to victorious litigants; concerns about congressional overruling might lead Justices to shy away from sincere rules in a manner depriving a would-be winner from a favorable

116. Cf. Sosna v. Iowa, 419 U.S. 393 (1975) (holding that the named plaintiff has standing to continue representing a certified class despite the mootness of her personal claim).

117. See, e.g., Pildes \& Anderson, supra note 32, at 2204 (submitting that litigants sometimes have a strong interest in the expressive content of an opinion, rather than merely the ultimate disposition).

118. See BICKEL, supra note 37, at 173 ("[T] he policy of avoidance . . . must prevail, despite hardship to the litigant ...."). 
judgment.119 Moreover, consider the recent literature endorsing "metademocratic" canons of statutory construction that are strategically designed to induce a particular short-term or long-term legislative response. ${ }^{120}$ Such canons are designed to shape future legislative decisionmaking in a particular way, not to discern individual entitlements through a "sincere" interpretation of the existing statute. These metademocratic strategies therefore compromise the sacrosanct disposition principle as well. ${ }^{121}$

Third, the hard disposition constraint would appear to rule out form-driven maneuvers in certain contexts. When a Justice strategically forms a majority-disposition coalition to avoid a threedisposition impasse, by definition she votes for a disposition other than her sincere choice. ${ }^{122}$ With respect to strategic voting designed to forge a majority-opinion coalition, a majority might coalesce around a compromise rule supporting the same disposition that each accommodating Justice would have sincerely supported. But this is not always true; sometimes one or more Justices might diverge from their sincere disposition in order to fashion a majority opinion. ${ }^{123}$ The hard disposition constraint would rule out such form-driven maneuvers.

ii. Soft Disposition Constraint. A softer version of the sacrosanct disposition principle holds that a Justice should consider a disposition switch to be a substantial cost of strategic voting, against which the putative benefits of coalition formation or an improved legal rule should be weighed. The intuition here is that, while the Supreme Court (like all courts) decides cases, the articulation of legal precedents is also an important institutional function. Thus getting the judgment right and establishing an optimal rule are both

119. See supra notes 37-38 and accompanying text.

120. See Jane S. Schacter, Metademocracy: The Changing Structure of Legitimacy in Statutory Construction, 108 HARv. L. Rev. 593 (1995) (canvassing and evaluating arguments proposing that courts use various interpretive canons in an effort to mold democratic decisionmaking in desirable ways, such as by interpreting statutes narrowly in order to discipline legislatures to speak with greater clarity).

121. For a provocative argument that such "instrumentalist" interpretive strategies are problematic for precisely this reason, see Bernard W. Bell, Metademocratic Interpretation and Separation of Powers, 2 N.Y.U. J. Leg. \& PUB. Poly. 1, 7-18 (1998-99).

122. One might argue that the apparent necessity of deciding the case through a vote switch trumps the sacrosanct disposition principle, but this abandons the notion that the constraint is "hard." Such a necessity argument also presumes that the Court must decide the case, rather than enter a judgment of "affirmed by a deadlocked Court." See supra note 51 .

123. For example, in the Craig II scenario I hypothesized that Justice Powell, in order to secure the institutional benefits of a majority coalition, might shift from a vote to invalidate the sex-based classification under intermediate scrutiny to a vote to uphold the statute under rationality review. See supra note 89 and accompanying text. 
valued, and when the two goals conflict in a given case a balance may be struck. ${ }^{124}$

Because the soft constraint merely requires a sufficiently strong justification for strategic voting, unlike the hard constraint it is not clearly inconsistent with well-accepted single-judge or multimember adjudicatory conventions. Even the apparently matter-of-course practice of vote switching to avoid three-disposition deadlocks can reflect a high value placed on deciding every case presented to the Court. On the other hand, the soft constraint may be less persuasive on its own terms than the hard constraint. The premise that a litigant is "entitled" to win when the sincere legal rule entails a favorable disposition might strike many as an all-or-nothing proposition. If one buys the premise, it is difficult to understand why this entitlement may be balanced away. If one rejects the premise, it is difficult to understand why the so-called entitlement deserves any weight at all.

\section{iii. Should Individual or Collective Dispositions Be Considered} Sacrosanct? Applying the hard or soft disposition constraint to multimember adjudication confronts an important conceptual ambiguity. Which disposition should a compliant Justice consider fixed: the disposition she would sincerely choose were her vote decisive (the "individual-sincere disposition"), or the disposition that the Court would choose collectively were all members to vote sincerely (the "collective-sincere disposition")? I have heretofore implicitly assumed (following the vote-trading exemplar) that a Justice's deviation from her individual-sincere disposition causes the Court to deviate from its collective-sincere disposition. But this connection is not inevitable; an individual disposition switch might

124. This appears to have been Walter Murphy's view. See MuRPHx, supra note 2, at 188 n.* ("One of the few occasions when this dichotomy [between legal rule and disposition] would raise major problems of ethics in compromise within the Court would be where a Justice would engage in logrolling in the sense of switching his vote on one case where it would change the outcome in exchange for another Justice's switching his vote in a second case. It is possible that the gravity of the two situations would be sufficiently different to make this appear a reasonable choice.").

In weighing the value of law improvement against the disvalue of disposition switching, a Justice would again consider many of the MPE factors described previously. See supra section II.A. In addition, the Justice might focus on the difference in legal effect of the two dispositions under consideration. One might value "outcome moderation," which suggests that a switch from affirm to remand is less troublesome than a more stark switch from affirm to reverse. Or, one might value "settled expectations," which suggests that a switch toward the disposition that would have prevailed had the Supreme Court simply denied certiorari is less troublesome (because it preserves the prereview status quo) than a switch away from that disposition. 
not affect the collective disposition at all.125 If so, is the individual disposition switch still disconcerting - or should only a change in the Court's disposition trigger alarm?

To invoke the sacrosanct disposition principle as a constraint against strategic voting, then, one must first determine whether the disposition should be considered "fixed" from just the individual, or just the collective, or perhaps even both perspectives. And this in turn depends on whether multimember adjudication ought to be conceptualized as an individualistic or collegial enterprise, and precisely what the latter means - in essence, the basic inquiry underlying my project. Thus even if the sacrosanct disposition principle seems intrinsically persuasive, it cannot stand alone outside of a larger conceptual framework.

Identification of the teleology of Court multimembership, for example, might support the choice of a particular perspective for invoking this constraint. The more one thinks group accuracy is an important justification for multimembership, the more sense it makes to privilege the collective disposition over any single Justice's perspective. ${ }^{126} \mathrm{Or}$, one might favor the collective perspective because it appears somewhat more consistent than does the individual perspective with commonly accepted form-driven maneuvers. For example, when viewed from the individual perspective, a disposition switch designed to avoid a three-disposition impasse is troubling; it is prohibited by the hard constraint and disfavored by the soft constraint. When viewed from the collective

125. With respect to bilateral vote trading, one can modify the exemplar as follows. Suppose sincere voting in Case Search would have led a fifth, Justice Mills Lane, to vote for the government on a procedural technicality (say, the criminal defendant waived her Fourth Amendment claim), such that the government would have won. Justice Wapner might still broker a deal with would-be-dissenter Justice Judy, offering to trade her a victory in Case Cruel if she joins him in Case Search to forge a majority-opinion coalition defining Fourth Amendment rights narrowly. If Justice Judy agreed, she would switch from her individual sincere disposition (voting for the government rather than the defendant), but this switch would not affect the collective disposition because the government would have won anyway with Justice Mills Lane's vote (albeit through a fractured opinion).

With respect to unilateral voting, recall Justice Brennan's gambit in the Patterson example discussed at supra note 87 . Brennan temporarily tried to mute the conservative precedential value of the case, through a scheme that required him to vote against rather than for plaintiff Brenda Patterson even though he sincerely thought she should win. Since it was already clear that five Justices would rule against Patterson, his individual switch would not have affected the collective disposition at all.

It is quite possible, therefore, that strategic voting designed to improve legal rules will lead individual Justices to switch dispositions without coincidentally causing the Court's collective disposition to switch. Note that while an individual disposition switch does not necessarily generate a collective disposition switch, there can be no switch in the Court's collective disposition unless at least one Justice deviates from her individual sincere disposition.

126. See infra sections III.B and III.C (presenting models suggesting that multimembership improves collective accuracy). 
disposition perspective, such a disposition switch is less disquieting. Unless one views "affirmance by a deadlocked Court" as a default disposition worthy of protection, ${ }^{127}$ then a collective switch from "deadlock" to any particular disposition seems unproblematic. Conversely, one might disfavor the collective perspective because it is somewhat more difficult to implement in practice. A Justice can easily self-police a sacrosanct disposition constraint from her own perspective, simply by stopping herself before deviating from her sincere disposition. But she cannot as easily police a sacrosanct disposition constraint from the collective perspective, because she cannot always know in advance whether or precisely how her contemplated strategic maneuver will influence her colleagues' votes and hence the collective disposition. Perhaps a more practicable collegial norm would preclude a Justice from contemplating a strategic maneuver that is intended to (rather than actually does in hindsight) stimulate a peer response that alters the collective disposition. In any event, this conceptual ambiguity must be resolved before the sacrosanct disposition constraint can be invoked to rule out a particular set of strategic maneuvers.

b. The Litigant Participation Objection. This objection starts with the premise that adjudication is primarily party-driven, in the sense that the judicial decision is designed to respond to the factual proofs and reasoned arguments advanced by adversarial parties. As most famously put by Lon Fuller:

[T] he distinguishing characteristic of adjudication lies in the fact that it confers on the affected party a peculiar form of participation in the decision, that of presenting proofs and reasoned arguments for a decision in his favor. Whatever heightens the significance of this participation lifts adjudication toward its optimum expression. Whatever destroys the meaning of that participation destroys the integrity of adjudication itself. 128

Concomitantly, the integrity of adjudication also entails a reasoned decisionmaker, one who will respond to and fairly evaluate the reasoned arguments of the parties.

For Fuller, the centrality of litigant participation is essentially definitional: meaningful participation is simply a sine qua non of what adjudication means. But one can view the equation in normative terms. First, participation is valued instrumentally as an important means of ensuring that the court's decision is well-informed. Adversarial presentation of facts and legal arguments, like the pro-

127. See supra note 51.

128. Lon L. Fuller, The Forms and Limits of Adjudication, 92 HARv. L. REv. 353, 364 (1978). 
cess of collegial deliberation, serves to increase the likelihood that the judge will consider all relevant, plausible positions and learn of possible flaws in her tentative reasoning before reaching a decision. Second, litigant participation might be valued intrinsically, on the ground that the parties are "entitled" to participate meaningfully in decisions that directly affect their rights/interests.

Explicit or tacit vote trading partially undermines the meaningfulness of party participation in the Instant Case by introducing an influential element - the Other Case - that cannot readily be identified in advance. Parties present reasoned arguments based on the intrinsic and relational criteria that they predict will, or argue should, be used by the judge. They may easily identify and brief the significance of Prior Cases, both the decisions themselves and the proper weight of consistency or compensation norms attached to them. They also have a fair opportunity to predict what Future Cases the Justices might think are relevant to today's decision, for reasons of consistency or complementarity. ${ }^{129}$

However, parties cannot fairly be expected to anticipate, let alone brief, the entire set of Other Cases that might end up influencing the decision in the Instant Case through a vote trade; that set consists of every other case on the Court's docket. ${ }^{130}$ Moreover, the feature that makes another case a possible trading partner with the Instant Case is not its subject matter, but rather whether two Justices can secure subjective law improvements through trade given the specific matchup of their colleagues' sincere views in both cases. Even assuming arguendo that a party could identify another

129. It is quite common, for example, for parties to advance "slippery slope" arguments of the following form: "The Court should not rule $\mathrm{X}$ today, because such a precedent will lead inexorably to rule $\mathrm{Y}$ tomorrow and rule $\mathrm{Z}$ the next day, and rule $\mathrm{Z}$ is so undesirable as measured by intrinsic criteria that the Court should not start down this path." It is more difficult for litigants today to predict Future Cases that might be complements to today's alternative rules, because complements can spread out in more directions. Still, a party could reasonably predict, for example, the illustrations of complementarity provided earlier. See supra notes 31-32 and accompanying text.

Of course, sometimes Justices do embrace legal theories that were not briefed by the parties, perhaps by spontaneously injecting a "new" issue into the case and resolving it based on self-generated reasoning. See McKoy v. North Carolina, 494 U.S. 433, 446 (1990) (Blackmun, J., concurring) ("It is unusual, but hardly unheard of, for this Court to decide significant legal questions on which the parties have not joined issue."); Barbara Palmer, Issue Fluidity and Agenda Setting on the Warren Court, 52 PoL. REs. Q. 39 (1999) (concluding that Justices on the Warren Court developed new issues in about one-fourth of all cases). Usually, however, in hindsight the Court's approach was at least foreseeable by sharp counsel as a plausible resolution.

130. Indeed, if one considers the most extreme possibility of a bilateral agreement to trade a vote in the Instant Case for an "IOU," i.e., a promise to trade back a vote in an as-yet-unspecified case, the set consists of all cases on the Court's docket now and in the future. The set is equally large for tacit vote trades. 
case that might present trade possibilities, the party could not predict what arguments about that case would help her cause in the Instant Case (either by discouraging an unfavorable trade or encouraging a favorable trade) without predicting with precision each Justice's views in both cases. As a result, decisions influenced by vote trading are arbitrary from the litigants' perspective in the sense that they cannot participate meaningfully, through reasoned argument, in the critical judicial determination - the trading Justices' comparative evaluation of error magnitudes.

This objection drives a wedge between explicit or tacit vote trading and other forms of strategic behavior, because it is triggered only by the connection of logically unrelated cases. When Justices engage in unilateral content-driven maneuvers such as the Craig scenario, and all form-driven maneuvers, they focus their attention on the substantive issues raised in the Instant Case and related cases, not on unforeseeable Other Cases. If they so choose, parties can even devote some of their argument to the question of whether a specific-sized majority coalition is desirable for the particular issues involved. Indeed, if the Instant Case presents multiple issues, the parties can even choose to discuss the comparative importance of the issues such that they can guide the Justices's consideration of any possible bilateral trade among those issues. Only bilateral vote trading across separate cases starkly raises the specter of arbitrariness that frustrates meaningful party participation.

Whether this objection is powerful enough to explain the consensus antipathy toward vote trading, however, turns on the significance one attaches to meaningful party participation through the presentation of reasoned arguments. The more central one views this role on either instrumental or intrinsic grounds, the more troubling vote trading becomes. But the more one disagrees with Fuller and believes instead that party-driven adjudication, while perhaps a good idea, is not normatively essential, then the less troubling vote trading becomes. At the far extreme, if one views parties as helpful but noncrucial judicial assistants, then the Justices' resort to decisionmaking means beyond the parties' ken is not that disturbing at all. Recall that even vote trading does not devalue or ignore litigant participation entirely; it just values some nonparticipatory aspects of reasoning as well, much as does sophisticated voting that considers in part the views of nonjudicial actors. ${ }^{131}$

131. See supra section T.A.2. 


\section{Reasoned Justification Constraints}

This section explores a series of related objections as applied, at least initially, to bilateral trading. Each objection reflects a theme common to many jurisprudential paradigms: when Justices declare what the law is en route to deciding cases, we expect them to base that declaration on reasoned argument of a certain form.

a. Adjudication as a Justificatory Practice. Many respectable jurisprudential paradigms hold that adjudication is, first and foremost, a justificatory practice. According to this view, the legitimacy of courts' authority turns on the fact that adjudication is a forum of justification or reason giving, in a way that other forms of decisionmaking are not. ${ }^{132}$ If a judge does not have a reasoned justification for a legal decision, she has no legitimate claim to the exercise of coercive authority over the litigants. ${ }^{133}$ As a result, we are rightly hostile to any adjudicatory practice that undermines the process and integrity of justification, even if that practice in some sense "improves" the doctrinal rules ultimately produced. Process, not result, is paramount.

With this process focus in mind, one might challenge explicit and tacit vote trading as depriving the two traded decisions of the type of reasoned justification necessary to judicial legitimacy. After all, there seems to be an element of arbitrariness to the decisionmaking in both involved cases. In the vote-trading exemplar, for example, Justices Wapner and Judy do not take each of Cases Search and Cruel into account when deciding the other one because the result in one case influences their sincere rankings of the available rules in the other. Rather, they take the Other Case into account only because of the happenstance that, given the particular lineup of all nine Justices in both cases, there is an available trade that both believe improves the set of results. If Justice Wapner were asked why he voted the way he did in Case Search, he could not provide a complete answer without mentioning the role played by Case Cruel. While this reference would partially "explain" his

132. See, e.g., Fuller, supra note 128 , at 366 :

Adjudication is, then, a device which gives formal and institutional expression to the influence of reasoned argument in human affairs. As such it assumes a burden of rationality not borne by any other form of social ordering. ... We demand of an adjudicative decision a kind of rationality we do not expect of the results of contract or of voting.

133. See Richard H. Fallon, Jr., "The Rule of Law" as a Concept in Constitutional Discourse, 97 Colum. L. REv. 1, 18-19 (1997) (describing a legal process conception of the "rule of law" as requiring, inter alia, a "reasoned elaboration of the connection between recognized, pre-existing sources of legal authority and the determination of rights and responsibilities in particular cases"). 
decision, on the surface it would hardly seem to "justify" it, at least in any sense familiar to the judicial enterprise.

But reliance on familiarity here is dangerous, precisely because multimember decisionmaking may enable novel but still legitimate notions of justification. Viewed in isolation, Wapner's decision in Case Search seems unprincipled; he has seemingly "sacrificed" this case for law improvement elsewhere. But why view Case Search in isolation? The mere possibility of bilateral vote trading essentially allows a Justice to vote on two issues at once as a packaged deal, an option generally unavailable to judges sitting alone. ${ }^{134}$ Consider Justice Wapner's approach to the vote-trading exemplar. Wapner sincerely supports Rule S+ over Rule S- in Case Search and Rule $\mathrm{C}+$ over Rule $\mathrm{C}$ - in Case Cruel, but if everyone votes sincerely the Court will endorse Rule S+ in Case Search and Rule C- in Case Cruel. Wapner can trade across the two cases with Justice Judy, meaning he can control whether the Court produces rules $\mathrm{S}+\& \mathrm{C}$ (by voting sincerely) or rules S- \& C+ (by trading). Put differently, Wapner can change the relevant "choice set" from a choice among single rules to a choice among rule combinations.

As illustrated earlier, Wapner can employ the "magnitude of perceived error" rubric to reason from his jurisprudential premises to the conclusion that he prefers package $S-\& C+$ to package $S+\&$ $\mathrm{C}$-. His MPE assessment leads him to view collective outcome S- as a lesser error than collective outcome C-; he is therefore willing to endure the former to forestall the latter. $\mathrm{He}$ is not merely appraising the two combinations to see which he prefers in some troubling result-oriented sense. Rather, he is employing the very same process of reasoning that led him to prefer S+ over S- and C+ over Cin the first instance. ${ }^{135}$

134. But see supra note 38 (describing theoretical opportunity for lower court judges to bundle issues through strategic protection against overruling).

135. Some might find it helpful to recast this argument from the perspective of a Justice whose jurisprudential paradigm is that of a Dworkinian coherence theorist. See generally RoNald DWorkIN, Law's EMPIRE (1986). Viewing Case Search in isolation, Justice Hercules would rank the available doctrinal rules according to their "integrity," that is, their consistency with the best set of principles that can justify the most of existing outcomes. The "right" answer is that with the greatest integrity so measured. The other answers can be ranked according to how far removed they are from the ideal; an answer that is fundamentally inconsistent with foundational legal principles will be worse than an answer that is merely in tension with a weaker or lower level principle.

Viewing Cases Search and Cruel as a package, Justice Hercules can still rank each of the possible combinations of answers according to their "integrity." Of course, assuming no relational judgment criteria link the two issues, the best combination of rules will be the best Fourth Amendment rule plus the best Eight Amendment rule, S+ \& $\mathrm{C}+$. But Hercules can still rank the imperfect alternatives, and his coherence model will provide a reason to favor 
To be sure, the comparison of rule packages rather than individual rules is unfamiliar. But why would this reasoning process, deemed legitimate when used to favor one rule over another, suddenly become illegitimate when used to prefer one rule package over another? It cannot be problematic just because Wapner finds neither package ideal. This complaint would have too far-reaching consequences, as judges frequently must choose between two or more imperfect options when the optimal option is not feasible to secure. ${ }^{136}$ And it cannot be problematic just because there is a sense in which, in evaluating the MPEs associated with S- and C-, Wapner might be comparing "apples and oranges" if the two issues draw upon very different underlying principles. First, it is unclear whether such an apples-and-oranges comparison should be troubling from a theoretical standpoint. ${ }^{137}$ But in any event, this complaint would also have too far-reaching consequences, as judges frequently must compare fundamentally different principles in ranking alternatives. ${ }^{138}$

Let us return to the initial claim here, that concern for cabining illegitimate assertions of coercive judicial authority dictates hostility toward any adjudicatory practice that undermines the process and integrity of justification, even if that practice in some sense "improves" the doctrinal rules ultimately produced. It is true that vote

one imperfect combination over the next, e.g., package $S-\& C+$ over package $S+\& C$ - over package S- \& C-.

136. See, e.g., supra notes $28-30$ and accompanying text (tradeoff between intrinsic and relational criteria, where Justice Solo must rank the imperfect alternatives of maintaining consistency with an erroneous precedent or correcting the error but undermining consistency); supra text accompanying note 64 (tradeoff between the imperfect alternatives of voting sincerely and fracturing the Court versus forging a coalition for a suboptimal position); cf. Schauer, supra note 18, at 869-70 ("[P]erhaps that very striving for the optimal is not part of what law is, and maybe law, more positivistically conceived, is at bottom a second-best solution, seeking to optimize in the long term in a world in which the attempt to optimize in the short-run may yield an unacceptable number of short-run errors.").

137. Perhaps coherence theorists are used to resolving discrete legal problems by invoking a single or connected set of local or intermediate principles to justify the decisions in a discrete, unified realm of law-for example, drawing upon only Fourth Amendment principles to decide a novel Fourth Amendment issue. In theory, however, the requirement of coherence or integrity applies to the entire set of legal materials, such that prioritizations and accommodations among seemingly different intermediate principles are attainable. But cf. Joseph Raz, The Relevance of Coherence, 72 B.U. L. REv. 273, 297-314 (1992) (criticizing "global coherence accounts" and defending "local coherence," meaning coherence of doctrine in discrete fields of law). If the objection to vote trading turns on the distinction between global and local coherence, then surely the unreflective condemnation of vote trading is undertheorized.

138. See, e.g., supra notes $28-34$ and accompanying text (tradeoff between intrinsic and relational criteria, where Justice Solo must compare the substantive values underlying the merits to rule-of-law values such as stability and predictability); supra text accompanying note 64 (tradeoff between the substantive values underlying the merits and structural values secured by particular coalitions). 
trading is generally described in terms of improved results, not proper process. But a Justice can provide the same type of justificatory explanation for a trade as for a single-issue ranking: the outcome chosen best satisfies his intrinsic and relational criteria taking relevant MPEs into account. The only difference is that the Justice in a vote-trading scenario ranks combinations of rules rather than single rules. This distinction does not appear to make the ranking process any less an exercise in reasoned justification. ${ }^{139}$

One might nonetheless argue that the different ways of conceiving the choice set matters with respect to adjudicatory norms relating to explanation rather than justification. The next two sections consider other norms arguably undermined by vote trading: candor and noncommodification of judgments.

b. The Candor Objection. The majority opinions issued in Cases Search and Cruel will, on their face, exemplify the reasoned elaboration of legal principles rather than reveal themselves as the product of a strategic deal. To be sure, the reasoned argument that would have appeared as a dissent without the trade now appears as the opinion of the Court, and vice versa. But, assuming the trading Justices do not reveal the trade themselves, no one outside the Court should be able to detect whether the Fourth Amendment decision was influenced by the Eighth Amendment or any other decision. Thus one cannot complain that there is no publicly articulated, internally coherent justification for either majoritybacked rule. One might, however, complain that for one of the joining Justices this justification is merely a charade.

Explicit and tacit vote trading would appear to lead a Justice to endorse openly a justification different from her true motivation the MPE calculation. Thus decisionmaking through vote trading violates an oft-proclaimed norm of judicial candor. ${ }^{140}$

This presumption of candor is frequently justified on the ground that it disciplines judicial reasoning. The act of reducing one's true thought processes to written form stimulates critical self-scrutiny, and the act of publication enables peers and the public to evaluate

139. One might view tacit vote trading as somewhat more troubling than explicit vote trading in this respect. With a negotiated trade, both Justices self-consciously engage in a precise evaluation of comparative MPEs, an analysis grounded in legal principle. The Justice initiating a tacit trade by joining a suboptimal opinion in the Instant Case must engage in a more speculative analysis, because he does not know for sure the precise reciprocal benefit he will receive. While his decision to initiate the informal trade still reflects principled reasoning about the comparative value of legal rules, the uncertainty involved makes the reasoning process seem somehow less rigorous and more conjectural.

140. See, e.g., Shapiro, supra note 47. 
and hold individual Jüstices accountable for their decisions. This both improves decisionmaking generally, and also makes it less likely that impermissible factors will play a role, either subconsciously (because the writing requirement may help to identify such subconscious motives) or consciously (because impermissible motives might be difficult to "write around"). ${ }^{141}$ Vote trading partly avoids these disciplining and constraining effects of transparency, because the driving force behind a Justice's decision to trade - his comparative MPE assessment of the two rules involved - is not revealed, let alone publicly explained and justified. Thus in the explicit vote-trading exemplar, Justice Wapner avoids both the discipline of forced writing and public accountability for the cost-benefit judgments comparing these particular pairs of Fourth and Eighth Amendment rules. Similarly, the joining Justice engaged in a tacit vote trade avoids revealing his even more speculative cost-benefit analysis.

Second, an obligation of candid opinion writing is frequently justified on the ground that it enhances the judiciary's legitimacy in the public eye. In the long run, some assert, a general suspicion that judges dissemble when articulating and applying rules of law will tend to diminish popular respect for judges and their decisions, thus eroding the judiciary's de facto authority. ${ }^{142}$ The argument here is at least partially prophylactic: if Wapner may falsely endorse arguments in Case Search for this particular (hypothetically laudable) purpose, he may feel empowered to do so for more disturbing reasons - or so the public might reasonably fear. ${ }^{143}$

These justifications for candor carry some analytical and rhetorical force, though their tangible effects are highly speculative. This said, deciding just how much force to give to such an objection is difficult. If embraced as a rigid constraint, the obligation of transparency would call into question a number of adjudicatory practices

141. See id. at 737; Gulati \& McCauliff, supra note 13, at 193-94. One might quibble about the extent to which candor truly constrains judicial decisionmaking. First, given the plasticity of law, frequently Justices can "plausibly justify" multiple positions. Second, while Justices might be somewhat sensitive to criticism by their colleagues, rarely will a Justice "receive any sort of critical attention" by members of the public "that might get back to the judge and alter his future behavior." POSNER, supra note 4, at 127. Moreover, perhaps other internal norms and institutions propel Justices towards reasoned decisionmaking, rendering a candor requirement largely superfluous. But for present purposes I accept the conventional wisdom that candor matters to some important degree.

142. See, e.g., Shapiro, supra note 47 , at 737.

143. See Edwards, supra note 40 , at 1369 (emphasizing the importance of public perceptions of judicial behavior); Kornhauser \& Sager, supra note 18, at 92 (noting that decisionmaking processes can be judged by their "tendency ... to inspire belief among those affected by the resulting decisions that those decisions are proper"). 
besides vote trading. Some sophisticated behaviors, including many of Alexander Bickel's "passive virtues," involve judicial dissembling. Moreover, many uncontroversial form-driven strategic maneuvers designed to forge coalitions of various sizes entail the suppression of sincere views - indeed, that is the whole point of forming unanimous-opinion coalitions. Finally, content-driven strategic maneuvers such as the unilateral Craig exemplar, while generally thought less controversial than bilateral maneuvers, entail the same misleading acts. Justices engaging in these practices typically do not either concede deviation from their sincere views or provide the reasons therefor. Indeed, taken seriously the obligation of candor might require each Justice to write separately in each case.

Recognizing the tension between absolute candor and these various non- or less-controversial judicial practices, scholars championing transparency generally endorse a more flexible presumption rather than a rigid duty. "Certainly, the art of compromise is not out of place in the halls of justice. An effective judge must have a sense of when to settle for less than his heart's desire, either in writing his own opinion or in joining someone else's."144 But this concession invites a difficult line-drawing inquiry: How should a Justice balance the virtues of candor against the virtues of strategic suppression or misdirection in the Instant Case? David Shapiro has posited that a judge should "not materially mislead the reader."145 Others have proposed somewhat different though equally vague standards. ${ }^{146}$ Perhaps the line might appropriately be drawn differently at different points in the evolution of judicial practice; in the early Republic, for example, Chief Justice John Marshall clearly believed that individual candor through sincere seriatim opinions would undermine rather than enhance the Court's prestige and authority, but 200 years' experience with judicial review may well mollify this concern..$^{147}$ In any event, the important point is that candor is generally considered a presumption, not a fixed con-

144. Shapiro, supra note 47 , at 743.

145. Shapiro, supra note 47 , at 743 n.54; see also id. at 743 ("[T]he sticking point can and should be an unwillingness to make or join in a statement that does not represent the judge's views and that will mislead the opinion's readers as to what those views are.").

146. Cf. Kornhauser \& Sager, supra note 1, at $7 \mathrm{n.12}$ ("The exact limits of appropriate judicial behavior are difficult to articulate.").

147. Compare Marshall's early views on the importance of solidarity, see supra note 71 , with Scalia's, see Scalia, supra note 75, at 35 (concluding that solidarity is no longer so important for preserving the Court's prestige and authority "at its current stage of development and in the current age"). 
straint. ${ }^{148}$ As such, the candor objection to vote trading and other maneuvers leaves open an argument in the Instant Case that the tangible law-improving benefits of strategic voting outweigh the incremental and speculative loss of judicial discipline, accountability, and credibility.

Of course, one could approach the candor objection from a different angle, conceding its force but deflecting it by encouraging Justices to be open about their vote-trading practices. While transparency would defeat the very purpose of certain strategic maneuvers (such as forged unanimity to create the appearance of solidarity), it would not fatally undermine the law-improvement objective of vote trading. ${ }^{149}$ Perhaps the public's awareness of vote trading would itself undermine its respect for the judiciary; if so, then a lack of candor might be justified as a sophisticated ploy to avoid public disfavor. But the premise that open vote trading would diminish judicial respect, equally speculative as the claim we started with that dissembling would breed disrespect, remains undefended as of yet.

In the end, it is difficult to decide how much weight to give the candor objection to vote trading. In general, the candor constraint is more persuasive when viewed as a presumption than as an absolute. The question with vote trading, as with all of the other forms of judicial reasoning that involve dissembling to some degree or another, is whether the benefits in terms of furthering judicial goals is worth the cost. On this point, reasonable minds might reasonably disagree, and perhaps for many the answer will not turn on the particular type of strategic maneuver but rather the particular issue raised by or the context surrounding the Instant Case. ${ }^{150}$

148. See Shapiro, supra note 47 , at 738 (positing that arguments against dissembling do not "demonstrate the need for candor as an unshakeable rule of judicial behavior").

149. An explicit vote trade could be revealed in two obvious ways. First, the trading Justices could explain their own insincere votes in separate concurrences. Second, the Court as a collective entity could reveal the vote trade, perhaps by explaining the trade through a per curiam opinion. Neither method of vote-trade revelation would undermine the authority of the rules articulated in either of the traded cases, and hence neither would be selfdefeating.

It is more difficult to imagine complete candor from a Justice initiating a tacit vote trade. He would have to both admit insincere support for the rule in the Instant Case, and express hope that he receives a more-valued concession from the author in a Future Case. He cannot readily provide a full explanation of his comparative MPE evaluation, for he cannot identify the second case with certainty. In contrast, the reciprocating Justice can be candid because, coming second, she can identify both traded rules.

150. One might purport categorically to distinguish between vote trading (both explicit and implicit) and all unilateral maneuvers on the ground that observers cannot even identify the issues being compared through an MPE assessment with a vote trade, whereas they can at least identify the concerns being compared with both form-driven strategies (the issue's merits versus institutional benefits) and content-driven strategies (just the issue's merits). 
c. The Commodification Objection. This objection posits that adjudicatory processes have expressive as well as functional significance, and argues that bilateral vote trading as a means of rule development undermines the ideal of adjudication as principled reasoning. Goods and services - including adjudication - can be produced, distributed, and used through various social processes, such as markets, political ordering, and spontaneous or uncoordinated activity. A number of scholars have forcefully argued that the particular manner in which goods and services are produced and distributed has expressive consequences for the ways in which those goods and services, as well as the creators and users, are perceived and valued. ${ }^{151}$ More pointedly, these scholars suggest that the "commodification" of certain (heretofore uncommodified) goods and services, meaning the regulation of their production, distribution, and use through market regimes, threatens to alter in troubling ways our valuation of both persons and things. ${ }^{152}$

Vote trading can be described in crass transactional terms. A Justice essentially uses the MPE assessment to ascribe a value to a given legal error (the difference between $\mathrm{R} 1$ and $\mathrm{Rn}$ ), and then decides whether it is worth trading for an unrelated legal correction. Legal rules (more precisely, errors of legal rules) or judicial votes can be characterized as goods or services to be bartered within a judicial marketplace. Such commodification of rules or their production might alter or deform our shared cultural understanding of adjudication and its role in securing the rule of law, by superimposing on adjudication a preexisting set of cultural norms associated with market activity. ${ }^{153}$ Or so many might intuitively fear; markets and adjudication, the intuition runs, do not mix.

See supra text accompanying note 130 (making the same point in discussing litigantparticipation objection). But this distinction, while perhaps relevant to the public perception concern, is not fully responsive to the discipline and accountability concerns. The apprehension that, absent pressure to articulate her thoughts comprehensively, a Justice might more frequently take positions that are poorly reasoned or ad hoc or reflect impermissible factors applies whenever any aspect of a decision is left unexplained. After all, the failure to discuss even the seemingly mundane question of why she feels coalition-building is sufficiently important to justify insincerity in one case but not the next raises all of these concerns. In this respect, then, the difference between vote trading and other maneuvers seems one of degree and not of kind.

151. See, e.g., Eltzabeth Anderson, Value in Ethics and Economics (1993); MARgaret Radin, ConIEsted Commodities (1996); see also ANDERSON, supra, at 218 (suggesting a need to "consider whether the ways we produce and exchange goods adequately express the other ways we properly value them or one another").

152. See, e.g., ANDERSON, supra note 151, at 168-216 (applying critique to various issues concerning women's labor and environmental cost-benefit analysis); RADIN, supra note 151, at 131-53 (applying critique to prostitution and baby selling).

153. See ANDERson, supra note 151, at 144-47, 145 (describing the norms structuring market relations as having five features: market attitudes are "impersonal, egoistic, exclu- 
To assess the strength of this objection, we must parse more carefully the fear of commodification in this context. Precisely what cherished ideals of and attitudes towards adjudication might be threatened, and why would their loss be so troubling? One might worry that a market orientation towards judicial decisionmaking could shape the following attitudes tracing prevalent market norms: (1) what matters is the set of rules produced, not the process or quality of their production; (2) judicial rulings are essentially private rather than public goods; ${ }^{154}$ (3) legal judgments articulating what is right and just can be compared to all sorts of "less exalted" goods and services, through a common metric of monetization; (4) judicial decisions direct the exercise of coercive authority according to comparative wants, desires, or preferences rather than a clash of principles; and (5) Justices should act autonomously, perhaps even antagonistically, rather than cooperatively with each other.

In the abstract, these are serious claims. To my mind, however, the practice of vote trading as I've described it would not seriously threaten such profound alterations of social meaning. We are not talking here about a "literal" market, in which Justices exchange a commodity (viewed either as the "good" of a legal rule or the "service" of voting a certain way) for tangible currency. At the very

sive, want-regarding, and oriented to 'exit' rather than 'voice.' . . [These norms] express a shared understanding of the point and meaning of market relations recognized by every experienced participant.").

Scholars sometimes resist commodification through market imagery on the ground that the metaphor can have a "domino effect" of sorts by changing actual practices to conform to the underlying imagery. See RADIN, supra note 151, at 13-14, 95-101. But such an effect seems unlikely here. I doubt anyone would claim that vote trading of the sort I've described might eventually give way to a literal market in which Justices exchange votes for money or opera tickets.

One can, I suppose, construct somewhat more plausible slippery slopes. For example, what if Justice Judy said to Justice Wapner, "I will support your position in Case Cruel, even though I disagree with it, if you promise to retire from the Court at the end of the Term." Because Judy believes that Wapner generally creates legal errors in important cases, Wapner's replacement would likely improve the law in a long-term, global sense. In a loose sense the "currency" of this trade remains legal principle and such a trade strikes me as more principled and less commodified than a straightforward exchange of votes for money, but yet might still be more disconcerting than the vote-trading exemplar.

154. This concern underlies a common objection to the judicial practice of enabling parties to settle cases on appeal with one of the settlement terms being the vacatur of a lower court precedent. See supra note 115 . This practice comes close to the construction of a market in which losing litigants can "purchase" and then purge their adjudicatory loss, which undermines the social construction of precedents as public goods. See U.S. Bancorp Mortgage Co. v. Bonner Mall, 513 U.S. 18, 26 (1994) (declining to implement settlement calling for vacatur of an appellate opinion with precedential significance, in part because judicial precedents are public goods and "not merely the property of private litigants"); Resnik, supra note 115, at 1526-32 (discussing vacatur practice with respect to the "meaning of courts as institutions"). 
most, we are talking about a "metaphorical" market.155 The bartering of commodities is merely imagery, not reality. This should not end the normative inquiry, of course, ${ }^{156}$ but just as surely it makes a big difference. ${ }^{157}$

In the vote-trading exemplar, Justices trade votes based on their reasoned (though divergent) assessments of the rightness of two collective outputs. The "currency" of exchange is legal principle, not the traders' own or the litigants' preferences or desires. There is a sense in which two independent products, the rule in the sacrificed case and the rule in the acquired case, are appraised for their relative value. But Justices appraise and compare the relative value of competing rules or justificatory positions all the time, without engendering a sense of problematic commodification. ${ }^{158}$ Thus the comparative valuation of two judicial products, in and of itself, does not appear to involve a troubling commodification. True, vote trading adds an element of bilateralism to the picture, certainly more consistent with market imagery. The mere involvement of two people in a mutual exchange, however, does not necessarily conjure up the image of commodification in the sense that only results rather than processes and commitments matter. ${ }^{159}$

Because vote trading is dictated by Justices' rather than litigants' views, it does not suggest that the good produced is private rather than public in character. As modelled earlier, the motivation

155. See RADIN, supra note 151, at 1-2, 12-15 (describing and distinguishing between "literal" and "metaphorical" markets).

156. See id. at 83-93 (raising concerns potentially posed by metaphorical commodification).

157. It appears to make such a difference in the context of legislative activity. The practice of "vote buying" through political bribery, literally a citizen-driven market, is universally condemned. See Pamela S. Karlan, Not by Money but by Virtue Won? Vote Trafficking and the Voting Rights System, 80 VA. L. REv. 1455 (1994); Richard Hasen, Vote Buying, (unpublished manuscript, on file with author). In contrast, the practice of legislative logrolling, though not without its critics, is generally tolerated. Trading votes for and against different proposed bills simply does not seem to commodify legislation in the same way as would open vote buying by the citizenry or legislators.

158. For example, when a Justice resolving a single issue confronts intrinsic and relational judgment criteria that pull in opposite directions, he must value and compare the strength of the vectors. See supra notes $28-34$ and accompanying text. And when a Justice considers whether to vote insincerely to forge a majority-opinion coalition, he must appraise and compare the value of one feasible collective product (a fractured Court articulating his sincere position among others) with another (a unified coalition supporting a nonoptimal legal rule). See supra text accompanying note 64.

159. Consider a parent who promises his schoolchild that, if she studies hard and improves her test scores, he will treat her to a day at Disneyland. Some might find resort to this parental technique disconcerting, pejoratively considering this a bribe. Yet the economic element does not drive out space for competing social understandings as well; the same act entails and expresses such values as parental concern, familial communication, academic dedication, a desire to please others, and mutual respect. 
behind vote trading is law improvement as measured by one's jurisprudential paradigm rather than preference satisfaction with regard to personal ideology or policy goals. As practiced, it does not utilize a common currency suggesting that judicial decisions are "on a par" with seemingly more mundane and tangible commodities. And it need not conjure up an image of Justices acting with indifference or antagonism towards each others' views, rather than acting with a cooperative spirit to produce the optimal overall set of rules and justification therefor. ${ }^{160}$

Concededly, social meaning reformulation is not an on-off switch, and commodification can range on a continuum from complete to less-complete forms which "bear some indicia of commodification but are more attenuated."161 Thus even if one agrees that the vote-trading exemplar is a far cry from a prototypical market exchange, she might still be somewhat troubled by indicia of commodification still remaining. The question is whether a qualm that vote trading might undermine a worthy ideal of adjudication by superimposing on it a set of market-based norms is sufficiently strong to justify a strict anticommodification rule. I would not think so, but I recognize both that others might disagree and that analytical argument cannot wholly resolve the dispute.

\section{Judicial Lawmaking Constraints}

This final set of solo adjudication-based objections revolves around a common intuition: vote trading crosses a conceptual or even constitutional line dividing adjudication and legislation. At one time this intuition might have been captured by the claim that courts "declare" rather than "make" law, and that focus on lawmaking is an ultra vires judicial function. A more sophisticated and modern version would propose that, in a meaningful sense, courts do make law, but do so in a peculiarly judicial manner. ${ }^{162}$ Some-

160. See the example provided in supra note 159.

161. RADIN, supra note 151, at 117. Thus, for example, one might argue that the "indicia of commodification" are even more "attenuated" for tacit than for explicit vote trading. While the participants engage in an informal trade, there is no explicit bartering process in which they simultaneously compare their relative valuations of nongermane rules. The trade is still based on the rational calculations of each Justice, but it feels less like an economic exchange and more like the informal tit-for-tat relationship of neighbors, each of whom does favors for the other based on the expectation that the other will respond in kind within a reasonable time such that the relationship is mutually beneficial.

162. See James Beam Distilling Co. v. Georgia, 501 U.S. 529, 549 (1991) (Scalia, J., concurring):

[The judicial power] is "to say what the law is," not the power to change it. I am not so naive (nor do I think our forebears were) as to be unaware that judges in a real sense

"make" law. But they make it as judges make it, which is to say as though they were 
thing about vote trading makes it seem as though Justices are making law in an inappropriate manner, and therefore, the practice transgresses the proper boundaries of adjudication.

This intuition might be parsed in various ways; courts are frequently charged with "acting like a legislature," with the accusers meaning different things. Many of the conventional bases of accusation can be dismissed summarily, either because the claim is unpersuasive or because it does not apply to vote trading, or both. ${ }^{163}$ Four charges deserve more attention.

a. The Legislative Association Objection. We generally associate vote trading with legislative activity. A common defense of vote trading in legislative bodies (there called "logrolling") is as follows (with defenders disagreeing on some of the particulars). The aim of the legislative enterprise is to promote preference satisfaction. By trading votes across discrete issues on the agenda, legislators reveal the relative intensities of their preferences (or the preferences of their constituencies) with respect to the set of issues under discussion. ${ }^{164}$ The weighing of relative intensities of the support and opposition to a particular legislative proposal is a normatively

\footnotetext{
"finding" it - discerning what the law is, rather than decreeing what it is today changed

to, or what it will tomorrow be.
}

(citation omitted).

163. One common accusation of "judicial legislating" charges that a particular Justice has based her decision in a case on nonlegal factors, such as her personal values and policy preferences. This charge is inapt here; in the scenarios under discussion, vote-trading Justices rest their decisions on their intrinsic and relational judgment criteria supplemented with a magnitude of perceived error assessment.

A second common refrain is that judges "act like legislators" when they articulate a detailed and complicated doctrinal formula, such as Roe's trimester distinctions and Miranda's detailed police warnings. This charge is conceptually weak, for the reasons explained in Maxwell L. Stearns, Standing Back from the Forest: Justiciability and Social Choice, 83 CAI. L. Rev. 1309, 1390-92 (1995), and David A. Strauss, The Ubiquity of Prophylactic Rules, 55 U. CHI. L. Rev. 190 (1988). In any event, it is inapt here; traded rules can be simple or detailed just as sincere rules can be simple or detailed, and there is no reason to suspect any connection between trading and complexity.

A third frequent refrain is that judges "act like legislators" when they pronounce legal rules unnecessarily, either by ignoring the case-or-controversy requirement, by reaching issues that are not necessary to resolving the dispute, or by making sweeping statements of dicta. All three phenomena ignore the injunction that courts, unlike legislatures, should not set their own agenda. See Stearns, supra, at 1389 ("Not only are courts limited to and by actual cases in their lawmaking capacity, but in deciding cases, they are generally expected to abstain from creating positive law unless necessary to resolve the case before them."). This concern is also inapt here; there is no necessary connection between vote trading and agenda setting. In the vote-trading exemplar, for example, I have assumed that the rules traded across Cases Search and Cruel are rules necessary to the decision in both disputes. There is no good reason to think that Justices engaged in vote trading would ignore intrinsic judgment criteria dictating narrow or cautious decisionmaking any more than those not so engaged.

164. See, e.g., William J. Baumol, Welfare Economics and the Theory of the STATE 45 (1965) ("[L]og-rolling transforms voting from a procedure which takes into account only ordinal preferences into one which can reflect the strength of feeling."). See generally James M. Buchanan \& Gordon Tullock, The Calculus of Consent 131-45 (1962) 
defensible method of aggregating votes; rather than necessarily identifying the "decision 'preferred by most members," the method identifies the "decision "most preferred by members." "165

Some people find judicial vote trading intuitively illegitimate, I believe, because they mentally associate the practice with the more familiar phenomenon of legislative logrolling. Based on this connection, they wrongly assume that the rationale for judicial vote trading would mimic that for legislative vote trading, and they (rightly) find the preference-satisfaction rationale anathema to judicial reasoning. The first assumption is wrong because, as explained in section II.B, judicial vote trading can be supported by reference exclusively to legal concepts and principles, and without necessary resort to problematic objectives such as preference satisfaction. Upon reflection, therefore, the instinctive and disconcerting mental association between judicial and legislative vote trading provides no normative foundation for criticizing the judicial practice.

b. The Forward-Looking Law-Creation Objection. Some might object that vote trading feels legislative in nature because it seems to focus on forward-looking law improvement rather than backward-looking law interpretation. "Law improvement" sounds like a legislative task, whereas faithful interpretation of exogenously provided law, whether that law seems good or bad, sounds like an adjudicative task.

This way of characterizing the judicial lawmaking constraint is rhetorically powerful. However, it ignores the significant extent to which well-accepted interpretive practices already contain a forward-looking, improvement-oriented element to them. As explained earlier, relational judgment criteria require Justices to look forward as well as backward, to select a rule that is optimal over a run of related cases even if it might be suboptimal for the Instant Case viewed in isolation. The consistency criterion, for example, requires Justices to envision the Future Cases in which today's rule might apply and to fashion a rule today that traces the optimal trajectory. Similarly, Justices such as Scalia whose intrinsic judgment

(modelling legislative logrolling); Robert A. DahL, A Preface to Democratic Theory 90-123 (1956) (discussing issues raised by variable intensities).

165. Willmoore Kendall \& George W. Carey, The "Intensity" Problem and Democratic Theory, 62 AM. Pol. ScI. Rev. 5, 6 (1968).

Whether this defense of vote trading is persuasive or not is the subject of a sizable political theory literature. $C f$. DAFI, supra note 164, at 119 (arguing that no enduring solution exists to the problem in democratic theory of whether relative intensities ought to be weighed). As a normative matter, the practice of legislative logrolling is generally accepted, even if sometimes begrudgingly. See Buchanan \& Tullock, supra note 164, at 140. 
criteria favor bright-line rules over standards self-consciously choose rules that will optimally govern the run of cases to which they will apply in the future. ${ }^{166}$ Of course, Justices employ such a forward-looking analytical lens as a means of fashioning law to resolve a dispute that has already occurred (and the decision is in this sense backwards-looking), whereas legislation is generally designed prospectively to govern events that have not yet transpired. But like these well-accepted interpretive approaches, vote trading also employs forward-looking law-declaration techniques to make backward-looking judgments about existing disputes. Unless we are significantly to revamp our approach to conventional solo interpretation, therefore, it cannot be merely the forward-looking nature of vote trading, or its professed goal of improving the law, that crosses the line between adjudication and legislation.

c. The Comparative Competence Objection. A third objection deserves even greater consideration. I start with the premise that, like legislatures, appellate courts "create" law in the loose sense in that they routinely engage in forward-looking reasoning to "improve" doctrinal rules or sets of related rules. ${ }^{167}$ Unlike legislatures, they do not set their own agenda as to when they issue rules governing what substantive issues. ${ }^{168}$ Nevertheless, their project certainly the Supreme Court's project - is to decide the cases presented to them by fashioning rules that are optimally adapted to govern future as well as the current disputes.

This objection adds the following premise: due to institutional distinctions between courts and legislatures, the goal of competency in lawmaking requires courts to employ a different lawmaking methodology than do legislatures. Legislatures are comparatively well-designed to consider and study societal problems comprehensively, and to devise optimal forward-looking solutions thereto. Congress, for example, has factfinding resources, access to expert advisers, and control over its own decisionmaking timing, and each feature is nicely suited to competent forward-looking planning. In contrast, courts are not structured to be as proficient at seeing far into the future, or at perceiving and comprehensively considering

166. See supra note 30 .

167. See POSNER, supra note 4, at 131 ("Many cases cannot be decided by reasoning from conventional legal materials. Such cases require the judge to exercise a legislative judgment, although a more confined one than 'real' legislators are authorized to exercise.").

168. Given the Supreme Court's certiorari discretion, the Court has close to plenary power to set its agenda negatively in the form of a decision not to hear a particular case or issue. But the Court still lacks affirmative agenda control because it cannot create a vehicle for deciding a particular issue; it must await one. 
all of the ramifications and interests affected by proposed doctrinal rules. ${ }^{169}$ While certainly helpful, amicus and Brandeis briefs are not dependable substitutes for the legislative process. Perhaps more significantly, the doctrine of stare decisis makes it more difficult for courts to reverse their direction if subsequent events reveal a misstep. 170

Given these observations, the argument continues, we have much more confidence in Justices' ability to develop optimal forward-looking rules when the Justices focus their attention on fashioning a direct response to the facts and context of the dispute before them, rather than when they engage in a self-conscious project of abstract law improvement. I do not mean to suggest here that Justices are more competent or trustworthy at determining results rather than rules, although some may take this view as well. ${ }^{171}$ I mean rather that Justices are better at fashioning case-tethered rules than they are at fashioning rules in the abstract. This casefocused tethering or mental discipline is what gives us some confidence in the soundness of judicial rulemaking, to the point where we have sufficient confidence in a rule forged under these constraints that we are willing to give it significant (though not rigid) future effect via stare decisis. ${ }^{172}$ But we ought to get very nervous when judges, even appellate judges, get so focused on "law improvement" that they consider cases to be mere convenient occasions for abstract lawmaking rather than focal points for legal reasoning. In short, we are rightly concerned that courts are much less likely really to "improve" the law when they lose sight of and wander mentally away from the context, facts, and litigants in a particular case. Therefore, the objection concludes, vote trading (and perhaps other strategic maneuvering) is problematic because it encourages Justices to engage in abstract rather than case-tethered

169. See Steven D. Smith, Courts, Creativity, and the Duty to Decide a Case, 1985 U. ILL. L. REv. 573, 594 ("Critics of judicial creativity assert that courts lack the informationgathering ability, the representative base, the time and administrative resources, and the political wisdom to make policy.").

170. See Frank Easterbrook, Stability and Reliability in Judicial Decisions, 73 CoRNell L. Rev. 422, 423 (1988) (noting the tension between stare decisis and the benefit of hindsight).

171. See Philip B. Kurland, Polmtics, the Constrtution, and the Warren Court 94 (1970) (quoting Lord Mansfield as advising "new judges to state their judgments and withhold their reasons, since their judgments were probably right and their reasons probably wrong"); Cass, supra note 13, at 992 (noting that the common law's traditional "preference for incrementalism reflects the view that rationales become less trustworthy guides to future decisions the more they extrapolate from the base of known fact-settings to which they apply").

172. See Anthony Kronman, The Lost LAWyer 318-19 (1993). 
reasoning, even as they properly attend to forward-looking law improvement.

While the premise of this objection - that courts should remain focused on contextualized decisionmaking - is both analytically and rhetorically powerful, ${ }^{173}$ the deduction that vote trading violates this norm demands greater scrutiny. First, each of the two cases involved in a vote trade satisfy the normal requirements for concreteness and adverseness. The trading Justices (and the rest), therefore, start from a factbound, contextual setting and can reason outward when they construct their initial rankings of, and assess their magnitudes of perceived error for, the proposed rules in each case. In the vote-trading exemplar, for example, both Justice Wapner's and Justice Judy's rankings of proposed rules governing the search and punishment issues will be fully informed by the precise nature and context of the two disputes as well as the facts and legal arguments developed by the litigants. There is nothing in the methodology of vote trading that should affect these aspects of judicial reasoning; both the trading and nontrading Justices follow the same analytical path to their rankings in the individual cases.

One might characterize the next reasoning step in the votetrading process - the comparison of MPEs in the two cases - to be somewhat abstracted from the case contexts. When Justice Wapner considers whether the perceived sacrifice in Case Search is more than compensated by the perceived improvement in Case Cruel, he might ponder some seemingly abstract questions like the following: Is it more important for wrongful death sentences to be avoided than for wrongful privacy invasions to be allowed? This question (and others like it) is not tethered to a specific case. And yet, Justice Wapner would certainly be aware of how his answer to this question would ultimately affect his vote and therefore the disposition of these two concrete cases with identifiable parties. In other words, the case-specific consequences of his abstract reasoning would be readily perceptible, at both intellectual and visceral levels. This remains a far cry from the sort of abstract legislative rulemaking against which the judicial practice is being measured.

Moreover, this sort of abstraction seems implicated even by the less-controversial forms of strategic maneuvering. Consider, for ex-

173. It is not, however, beyond question. See Frederick Schauer, Giving Reasons, 47 STAN. L. REv. 633, 655-66 (1995) ("Although there may be good reasons to worry about the distorting effects of uninformed speculation, there may be equally good reasons to worry about the distorting effects of decisionmaking overinformed by the grip of a particular instance."). 
ample, form-based strategic voting designed to forge a majorityopinion coalition. A Justice must construct a ranking of rules on the merits, assess the importance of solidarity in the context of the case, and then compare the strength of the two vectors. This latter comparison is no more or less "grounded" in the underlying case than the comparison of MPEs across two cases is grounded in the vote-trading scenario.

Perhaps a slightly different concern animates the comparative competence objection. One might argue that the acceptance of vote trading as a legitimate practice will lead Justices to shift the way they approach adjudication in all contexts, involving vote trading or not. Perhaps consideration of potential vote trades will, over a period of time, encourage Justices to focus their attention more and more on the forward-looking law-improvement aspect of adjudication and less and less on the backwards-looking case-deciding function. In other words, the more Justices start thinking about adjudication in terms of optimal rulemaking, a mental perspective facilitated by the constant search for potential gains from trade, the more they will become emboldened to make less case-tethered and context-disciplined decisions generally. This, again, moves them away from their arena of special rulemaking competence.

This feared transformation is certainly not fanciful; indeed, some might think Justices are already prone to the disease of imagining themselves as unconstrained lawmakers and thinking about litigants as inconvenient obstacles. But neither is the transformation inevitable. Surely one can imagine that, even as Justices selfconsciously engage in vote trading, they also remind themselves of the importance of self-disciplined focus on case contexts, facts, and parties. The question becomes whether, as a prophylactic measure, a norm against vote trading should be articulated and internalized to forestall the risk of a concomitant shift in the Justice's selfunderstood job description. In my view, the prophylactic seems unnecessary, but I recognize this is a subjective and speculative judgment.

d. The Complementary Task Objection. The comparative competence objection presumed that, in contradistinction to legislative bodies, courts are better at contextual rather than abstract lawmaking. But even if one believes that courts can engage in abstract lawmaking as competently as can legislatures (in other words, dismissing the assertion of legislative superiority due to institutional design), one might still not want courts to do so. Perhaps there is a virtue in having two different institutions engage in two different 
but complementary types of rulemaking - one taking a broad, prospective view and the other taking a narrow, case-centered view.

One might differentiate between legislative and judicial lawmaking in two distinct but related respects. First, leaving comparative competencies aside, it might be desirable to have one governmental institution make abstract judgments and another make contextualized ones. Second, it might be desirable to have one make global determinations about large areas of the law, and have the second make focused decisions about narrow aspects of the law viewed in isolation from one another, in essence "unbundling" the global package. ${ }^{174}$

Optimal rulemaking is difficult, and both courts and legislatures can make mistakes. But, this argument continues, the likelihood of ultimate error might be reduced if problems are approached from two different perspectives. If judges act too much like legislatures in the sense of making abstract and global decisions, then society loses a unique benefit of a dual set of complementary lawmaking functions.

Much of my assessment of the comparative competence objection applies here as well. It is unclear whether, to any appreciable extent, an accepted practice of vote trading would lead Justices to focus any less on the contexts and applications of alternative rules in each of the two involved cases. And while it is true that vote trading involves "bundling" two rules together for packaged consideration, this notion is not unique to this practice. As explained earlier, Justice Solo essentially considers two or more rules or rule applications together whenever she invokes a relational judgment criterion in resolving the Instant Case. ${ }^{175}$ Moreover, a trading Justice still considers the desirability of each rule in isolation, before concluding that a trade will result in an overall improvement of the law.

Of course, the "overall" here means that each trading Justice is willing to sacrifice optimality in one particularized, local realm of law in exchange for improving another. One might still therefore object that vote trading is inconsistent with an institutional teleology of optimizing local responses to discrete issues, in juxtaposition

174. Legislatures frequently consider various issues together in single bills, either in an effort to deal comprehensively with an issue or as a result of logrolling. One might want an independent body, when addressing these issues, to separate particular parts of laws from each other and particular applications of laws from each other.

175. See supra notes 28-34 and accompanying text; see also note 34 (noting that relational criteria can generate multiple equilibria in rule optimization, where Justice Solo is perfectly indifferent between two sets of complements). 
to a legislative focus on optimizing the big picture. But this objection begs an important question concerning how one defines "local" law improvement. Consider the vote-trading exemplar. While Justice Wapner views the move from R1 to R2 in Case Search as a sacrifice, Justice Judy views the same move as an improvement. From the Court's collective perspective, then, whether the vote trade worsens or improves the Fourth Amendment rule presents a difficult question. The answer ultimately turns on whether one should count each Justice's comparative judgment equally (in which case more Justices than not view the move from R1 to R2 as worsening the local rule), or should weight their intensity of conviction (in which case Judy's conviction of rule improvement may outweigh Wapner's concession of rule sacrifice). I consider this aggregation quandary in secion III.B.3. If one views the weighted-intensity approach as appropriate, then vote trading appears to improve both local rules at issue. If so, then the practice does not eradicate the benefits of having two separate lawmaking institutions make law at different levels, wholesale and retail.

\section{B. Accuracy Through Pure Redundancy}

Section III.A assumed a minimalist teleology for multimember courts, and explored how and when certain norms traditionally thought to govern solo decisionmaking might prohibit Justices from engaging in vote trades or other strategic maneuvers. This section and the two that follow approach strategic voting from the top down, considering whether particular conceptions of the teleology of multimember adjudication might argue against these practices. Here I posit that the basic purpose of multiplicity is to enhance the accuracy of the Court's collective product.

\section{The Redundancy Theorem}

It is conventionally assumed that at least one, if not the central, purpose for multimembership on an appellate court is to enhance the accuracy of the collective product. The motivating premise is that judges reach divergent answers to legal questions because of human error; even good judges sometimes make mistakes.

On a single-judge court, every error of the sole judge translates directly into an error of the court with case-disposition and ruleprecedential significance. On a collegial court, however, redundancy within a majority-rule regime minimizes the impact of individual judgment errors on the Court's output. Indeed, the more judges there are, the more likely the majority-winning position will 
be correct. An intuitive proof of this axiom is quite simple. If there are three judges choosing between rules $A$ and $B$, the court will reach the "correct" result (let's say A) even if one judge errs and chooses B. If there are five judges, the court will reach the correct result even if two judges err and choose $B$. And so on. Rigorous mathematical models lead to the more refined conclusion:

It will . . . be true for a fixed number $N$ of judges that as the probability of each judge's reaching a correct decision increases, the probability of the panel's arriving at a correct decision also increases. Moreover, if each judge is more likely than not to reach a correct decision, then, as $N$ increases, the probability of the panel's reaching a correct decision also increases. ${ }^{176}$

This phenomenon might be called the "theorem of redundancy theorem": multiplicity with majority rule enhances the likelihood of group accuracy by overwhelming individual errors.

\section{The Redundancy Theorem Applied}

a. A Sacrosanct-Majority Principle. Because Justices occasionally confront multiple rather than binary alternatives in a given case, the definition of an "accurate" group decision is somewhat ambiguous. Obviously, if the Justices confront a binary choice between $A$ and $B$, the position supported by majority rule is properly deemed "accurate" because the redundancy theorem makes it more likely to be so than the option receiving minority support. If the Justices confront multiple options A . . n and a majority embraces a single option, say $\mathrm{A}$, then the redundancy theorem still supports the accuracy of that collective choice. ${ }^{177}$ Thus, once a majority of the Justices' sincere views converge on a decision, that majority-

176. Kornhauser \& Sager, supra note 18, at 99 . For proof, see $i d$. at $97-99$, and sources cited in id. at 98 n.20. See also I.J. Good \& Gordon Tullock, Judicial Errors and a Proposal for Reform, 13 J. LEGAL STUd. 289, 291-94 (1984).

The basic model assumes that, on average, each Justice on the Court is more likely than not to reach the "best answer" to every legal question. Even if different Justices have varying degrees of probability of reaching the correct answer, the probability of the group majority being correct still increases as the group gets larger so long as the average accuracy rate exceeds $50 \%$. See Bernard Grofman \& Scott L. Feld, Rousseau's General Will: A Condorcetian Perspective, 82 Am. Pol. Sci. Rev. 567, 570 (1988). Note that while redundancy with majority vote enhances accuracy, depending on the vote, it does not come close to guaranteeing it. See, e.g., Good \& Tullock, supra, at 293-94 (noting that for example, under a certain set of assumptions, with a 5-4 vote "the probability that the Court's decision is wrong is at least 37 percent").

177. Because $A$ receives more votes than the combined sum of its competitors, $A$ is more likely accurate than not-A, let alone than any individual competitor.

When judgments can be issued in terms of numerical values, then individuals' answers need not be identical for their choices to "converge" on a single choice through an arithmetic mean. Consider judges at an Olympics diving event, each of whom scores each dive on a 1-10 point scale based solely on her sincere assessment of the dive. Suppose there are five judges, and each dive is scored according to the mean of the individual scores, e.g., 9.25. This tally, 
supported decision can be deemed "accurate." Any strategic maneuver that will guide the Court to a different collective choice is inconsistent with this collegial teleology. This "sacrosanct-majority principle" constrains every type of strategic maneuver in certain contexts.

Applied to vote trading, this principle rules out any trade that would undermine a majority position in either case. Thus the votetrading exemplar would be excluded, since there existed a pretrade majority-opinion coalition in both Cases Search and Cruel. But this is not always true; depending on the pretrade pattern of sincere voting, a trade may not undermine any sincere-majority positions. ${ }^{178}$

The same constraint governs unilateral strategic maneuvering, but its application is more nuanced. Consider the Craig I scenario, which supposed that, had Brennan voted sincerely for his R1 strict scrutiny, the Court would have remained split into three minority factions supporting different rules. By voting strategically for his R2, Brennan created a majority for intermediate scrutiny without undermining a sincere-majority position for any rule. The majoritysacrosanct principle does not bar this maneuver.

The Craig II scenario is trickier. That scenario supposed that, had Brennan voted sincerely for his R1 strict scrutiny, Justice Powell would have provided a fifth vote for rational basis scrutiny because he was strongly form-driven to forge a majority-opinion coalition. Prior to Brennan's gambit a majority coalition supporting his R1 intermediate scrutiny was not a feasible alternative, and Powell preferred to build a majority coalition for rational basis review than to vote sincerely and splinter the Court. But Brennan's strategic vote for intermediate scrutiny enabled Powell to support that rule as well and to forge a majority coalition for his sincerely preferred position. Brennan's strategic gambit therefore shifted the collective outcome from a majority coalition for rational basis scru-

despite an arguably artificial convergence, is more likely to be an accurate collective judgment of the dive than is any other.

Sometimes judges may likewise select from a set of numerical choices arrayed along a spectrum, for example, the determination of compensation awards in civil cases, or fines and imprisonment terms in criminal cases. But these types of choices are rarely presented to multimember panels; usually such decisions are left to single-judge trial courts. For an intriguing exploration of strategic voting opportunities in such rare contexts, see Omri Ben-Shahar, Strategic Behavior in Judicial Panels (June 1992) (unpublished manuscript, on file with author).

178. For example, suppose that sincere voting in both Cases Search and Cruel leads to three minority factions supporting a left view, a middle view, and a right view. Members of the left faction in Case Search might agree with members of the right faction in Case Cruel to vote for the middle in both cases. This trade would create a posttrade majority for the middle position in both cases, without undermining a sincere-majority position in either. 
tiny to a majority coalition for intermediate review. However, since Justice Powell actually preferred the second outcome to the first, it is dubious whether the apparent sincere majority for rationality review (including Powell's begrudging vote) should be considered sacrosanct under the redundancy rationale. In my view, it is difficult to say that either of the two Craig scenarios is barred by the sacrosanct-majority principle.

The sacrosanct-majority principle also informs the application of the disposition-constraint principle discussed in section III.A.1. That principle posited that strategic voting should not alter the sincere disposition in a case, but was ambiguous as to whether the disposition to be considered fixed should be the maneuvering Justice's own sincere disposition or the Court's collective-sincere disposition. The pure redundancy model suggests that the latter should control, because it explains why the Court's collective-sincere disposition is more likely to be accurate than the Justice's personal disposition. ${ }^{179}$

Finally, the sacrosanct-majority principle does not severely constrain form-driven maneuvers. By definition, insincere voting to construct a majority-disposition or majority-opinion coalition does not undermine a preexisting majority position. The principle would constrain insincere voting to construct a unanimous-opinion coalition only in the extreme case in which the unanimous agreement would diverge from a sincere-majority position. ${ }^{180}$

b. Further Possible Extensions. If sincere voting would produce no majority winner but would produce a plurality-supported position, an interesting ambiguity results. In one sense, the redundancy theorem does not privilege the plurality position because a majority of the Justices thought this position wrong. But in another sense, the plurality position is still more likely than any other option to be accurate. ${ }^{181}$ If one takes the latter perspective and holds that plurality positions should be privileged as "accurate," then the redundancy model places even further constraints on strategic voting. Specifically, a sacrosanct-plurality principle would hold that strategic voting cannot undermine a sincere plurality by creating a trumping majority for any competing alternative. ${ }^{182}$

179. This conclusion follows as well from each of the other two collegial models operationalizing the teleology of accuracy, discussed in infra sections III.B.3 and III.C.

180. See supra note 72.

181. See Kornhauser \& Sager, supra note 18, at 99.

182. Strategic voting that converts the sincere-plurality into a winning majority position is, of course, acceptable. 
To illustrate, if sincere voting produces a 4-3-2 split over rules $A$, $B$, and $C$, respectively, then Rule $A$ should be considered privileged. The pure redundancy model permits a vote trade with another case if it forges a majority for $\mathrm{A}$, but not if it creates a majority for B or C. Similarly, the model permits a unilateral strategic maneuver creating a majority for rule $\mathrm{A}$, but not for either $\mathrm{B}$ or C. ${ }^{183}$ Finally, the sacrosanct-plurality principle constrains formdriven strategic voting more than did the sacrosanct-majority principle. Justices may vote strategically in order to forge a majority or larger opinion coalition for A, but not for either B or C. Relatedly, if the sincere vote creates three minority factions for different dispositions, Justices may avert a deadlock by switching to outcome A, but not $\mathrm{B}$ or $\mathrm{C}$. Note that this constraint on form-driven maneuvers is nontrivial, since as explained earlier it is not inevitable that coalitions would naturally form around the plurality disposition and thus render the constraint irrelevant. ${ }^{184}$

If the pattern of sincere votes fails to produce either a majority or plurality winner, there is no convergence on an outcome that the redundancy theorem privileges as "accurate." Nonetheless, preserving a spectrum of top-ranked positions through a ubiquitous sincere-voting requirement might be lauded on various grounds. It would enable litigants to predict better how the Justices individually (and thus the Court collectively) will approach related issues in future cases. ${ }^{185}$ Moreover, the public's ability to "count heads" to determine the true weight of judicial opinion on a given matter may strongly influence the public's own perception of the legal principles at stake. ${ }^{186}$ Deviations from sincere positions obscure such signals.

183. This conclusion holds whether some sincere supporters of A shifted to B or C, or whether some sincere supporters of B or C shifted to the other.

184. The point of convergence depends on the Justices' rankings. It is certainly plausible that the original supporters of rules (or outcomes) B and C would converge on one of those two rules (or outcomes) and leave the original plurality winner in the minority position.

185. See supra note 75 .

186. Sometimes the Justices themselves use head counting as a means of supporting their positions. See, e.g., Planned Parenthood v. Casey, 505 U.S. 833, 912 n.1 (1992) (Stevens, J., concurring in part and dissenting in part) ("In the last 19 years, 15 Justices have confronted the basic issue presented in Roe v. Wade, 413 U.S. 113 (1973). Of those, 11 have voted as the majority does today .... Only four - all of whom happen to be on the Court today - have reached the opposite conclusion."); see also Meredith Kolsky, Note, Justice William Johnson and the History of the Supreme Court Dissent, 83 GEO. L.J. 2069, 2085 (1995) ("[K]nowing the number of Justices who dissent from an opinion and how they disagree will inform people's views about the legitimacy and force of the opinion."). Such revelations are meaningful only if there is good reason to think that the articulated positions are sincere. 
One might still permit Justices to vote strategically in minor degrees, such that the degree of obscurity is low. I think such a balance underlies some scholars' suggestions that Justices may vote insincerely so long as they do not "materially" or "significantly" misstate their true views. ${ }^{187}$ This is obviously a fuzzy constraint. In the Craig hypothetical, for example, is moving from strict to intermediate scrutiny a material deviation? Does that depend on how many hypothesized Future Cases the two rules would decide differently, or should materiality be defined in some other manner? Compared to other constraints generated by the pure redundancy model, this constraint's application is far more subjective.

Even leaving this last extension aside, one might plausibly argue that the model's sacrosanct-majority and sacrosanct-plurality principles justify a prophylactic rule barring all strategic maneuvers. This is because, at the time one or more Justices consider a strategic maneuver, she may not know how a purely sincere vote would come out, and thus not know for sure whether her strategic gambit would undermine a majority or plurality winner. ${ }^{188}$ The cost of such a prophylactic rule is the loss of some law-improving maneuvers that would not, in hindsight, have actually steered the Court away from a collectively accurate determination.

\section{Questioning the Redundancy Premise: The Propriety of Intensity Weighting}

The pure redundancy model described above aggregates individual judgments into a collective one through a specific mechanism: each Justice's vote in a given case counts the same, and each Justice must vote once. ${ }^{189}$ Informally, of course, a Justice can always underweight his own vote by deferring to a colleague whose judgment seems more sure or. who cares more about the issue. ${ }^{190}$

187. See, e.g., Shapiro, supra note 47, at 743 n.54 ("Perhaps here, and elsewhere, the [candor] restraint should require that the judge not materially mislead the reader.").

188. In the vote-trading exemplar, for example, Justices Wapner and Judy may recognize the trading opportunity across Cases Search and Cruel and begin negotiating even before it is clear whether or not the final postdeliberative sincere-collective vote in either case would generate a majority-backed outcome.

189. There appears to be an unwritten convention that, unless recused, a Justice may not vote to "abstain" on grounds of either incertitude or equipoise.

190. See, e.g., POSNER, supra note 4, at 123 (noting that on a three-judge panel if "one judge has a strong opinion on the proper outcome of the case ... the other judges, if not terribly interested in the case, may simply cast their vote with the 'opinionated' judge"); $c f$. PERRY, supra note 81, at 169 ("[I]f three Justices feel strongly that cert. should be granted, sometimes I will give a fourth vote. I will say that if you all feel that strongly, I will vote with you on that." (quoting an unnamed Supreme Court Justice discussing the cert. petition process) (internal quotation marks omitted)). 
But the model officially ignores the fact that Justices may have different strengths of conviction or degrees of certitude, and a Justice who is confident that R1 is much better than R2 will be perfectly counterbalanced by a colleague who hesitantly believes that R2 is barely better than R1. Assuming that votes should be equally weighted, vote trading violates simple majority rule and thus undermines the supposed virtue of pure redundancy in improving collective accuracy.

The premise that Justices' votes should be equally weighted, however, has been assumed rather than expressly defended. One might posit instead that group accuracy is enhanced when the Justices' votes are differentially weighted to reflect varying strengths of conviction and certitude. This alternative premise arguably blunts the pure redundancy objection to vote trading; indeed, this premise actually provides an affirmative justification for strategic behavior that reveals comparative intensities in the Instant Case.

Let me be clear: I am not talking about intensities of preference, intensities of feeling, or of other such variables sometimes invoked to justify intensity-sensitive aggregation schemes in political or economic spheres. This adjudicatory model focuses exclusively on a Justice's comparative intensities of judgment about the rightness of a legal answer. In some cases, a Justice's intrinsic and relational criteria will lead her to confidently perceive one rule as significantly superior to its competitors, and in other cases they will make her unsure how to rank two rules that appear in virtual equipoise. ${ }^{191}$

While perhaps the notion of intensity-sensitive calculations is less familiar in the context of judgments than preferences, the notion is certainly coherent. To be sure, such calculations seem unhelpful in contexts where judges' certitude and convictions about error are unlikely to vary much. Suppose three basketball referees are asked whether a potentially game-winning shot was launched before time expired. If all three had an equal vantage point, it is difficult to see why their individual judgments should be weighted unequally: their judgments are equally credible and they perceive the same stakes. But now suppose referee Amanda had a signifi-

191. In his study of the certiorari-granting process, H.W. Perry confirmed the general proposition that Justices vary in their degrees of conviction: "Each Justice seems to have certain areas, large and small, where he feels strongly about how doctrine should proceed or, for some reason, cares strongly about the outcome of a particular case. It may well be something about which the rest of the brethren are dispassionate." PERRY, supra note 81, at 280. 
cantly greater vantage point such that she was absolutely certain of the right answer, and referees Betty and Charlie were both uncertain. Would it not make sense for Amanda's judgment to have greater sway in the collective decision ${ }^{192}$

And consider situations in which judges differ not in certitude but in conviction about error magnitudes. Suppose NASA plans a moon landing and asks three astronomers to determine the optimal rocket trajectory. Astronomers Amanda and Betty say, "The right answer is $X$, but if you instead use $Y$ the rocket would miss the target by only a mile, and that does not threaten the mission." Astronomer Charlie says, "The right answer is $Y$, but if you instead use $\mathrm{X}$ as Amanda and Betty suggest, the rocket would fly past the moon entirely." Given these judgments and accompanying magnitudes of perceived error, couldn't common sense justify choosing $Y$ over $\mathrm{X}$ even though the majority thinks $\mathrm{X}$ is a slightly better answer?

The question remains, of course, whether intensity sensitivity is a desirable way to measure accuracy in the judicial context. Some scholars have suggested that where issues of justice are concerned, equally weighted voting seems appropriate because, out of fairness, no person's views of justice ought to count for more than her neighbor's. ${ }^{193}$ But the fairness rationale seems to stem from democratic impulses concerning questions of self-government, and even in that realm, the rationale is subject to question. ${ }^{194}$ It is not clear that such a fairness rationale applies to courts, at least if one views Justices as trying to identify accurate judgments rather than representative ones. At the very least, rejection of judicial intensity weighting on this ground rests on a controvertible proposition that some democratic criterion has a role to play in judicial decisionmaking. If one focuses solely on group accuracy, however, then weighted-intensity voting has much to commend it.

Of course, as political scientists and economists have reported in other contexts, comparative intensities are difficult if not impossible to measure directly. Theorists have proposed various theoretical

192. Which is what actually happens in professional basketball: a referee with a clearer vantage point will often "overrule" her colleagues if they are less sure of their judgment.

193. See, e.g., Pildes \& Anderson, supra note 32, at 2133-34 (describing this view).

194. See Sherman J. Clark, A Populist Critique of Direct Democracy, 112 Harv. L. Rev. 434 (1998) (direct democracy distorts popular input by precluding the expression of relative priorities among issues); Jeremy Waldron, Legislation, Authority, and Voting, 84 GEo. L.J. 2185,2211 (1996) (noting that while "according equal weight ... to individual votes is a way of respecting persons," it does not follow that "either fairness or equal respect for persons requires majority decision"). 
ways in which to measure group members' relative intensities over a specific decision, but all are subject in different ways to application difficulties. ${ }^{195}$ The relevant question here is whether certain forms of strategic voting provide a plausible way of detecting and incorporating comparative individual intensities into a collective judgment of accuracy.

Consider bilateral vote trading first. A single trade alone, such as the vote-trading exemplar involving Cases Search and Cruel, is not a trustworthy barometer for the Justices' intensities in each of those cases. ${ }^{196}$ But a rich market for trades should (assuming away significant transaction costs) result in a reasonable aggregation of weighted intensities in every case. ${ }^{197}$ Thus the collegial teleology of accuracy, coupled with the specific premises of the weightedintensity model, suggest that explicit vote trading is an appropriate

195. For a general description of several "positional" methods of voting taking relative intensities into account, see MUELLER, supra note 65, at 113-22; RIKER, supra note 53, at 8194. Different methods measure relative intensities differently, however, and self-reporting methods can generate biases and strategic manipulation. See Pildes \& Anderson, supra note 32 , at 2134.

196. We cannot be sure that the aggregate intensities of Case Search's posttrade majority exceed the aggregate intensities of the posttrade minority. Suppose the pretrade lineup was Wapner plus A, B, C, \& D for the criminal defendant, and Judy plus X, Y, \& Z for the State. The posttrade line-up is A, B, C, \& D for the defendant and Wapner, Judy, plus $X, Y, \&$ Z for the State (who now wins). It is conceivable that $A, B, C, \& D$ are very certain the posttrade Court is making a big mistake, and $\mathrm{X}, \mathrm{Y}, \& \mathrm{Z}$ are both unsure and ambivalent. Thus, even after the trade, the aggregate intensities supporting the losing criminal defendant might still outweigh the aggregate intensities supporting the winning State.

197. Consider again the previous example in supra note 196. In a rich market, one or more of $A, B, C, \& D$ would have been motivated and likely able to strike a deal with one or more of $\mathrm{X}, \mathrm{Y}, \& \mathrm{Z}$ to trade this case back to the criminal defendant in exchange for a reciprocal trade, such that the result in this case would in fact mirror the hypothesized relative intensities among the Justices.

Some political science literature suggests that, under certain circumstances, vote trading to promote preference satisfaction can reduce overall group utility. See, e.g., William H. Riker \& Steven J. Brams, The Paradox of Vote Trading, 67 AM. Pol. Scr. Rev. 1235 (1973). See generally Thomas Stratmann, Logrolling, in Perspectives on Public Choice Theory 322 (Dennis Mueller ed., 1997); id. at 322 ("Today, no consensus exists in the normative public choice literature as to whether logrolling is on net welfare enhancing or welfare reducing ...."); Hasen, supra note 157, at 18-22. One important aspect of this analysis - whether mutual trading gains perceived by legislators impose welfare-reducing externalities on third parties - is inapplicable to the judicial context, where the currency of trade is legal principle rather than preference satisfaction and thus the same externality does not arise. Still, this literature at least raises the question (beyond my capacity to answer here) whether judicial vote trading might still lead some cases to be decided suboptimally, as measured by the sincere intensities of the Justices. Of course, the prevailing regime of equally weighted voting also will occasionally produce this result. It is difficult to imagine how one could measure whether a trading regime would, on balance, produce more accurate decisions taking intensity into account.

Even if this objection provides a persuasive contemporary policy argument against vote trading, it cannot account for the longstanding intuitive antitrading norm. Surely many judges and scholars denouncing vote trading have been unaware of this relatively recent, and still somewhat contested, finding of political scientists. Rather, their intuitive objection necessarily rests on a more accessible foundation. 
means of enabling Justices to express their relative intensities en route to enhancing the accuracy of their collective judgment in any given case.

Tacit vote trading is based on the initiating Justice's assumption that she will later receive a reciprocal insincere joinder that results, from her perspective, in overall law improvement. Given the lack of express bargaining, however, there is some chance of miscalculation. Perhaps the recipient of her joinder in the Instant Case will reciprocate on an issue that, in hindsight, she will view as a smaller concession than the one she initially gave. If this happens too frequently, of course, she will likely refrain from tacit trading in the future. One would expect, therefore, that while some individual informal trades may turn out not to be mutually beneficial, a general regime of tacit trading would flourish only if on the whole Justices believe it reasonably reflects their relative intensities over issues.

Whether the weighted-intensity model supports unilateral maneuvers such as the Craig hypothetical is a more difficult question. Justice Brennan's gambit reflects the fact that, according to his MPE assessment, he feels so strongly that his $\mathrm{R} 3$ rationality review is wrong that he is willing to deviate from his $\mathrm{R} 1$ and support R2 in an effort to avert the strongly disfavored outcome. The resulting coalition for intermediate scrutiny thus reflects, in part, the strength of his anti-R3 conviction. Because this move does not reflect a complete market, it is more difficult to claim that the resulting majority coalition more strongly supports $R 2$ in the aggregate than the now-dissenting faction supports R3 in the aggregate. However, given the default pressures on Justices to vote sincerely, perhaps we might reasonably assume that a Justice will engage in unilateral strategic maneuvering only if the issue or outcome really matters to him. If so, we might reasonably assume that when such maneuvering occurs, the resulting coalition does roughly reflect the Justices' aggregate intensities of judgment. Even so, perhaps counterintuitively, the weighted-intensity model provides a firmer foundation for bilateral than unilateral strategic voting.

Acceptance of intensity weighting would provide further reason to downplay the strength of the commodification objection to vote trading, because it provides an alternative - and innocuous - "expressive" explanation of the practice. As discussed previously, one might plausibly fear that an important ideal of adjudication would be undermined if judgments were viewed as marketable commodi- 
ties. ${ }^{198}$ But consider the expressive difference between these two explanations: (1) "Five of us Justices really think the criminal defendant should win, but the Court hereby rules against her because one of us sacrificed this case in order to secure a better decision in another one;" and (2) "Five of us Justices really think the criminal defendant should win, but the Court hereby rules against her because those five are both unsure and ambivalent, and the other four Justices are certain that she should clearly lose." While the former explanation of the defendant's loss sounds unfocused and somewhat arbitrary, the latter explanation sounds both casefocused and reasoned. If vote trading comes to be perceived as a means of assessing comparative intensities in individual cases rather than merely as a means for improving rule packages across cases, any fear that trading will impute undesirable market norms into the adjudicatory process might largely dissipate.

My point here is not so much to defend vote trading outright because of its usefulness in assessing comparative intensities of judgment. Rather, I mean merely to question any simplistic application of the pure redundancy model to prohibit this strategic practice. The intuitive notion that vote trading undermines the accuracy of collective decisions by violating the sacrosanct-majority principle (and perhaps other extended principles as well) rests on an undefended premise that intensity should not count. At the very least, before strategic voting is rejected on this basis, the long-standing debate about intensity-weighting in the legislative arena must be reformulated and engaged in the judicial arena.

\section{Accuracy Through Deliberative Reasoning}

This "deliberative reasoning" model builds on the assumption that redundancy enhances accuracy. This model employs the familiar practice of equally weighting voting, but adds a new premise: that improving the process of collegial deliberation will enhance the accuracy of individual and hence group decisionmaking. The model thus provides a teleological argument in favor of strategic behavior that enhances deliberative reasoning and against strategic behavior antithetical to such reasoning.

As explained earlier, collegial deliberation can influence and improve Justices' decisionmaking, whether judgments are viewed as largely autonomously or collectively derived. ${ }^{199}$ One can plausibly

199. See supra notes $40-43$ and accompanying text. 
link the contribution of deliberation to the culture and environment within which deliberation takes place. ${ }^{200}$ To the extent a Justice feels well-treated and respected by his colleagues, he may be more open to engaging in dialogue, hearing new ideas, carefully considering well-founded criticisms, and perhaps viewing the entire reasoning process as collective rather than individualistic.

When Justices strategically deviate from their own sincere views in deference to their colleagues, they help to promote an internal culture of congeniality that enables collegial deliberation to flourish. For example, a general practice of minor accommodation, of reciprocal "going-along" voting, might facilitate feelings of good will which then promotes decisionmaking accuracy through improved deliberation. ${ }^{201}$

Of course, there is a tradeoff: long-run improvements in the deliberative process are purchased at the cost of deviations from immediate accuracy. One plausible balance would permit Justices to deviate from their sincere views only in minor degrees; thus, for example, unilateral acts of strategic voting to build coalitions through mutual deference would generally be permitted.202

While the teleology of deliberative reasoning thus might welcome strategic maneuvers that reinforce cooperative and intellectual engagement, the same teleology argues against strategic maneuvers whose effect or spirit foils the deliberative enterprise. On this basis, one might challenge explicit vote trading in various respects.

First, one might worry that, as vote trading becomes widely accepted, this means of deciding cases might come to dominate. Perhaps a Justice would spend less time trying to persuade his colleagues to see things his way in the Instant Case if he instead could try to circumvent any opposition through trading. I doubt this would have any more than a marginal effect on the quantity of

200. Of course, a cordial working environment might be desirable for purely social reasons. But I do not consider here the propriety of strategic behavior designed to maintain an amicable environment for its own sake, any more than to secure other personal agendas for their own sakes. See supra note 46.

201. See, e.g., Wald, supra note 101, at 524 ("Colleagues who are perennially annoyed and irritated with one another have difficulty listening respectfully and openmindedly to each other; they have little incentive to seek a middle ground."); id. at 527 (concluding that judges "can do much to keep personal friction to a minimum," including avoiding unnecessary dissents); cf. Shapiro, supra note 47, at 743 n.54 ("[I]t is well understood that the interests of courtesy (and reciprocity) call for a certain amount of deference.").

202. See, e.g., Shapiro, supra note 47. 
deliberation, since persuasion is always better than dealmaking. ${ }^{203}$ But, if persuasion is even theoretically unnecessary, perhaps the character or zeal of deliberative engagement will be subtly impaired. A norm against vote trading might then be instrumentally designed to "force" deliberation that might otherwise not occur.

Second, a regime in which explicit vote trading is commonplace might engender an atmosphere of conflict and distrust rather than cooperation and reciprocity. In the vote-trading exemplar, Justices Wapner and Judy might view each other as respectfully accommodating each other's views in one of the two cases, thus creating an atmosphere of mutual respect. At the same time, however, (assuming their colleagues detect the trade) Justices Wapner and Judy would likely anger their four erstwhile partners in their sacrificed case. Each of these partners might feel forsaken; she loses a case she thought she was about to win, knowing that she was not "consulted," let alone convinced, and that none of her like-minded colleagues was truly persuaded to abandon her position.

Relatedly, colleagues might view vote-trading Justices as trying to enhance their comparative power in a given case, since as indicated previously, trading operates to give extra weight to the traders' votes in their acquired cases (though reduced weight in their sacrificed cases). ${ }^{204}$ This perception might reinforce a competitive rather than collaborative spirit.

Thus the teleology of deliberative reasoning provides a defense for some accommodationist strategic maneuvers, but provides some basis for opposing explicit vote trading. Its implications for other strategic maneuvers are somewhat less clear. Tacit trading, whereby one Justice joins an author's circulated opinion quickly and uncritically notwithstanding sincere reservations in the hope that the author will later reciprocate on another case, still operates in effect to trade votes across cases. Nevertheless, because the affront to the nontrading Justices is both more subtle and difficult to detect, it may not appreciably threaten a commitment to collaborative discourse. Similarly, unilateral gambits such as the Craig hypo-

203. Both means of securing victories in the Instant Case, persuasion and trade negotiation, take time and energy. When successful, however, persuasion leads to a complete victory and negotiation leads to victory at the cost of a sacrificed case elsewhere.

204. Cf. Posner, supra note 4, at 125-26 (referring to vote trading as "powermaximizing," though in the course of making a different claim). This point highlights the ways in which various teleological arguments interconnect. If the Justices viewed intensityweighting as a proper aggregation mechanism for promoting accuracy, see supra section III.B.3, then they would not likely view vote trading as "power-maximizing" in any derogatory sense. 
thetical might be difficult for colleagues to detect. In any event, such maneuvers are more easily perceived as accommodating and deferential even though they are not actually so motivated. Where one draws the line, therefore, turns on one's nuanced perspective of both the importance and the delicacy of an ongoing commitment to the enterprise of collaborative decisionmaking.

\section{Moderation and Stability Through a Competitive Equilibrium}

This model, unlike the previous two, does not presume any conception of decisionmaking accuracy whose attainment is improved through redundancy of views (whether equally or differentially weighted). It merely acknowledges that different judges embrace different jurisprudential paradigms, and hence different substantive first principles and methodologies. Leaving aside any aspiration of ultimate "accuracy," multiplicity can still serve a valuable purpose: ensuring some moderation and stability of legal doctrine by generating a competitive equilibrium among Justices with opposing views. Justices will push and pull one another, each trying to move his colleagues toward his sincere position. Oppositional forces will generate collective decisions that are, by and large, moderate and stable. They will likely be moderate - in the sense of approximating the sincere views of the middle of the spectrum of views on the Court ${ }^{205}$ - because they will tend to be controlled by the median Justice. $^{206}$ They will also tend to be reasonably stable. Periodically, Justices may change their sincere views, or be replaced by others with different views. But the overall destabilizing effect of belief or personnel changes is muted by multiplicity, precisely because individual position shifts will not necessarily translate into collective shifts. Thus multimembership might be viewed as serving a centralizing and stabilizing function, even assuming away any effort to converge on a uniquely "best" outcome.

All forms of strategic voting threaten to disrupt the competitive equilibrium created by multiple sincere voters, leading to greater radicalization and instability of legal doctrine. One might plausibly argue, however, that explicit or tacit vote trading poses an appreciably greater threat than do unilateral maneuvers, and for this reason vote trading alone is improper. The argument runs as follows.

205. The more the range of views represented is skewed as compared to the universe of possible positions, the less "moderate" the middle will be appear. Many would maintain that both the Warren and Rehnquist Courts were skewed in this sense, although in different directions.

206. See supra note 65 and accompanying text. 
First consider the effect of both form-driven and unilateral content-driven strategic maneuvers on the moderation of collective outcomes. As explained earlier, in theory both of these types of maneuvers might lead to significant shifts away from the median sincere position toward either extreme wing. ${ }^{207}$ In other words, depending on relative conviction levels (as to both the importance of coalition building and the merits), unilateral maneuvering could generate many more "outlier" outcomes than would sincere voting. However, observers have noted that most identifiable maneuvers appear actually to involve marginal factions shifting, if not toward the median, then at least not in a markedly extreme direction. ${ }^{208}$ Perhaps the best explanation - one consistent with the "attitudinal model" 209 - is that Justices' judgments are quite ideologically influenced; ideological commitments tend to dominate over institutional concerns, and they also limit the range of favorable contentbased maneuvers. ${ }^{210}$ If this is so, then not surprisingly unilateral maneuvers would tend to generate substantively moderate outcomes.

In comparison, one might worry that bilateral vote trading would "marginalize" collective decisionmaking by moving more outcomes towards an outlier rather than median position. It is theoretically easier for an outlier faction to draw a more median faction to it, simply by trading the median faction a victory in some Other Case.211 But this concern can easily be exaggerated. The most likely trades will be those in which a Justice moves the Court's position to one that already enjoys strong-but-minority sincere sup-

207. See supra notes $66-68 \& 72$ and accompanying text (discussing form-driven shifts); supra notes $90-91$ and accompanying text (discussing content-driven shifts).

208. Recall that no single Justice can, by insincerely positioning himself further out on a wing, move the median of the Court that controls the disposition and (usually) the precedent. See supra note 88 . In this respect collegial adjudication is unlike, say, collegial judging of an Olympic diving event where the collective output is determined by a numerical mean, and therefore an outlier judge can unilaterally shift the mean by registering an extremely high or extremely low score (which is why the highest and lowest scores are conventionally disregarded in calculating the mean). Rather, a single Justice can shift the Court's collective output only through at least some degree of convergence with other Justice's positions. No single Justice can take the Court in a direction lacking substantial support.

209. See supra note 3 and accompanying text.

210. See supra note 68.

211. Without trading, a median faction would be willing to move toward the margin only if the perceived error of the suboptimal rule in the Instant Case were small, in comparison to the institutional gains or the substantive gain from forestalling an ever worse merits outcome. But with trading, a median faction can be encouraged to move toward the margin even if the perceived error of the suboptimal rule in the Instant Case is large - so long as in return the faction acquires a concession in the Other Case that cures an even larger perceived error. 
port (as in the vote-trading exemplar). ${ }^{212}$ While perhaps vote trades might (more frequently than unilateral maneuvers) move the Court away from its sincere median position, trading would still tend to generate outcomes comfortably far from radical extremes. Moreover, the fact that a trading Justice must publicly support (and thus endure potential criticism for) what she believes is a suboptimal rule in the sacrificed case will likely restrain her from straying too far from her core set of legal principles. ${ }^{213}$ As with unilateral maneuvers, then, it may well be that vote trading's theoretical bark is worse than its actual bite with respect to marginalization of collective outcomes.

A related concern is that, even if individual strategically shaped decisions remain within a reasonable distance of the median position, doctrine will develop erratically because the Court will occasionally flip-flop back and forth on the same basic issue from one side of the median to the other. This would most likely occur if the Court is close to evenly divided on the issue, because then a single trade might switch the collective result. For example, a conservative majority might control most Fourth Amendment decisions 5-4, but periodically the liberal faction would acquire control over a Fourth Amendment case via a vote trade sacrificing some other case to the conservatives. Such oscillations would depend on the mutually beneficial trades that happen to be available at the different points in time given the Court's ever-changing docket.214 I think this is a reasonable concern, though the force of the objection is muted somewhat by the doctrine of stare decisis, which - if taken seriously - should act as a brake on Justices' willingness to engage in trades that would lead to disconcerting vacillations. ${ }^{215}$

212. See supra note 178 (describing a median-promoting vote trade). In contrast, it would be quite difficult for a single strategic-minded Justice to generate support for a truly idiosyncratic outcome. She would have to negotiate a trade with at least four of her colleagues and offer each a concession of substantial value in order to convince them to support her position.

213. See Stearns, supra note 163, at 1349-50 (arguing that because opinion publication subjects judges to potential criticism for failure to abide by their own stated principles, "written opinions discourage ... vote trades").

214. As explained earlier, such oscillations would not be readily predictable even by savvy Court watchers, given the difficulty of discerning each Justice's MPE assessment over the range of cases available for trade. See supra note 130 and accompanying text.

215. More technically, the relational judgment criterion of consistency should influence the MPE assessment of any Justice considering whether to trade away her vote in the Instant Case. The greater the break with the pattern of existing precedent, the greater the MPE of the proposed rule and the more reluctant she should be to accept the terms of the trade.

Beyond the norm of consistency, fear of being criticized for flip-flopping might dissuade Justices from engaging in such strategic behavior. See Scalia, supra note 75 , at 42 (stating that Justices "cannot, without risk of public embarrassment, meander back and forth - today providing the fifth vote for a disposition that rests upon one theory of law, and tomorrow 
And it is worth noting that the same theoretical propensity for periodic flip-flopping inheres in legislative logrolling, given everchanging bargaining opportunities as the agenda fluctuates from year to year. In practice, however, one finds more stability and continuity than this concern might predict, at least on issues of major concern. Again the distinction between vote trading and other forms of strategic behavior may be one of degree, not kind.

Perhaps a more realistic concern is not so much ongoing vacillation within discrete realms of law, but a continual imbalance of judicial influence over discrete realms. Suppose one group of Justices has relatively strong convictions about free speech issues but weak convictions about antitrust issues, and a second group of Justices holds the opposite priorities. Vote trading would allow the former group, in general, to dictate free speech doctrine and the latter group, in general, to dictate antitrust doctrine. The development of each doctrine could thus diverge in a sustained way from the equilibrium position of the entire Court with respect to that particular issue.

Whether such a prospect is troubling, of course, is a matter of perspective and degree. Even leaving aside the rejoinder developed earlier that such divergence would reflect a plausible intensity-based measurement of "group accuracy,"216 would disproportionate factional influence over discrete issues be all that unprecedented? For many different reasons (ranging from deference to a colleague's expertise to saving one's resources for higherreturn cases), collegial judges sometimes permit one or a few members to assert disproportionate control over particular doctrines. ${ }^{217}$

In the end it is undeniable that, as compared to a norm of sincere voting, all forms of strategic behavior can (though they need not) move the collective outcome away from the median sincere position in the Instant Case and might generate erratic vacillations around that median over a series of cases. And explicit or tacit vote

providing the fifth vote for a disposition that presumes the opposite"). Of course, if vote trading became an accepted convention, then the likelihood and bite of such criticism would dissipate.

216. See supra section III.B.3.

217. See supra note 190. Individual judges have often asserted disproportionate influence over certain legal issues on their courts. For examples, see Stephen M. Bainbridge, Insider Trading Regulation: The Path Dependent Choice Between Property Rights and Securities Fraud, 52 SMU L. REv. (forthcoming 1999) (noting the "widely shared assumption that Justice Powell received substantial deference from his colleagues" with respect to the development of securities law); Margaret V. Sachs, Judge Friendly and the Law of Securities Regulation: The Creation of a Judicial Reputation, 50 SMU L. Rev. 777 (1997) (exploring Judge Friendly's disproportionate influence over his appellate court and the nation with respect to the development of securities law). 
trading theoretically poses a greater threat than do unilateral maneuvers, because the collective outcome bears even less of a necessary connection to the pattern of sincere votes on the specific issue in question. But whether these concerns are sufficient to justify a norm against strategic voting - particularly one directly uniquely at vote trading - is certainly not obvious.

\section{CONCLUSION}

"The Court is something of a paradox - it is at once the whole and its constituent parts. The very words 'the Court' mean simultaneously the entity and its members." 218 Appreciation of this paradox is reflected in an exciting explosion of political science scholarship modelling judicial behavior, scholarship that both predicts and tests for various forms of strategic or sophisticated conduct, and also offers new conceptualizations of the relationship between individual judges and their multimember courts. In particular, there is growing recognition that judicial behavior is not shaped merely by ideological attitudes and conceptions of legal reasoning, but also by formal institutional structures and informal role commitments. ${ }^{219}$ The question is not whether judges act in strategic or sophisticated ways, meaning whether they consider the consequences of their choices in light of the potential behavior of others. The question, rather, is what institutional commitments and conceptions shape and constrain judges' preferences and goals as they interact with colleagues to construct decisions of the court. In particular,

[B]argaining among the Justices is not merely a function of preferences plus an awareness of interactive effects; it is also an activity that is constituted by an evolving set of normative institutional perspectives. Because of these sorts of institutional effects the Justices internalize an understanding of whether such behavior is to be considered professional, as well as an understanding of what forms of bargaining are acceptable ....220

218. William J. Brennan, Jr., In Defense of Dissents, 37 Hastings L.J. 427, 432 (1986).

219. See Howard Gillman \& Cornell W. Clayton, Beyond Judicial Attitudes: Institutional Approaches to Supreme Court Decision-Making, in SuPreme Court Decision-Making, supra note 36, at 1,1-7 (explaining recent efforts to supplement the "attitudinal model" with more institutional approaches).

My inquiry about strategic voting has taken as given many existing formal and informal rules, e.g., deliberation, majoritarian decisionmaking, no individual abstention vote, no collective impasse default rule, and the influence of coalition size on precedential weight. Modifying these and similar rules would generate somewhat different judicial behavior and perhaps different normative questions.

220. Gillman, supra note 36 , at 75-76. 
One apparent "rule of the game"221 of collegial judging is that, while certain forms of output-focused strategic behavior are accepted (even encouraged) and others are quietly tolerated, explicit vote trading is disallowed. In theory, this observable but unwritten code of conduct might reflect a widespread judgment that, in the long term, vote trading is a counterproductive strategy for goaloriented judges on collegial courts. ${ }^{222}$ My strong sense, however, is that judges (and scholars) believe vote trading is wrong, not just unwise. But why?

My conclusion here is that the answer is more complicated than initial intuitions might suggest. While vote trading and other strategic maneuvers can plausibly be viewed as furthering legitimate judicial objectives, I have sketched a number of objections suggesting that vote trading nevertheless constitutes improper judicial behavior. But different objections rest on very distinct foundational assumptions about the nature and purpose of collegial adjudication. Moreover, some (though not all) objections logically entail that certain accepted strategic practices should be equally disapproved as well. Finally, some objections apply to vote trading or other maneuvers only in some contexts but not others, nuances not reflected in current practice. My hope is that this inquiry will stimulate deeper reflection about the "paradox" of collegial adjudication, and perhaps assist judges in developing a more refined understanding of the norms of their profession.

221. See supra note 11 and accompanying text.

222. Cf. Gillman, supra note 36 , at 71-72 (when discussing sophisticated rather than peerstrategic behavior, noting that perhaps "the course of action that might best maximize the interests of the Justices in the long run would be to act in a way that appeared principled rather than strategic"). 